
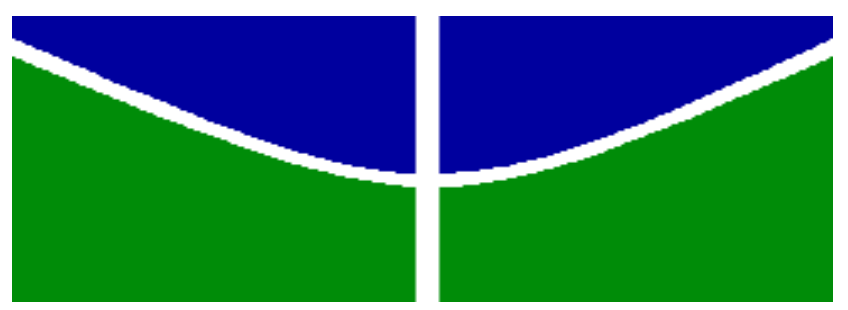

UNIVERSIDADE DE BRASÍLIA

FACULDADE DE EDUCAÇÃO

PROGRAMA DE PÓS-GRADUAÇÃO EM EDUCAÇÃO

LINHA DE PESQUISA: EDUCAÇÃO, TECNOLOGIAS E COMUNICAÇÃO

ESTUDANTES DO CURSO DE PEDAGOGIA A DISTÂNCIA (FE/ UnB - UAB): DAS SUAS TRAJETÓRIAS ÀS PERSPECTIVAS DE LONGEVIDADE ESCOLAR

BEATRIZ HELENA PINHO SILVA

ORIENTADOR: PROF. DR. CARLOS ALBERTO LOPES DE SOUSA

BRASÍLIA - DF 


\title{
ESTUDANTES DO CURSO DE PEDAGOGIA A DISTÂNCIA (FE/ UnB - UAB): DAS SUAS TRAJETÓRIAS ÀS PERSPECTIVAS DE LONGEVIDADE ESCOLAR
}

\author{
BEATRIZ HELENA PINHO SILVA
}

Dissertação de mestrado apresentada à Faculdade de Educação da Universidade de Brasília como requisito à obtenção do título de Mestre, sob a orientação do Professor Dr. Carlos Alberto Lopes de Sousa.

BRASÍLIA - DF 


\section{BANCA AVALIADORA}

Prof. Dr. Carlos Alberto Lopes de Sousa (Presidente)

Prof $^{a}$ Dra $^{a}$ Raquel de Almeida Moraes (Membro Interno)

Prof. Dr. Carlos Ângelo de Meneses Sousa (Membro Externo)

Prof ${ }^{a}$ Dr. Gilberto Lacerda dos Santos 


\section{Agradecimentos}

A Deus, pelo dom da vida.

Ao meu orientador, Professor Doutor Carlos Alberto Lopes, pela paciência, atenção e constantes puxões de orelha.

A minha amada família, pelo incentivo, apoio e sacrifícios que fizeram para que eu alcançasse esse sonho, em especial aos meus pais, que me passaram valores para a construção de um mundo melhor e pela dedicação e esforço em oportunizar condições para que eu pudesse estudar. A minha vovó, que se faz presente nas minhas lembranças mais doces, alegrando constantemente o meu viver. A minha irmã Bárbara, por ser sempre um exemplo de esforço, integridade e dedicação para com os estudos.

Ao meu companheiro, André, que escolheu dividir seus dias comigo, pelo apoio e incentivo manifestado durante toda minha trajetória acadêmica, pelas aprendizagens que construímos juntos e também pela grandeza em compreender minha ausência e intolerância no decorrer desta produção.

À amada e doce Martita, que se mostrou amiga em constante escuta, me ajudando com opiniões sugestões, leituras, inúmeras ideias, sempre me incentivando a buscar mais. Ao amigo Cauan, com seu olhar de estatístico, me ajudando em momentos importantes. A todos os amigos que me cercaram com orações, palavras de estímulo, me incentivando e acreditando no meu potencial, em especial aos amigos Kalliane, Jennifer e Fabrício, companheiros de vida e de trajetória acadêmica.

A todos os colegas de trabalho da Escola Classe Setor P. Norte, em especial a Magda, que soube ser líder e amiga me ajudando e incentivando a estudar mesmo em meio a tantos afazeres.

Aos alunos de Carinhanha - Bahia -, que me ensinaram lições de humildade, em especial aos egressos do Curso de Pedagogia da Universidade de Brasília, turma UAB 2. Fica aqui o meu respeito, carinho e consideração por esses egressos, que me fizeram pensar e refletir sobre o significado e a dimensão do que a modalidade a distância representa para suas vidas. 
"Tenho consciência de ser autêntica e procuro superar todos os dias minha própria personalidade, despedaçando dentro de mim tudo que é velho e morto, pois lutar é palavra vibrante que levanta os fracos e determina os fortes. O importante é semear, produzir milhões de sorrisos de solidariedade e amizade.

Procuro semear otimismo e plantar sementes de paz e justiça.

Digo o que penso, com esperança.

Penso no que faço, com fé.

Faço o que devo fazer, com amor.

Eu me esforço para ser cada dia melhor, pois bondade também se aprende!

Mesmo quando tudo parece desabar, cabe a mim decidir entre rir ou chorar, ir ou ficar, desistir ou lutar; porque descobri, no caminho incerto da vida, que o mais importante é o decidir."

Cora Coralina

"Não senti distância na educação a distância".

Fala de um egresso de Carinhanha, a respeito da modalidade educativa. 


\section{RESUMO}

A pesquisa foi realizada no município de Carinhanha (BA), com estudantes do curso de Pedagogia da Universidade de Brasília - UnB - em consórcio com a Universidade Aberta do Brasil - UAB. Com o escopo qualitativo, partindo da análise de discurso crítica e seu princípio da reflexividade, o trabalho teve como foco analisar a trajetória dos estudantes da EAD, considerando as suas condições de vida no lugar onde vivem e as perspectivas de longevidade escolar. Para isso, foram aplicados 25 questionários e realizadas entrevistas com 07 sujeitos. O referencial metodológico utilizado foi a análise de discurso crítica (RESENDE; RAMALHO, 2013) e a sua divisão em três momentos de reflexão: discurso direto, discurso indireto e pressuposição. Para a análise dos dados recolhidos e a reflexão sobre os problemas que enfrentam os sujeitos na sua realidade social e na sua relação com a educação a distância foram utilizados, entre outros autores, Lahire (1997), Portes (2000), Lopes, Lisniowski e Jesus (2011), Brito (2013). Dentre os principais resultados alcançados, destacam-se a importância da educação à distância para o município de Carinhanha (BA), e o modo como as trajetórias dos estudantes foram influenciadas por esse modelo educativo, o qual foi visto de modo positivo por eles. Quanto aos problemas ligados às condições de vida daquela localidade, os dados mostram que os sujeitos tiveram uma trajetória difícil, enfrentando muitos problemas, muitos deles derivados de sua condição socioeconômica e de deficiências na educação básica. A questão de gênero surgiu durante a pesquisa de campo sendo uma categoria que foi tratada no escopo do trabalho, pois faz parte da trajetória desses sujeitos, que são em sua maioria do sexo feminino. Observou-se que, em Carinhanha, a modalidade de educação a distância é viável, mesmo com uma estrutura que requer ainda melhorias, reformas e ações para que possa oferecer melhor atendimento aos esudantes. Apesar de tais problemas, a modalidade da EAD obteve êxito perante aquela comunidade, que continua tendo uma visão positiva da Universidade de Brasília. Dificuldades se mostraram presentes na realidade dos egressos, desde a falta de compreensão quanto à dimensão das estruturas sociopolíticas e opressoras que os envolvem as estruturas acadêmicas existentes. O diploma adquirido pelos egressos é visto por eles como uma conquista pessoal, sinal de reconhecimento vinculado à sua própria capacidade e dedicação, sendo um objeto de culto. $\mathrm{O}$ egresso tem o sentimento e a crença de que é por meio da constância da formação e por meio da longevidade escolar que se obtém o sucesso profissional e importância em outros setores da vida.

Palavras-chave: Educação a distância. Universidade Aberta do Brasil. Pedagogia. Trajetória. Longevidade escolar. 


\begin{abstract}
The survey was conducted in the municipality of Carinhanha (BA), with students from the Faculty of Education at the University of Brasilia - UNB - in partnership with the Open University of Brazil - UAB. With the qualitative scope, based on the critical discourse analysis and its principle of reflexivity, the work focused on analyzing the trajectory of the students of distance education, considering their living conditions in the place where they live and the prospects for extended learning. For this, we applied 25 questionnaires and interviews with 07 subjects. The methodological framework used was the analysis of critical discourse (RESENDE; RAMALHO, 2013) and its division into three moments of reflection: direct speech, indirect speech and assumption. To analyze the collected data and the reflection on the problems facing the subjects in their social reality and its relation to the distance were used, among others, Lahire (1997), Portes (2000), Lopes, and Lisniowski Jesus (2011), Brito (2013). Among the main results, it highlights the importance of distance education for the city of Carinhanha (BA), and how the trajectories of the students were influenced by this educational model, which was seen positively by them. As for the problems related to living conditions that locality, the data show that the subjects had a difficult path, facing many problems, many of them derived from their socioeconomic status and deficiencies in basic education. The gender issue arose during the fieldwork being a category that has been treated in the scope of work, as part of the trajectory of these individuals, who are mostly female. It was observed that in Carinhanha, the distance education mode is feasible, even with a structure that still requires improvements, reforms and actions so you can offer better service to estudantes. Despite such problems, the mode was successful against that community, which continues to have a positive view of the University of Brasilia. Difficulties proved present in the reality of graduates from the lack of understanding about the extent of socio-political and oppressive structures that involve existing academic structures. The diploma acquired by the students is seen by them as a personal achievement, recognition signal linked to their own ability and dedication, being an object of worship. The graduate has the feeling and the belief that it is through constant training and through extended learning obtained professional success and importance in other walks of life.
\end{abstract}

Keywords: Distance education. Open University of Brazil. Pedagogy. Trajectory. Extended learning. 


\section{LISTA DE TABELAS, GRÁFICOS E FIGURAS}

FIGURA 1:Mapa de Carinhanha - Bahia..........................................................................18

QUADRO 1: Dados socioeducacionais da cidade de Carinhanha - BA................................19

FIGURA 2: Painel econômico da cidade de Carinhanha - BA...............................................21

TABELA 1: Cursos ofertados no Polo de Carinhanha - BA.....................................................46

GRÁFICO 1: Faixa etária dos estudantes do curso de Pedagogia da turma

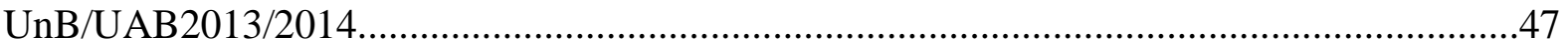

GRÁFICO 2: Renda dos estudantes do curso de Pedagogia da turma UnB/ UAB -

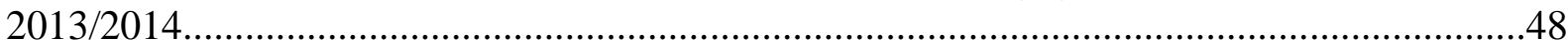

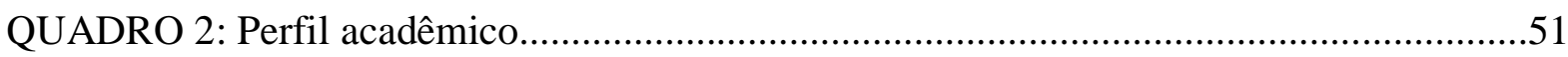

QUADRO 3: Influência ecônomica na formação do estudante...............................................54

QUADRO 4: QUADRO 4 - Perfil sociointeracional............................................................58

QUADRO 5: Desigualdade, pobreza e políticas sociais........................................................61

QUADRO 6: A inclusão tecnológica dos estudantes de Carinhanha - BA...............................64

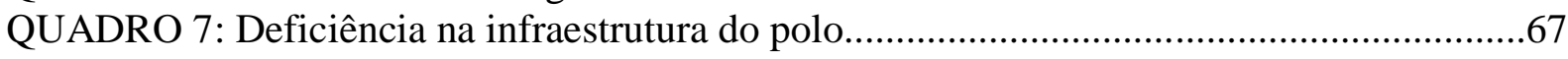

QUADRO 8: Percepção sociopolítica do viver em Carinhanha - BA.....................................70

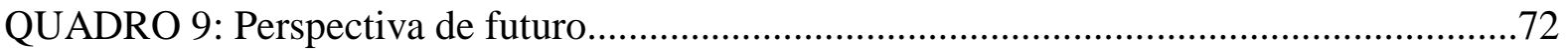

QUADRO 10: Sentido e significado que o egresso dá ao curso de Pedagogia e ao diploma da Universidade de Brasília. .78 


\section{SUMÁRIO}

1. INTRODUÇÃO.

\section{CAPÍTULO 2. CARINHANHA - BAHIA: CARACTERÍSTICAS HISTÓRICAS,

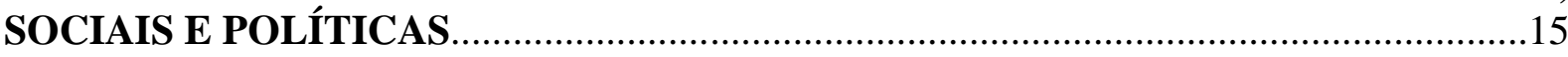

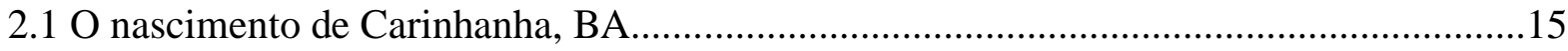

2.2 Município de Carinhanha - BA: Estrutura geopolítica................................................17

2.3 A questão econômica de Carinhanha - BA...............................................................20

\section{CAPÍTULO 3. A UNIVERSIDADE ABERTA DO BRASIL: PENSADA PARA OS

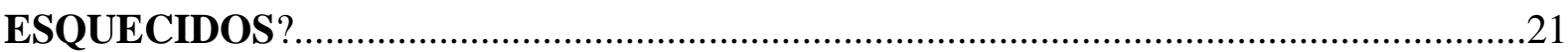

3.1 A educação a distância e o curso de Pedagogia oferecido pela UnB em Carinhanha BA

3.2 A Faculdade de Educação da Universidade de Brasília e a expansão do ensino superior

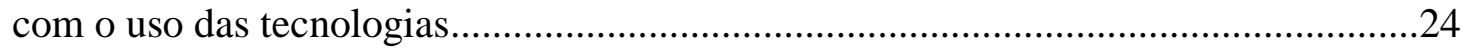

3.3 A expectativa da institucionalização da Universidade Aberta do Brasil.........................26

3.4 A modalidade a distância como inclusão social.................................................................

3.5 O sistema Universidade Aberta do Brasil e a questão da Educação a distância: Limites e possibilidades.

3.6 O percurso acadêmico do sujeito que estuda à distância: algumas reflexões sobre as trajetórias.

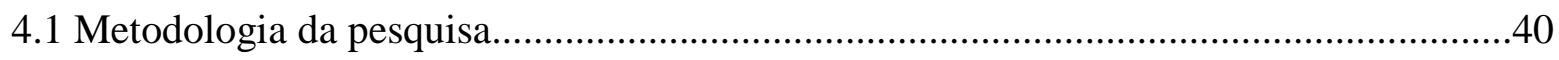

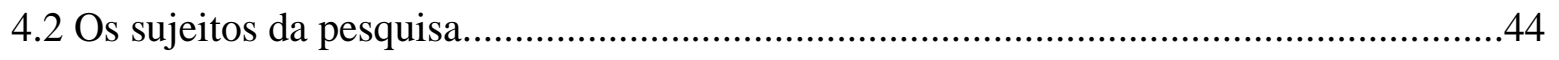

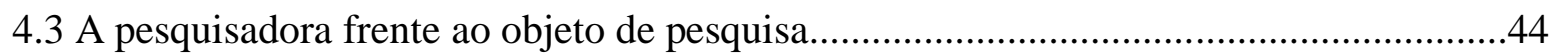




\section{CAPÍTULO 5. NAS TRILHAS DA EDUCAÇÃO SUPERIOR À DISTÂNCIA: A VOZ DOS EGRESSOS DA UnB /UAB NO MUNICÍPIO DE CARINHANHA -}

ВА

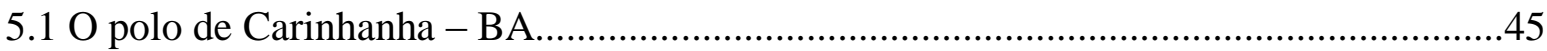

5.2 Resultados e discussão dos dados coletados na pesquisa..............................................47

5.3 Análise do perfil socioeconômico dos estudantes de Carinhanha - BA - do curso de Pedagogia $-\mathrm{Fe}-\mathrm{UnB} / \mathrm{UAB}$.

5.4 A análise de discurso crítica a partir do perfil dos estudantes.....................................49

5.5 Discussão do perfil acadêmico dos estudantes de Carinhanha - BA...............................50

5.6 A influência econômica na formação do estudante.......................................................52

5.7 Perfil sociointeracional: relacionamento com os colegas, tutores e professores durante o

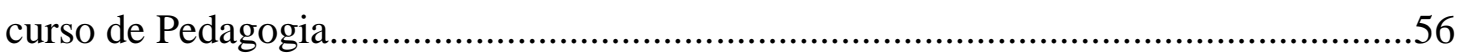

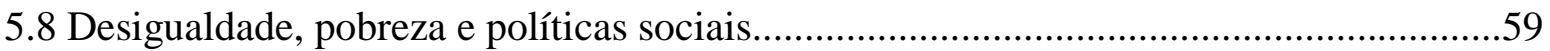

5.9 A inclusão tecnológica dos estudantes de Carinhanha - BA.........................................62

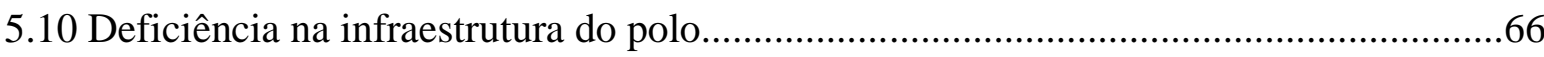

5.11 Percepção sociopolítica do viver em Carinhanha - BA...............................................69

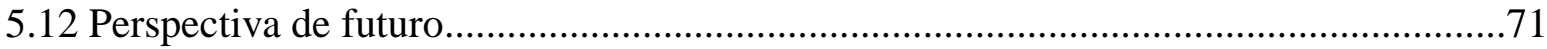

5.13 Educação a Distância e as questões de genero .........................................................74

5.14 Sentido e significado que o egresso dá ao curso de Pedagogia e ao diploma da

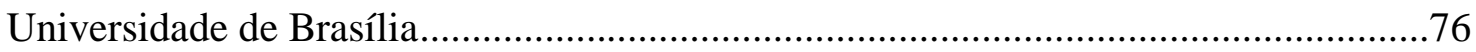

5.15 Recontextualização das vozes dos Sujeitos..............................................................82

CAPÍTULO 6. O DIPLOMA COMO EMPODERAMENTO .......................................86

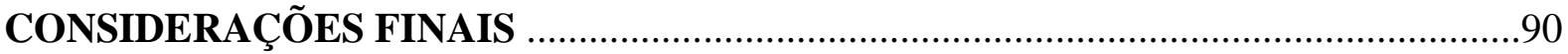

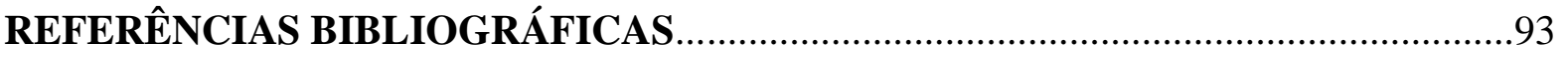


APÊNDICE 1 ROTEIRO PARA A ENTREVISTA NARRATIVA.....................100

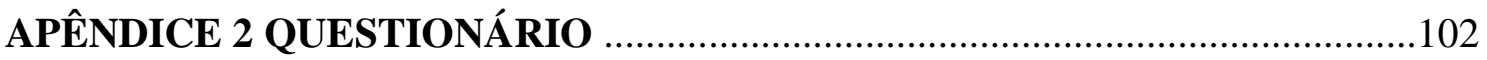

APÊNDICE 3 ROTEIRO ENTREVISTA NARRATIVA (2) ................................. 103

APÊNDICE 4 TERMO DE CONSENTIMENTO .............................................110

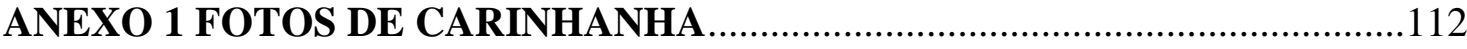




\section{1- INTRODUÇÃO}

A pesquisa apresentada nesta dissertação foi realizada junto a estudantes de Pedagogia do curso a distância da Universidade de Brasília, explorando as categorias das trajetórias e das perspectivas da longevidade escolar. O trabalho investiga também as questões das condições de vida em Carinhanha - Bahia -, localidade onde residem os participantes do presente estudo.

A escolha do tema deve-se a diversos fatores que fazem parte das vivências da pesquisadora. Ainda na graduação surgiu o interesse pelos estudantes de graduação em Pedagogia, do curso a distância em Carinhanha - BA, devido a um encontro casual com alguns alunos que estavam conhecendo o campus da Universidade de Brasília.

A pesquisadora também estudou a mesma temática na área da Educação durante a graduação, com pesquisa realizada no V Curso de Especialização Continuada e a Distância, oferecido pela FE/UnB. A formação do tutor foi o foco da monografia.

Além de realizar mestrado na área de Educação, Tecnologias e Comunicação, a pesquisadora também é especialista, pela Universidade Federal Fluminense, do Rio de Janeiro, em Gestão e Implementação de Cursos a distância. O curso foi realizado na modalidade a distância com encontros presenciais anuais.

Existem algumas pesquisas que tratam a respeito dos egressos do curso de Pedagogia. Podemos citar o trabalho de Kuhn (2012) que fala a respeito das práticas avaliativas de egressos do curso de pedagogia a distância, destacando as contribuições dessa modalidade, para a avaliação do docente. Santos (2009), realizou um estudo acerca da formação humana do profissional que é egresso do curso de pedagogia e cursou seu nível superior na modalidade a distância e investigou a influência dessa modalidade na prática docente. Em outro trabalho, Lopes, Lisniowski e Jesus (2011) traçam o perfil dos alunos que estudam à distância e os principais motivos de evasão.

A categoria das trajetórias também está inserida no contexto desta pesquisa e na mesma direção apontada por Portes (1993, p. 15), entendendo-se que "investigar quais têm sido as trajetórias escolares percorridas e as estratégias escolares utilizadas desde o início da escolaridade na luta por acesso a níveis mais avançados do sistema escolar”. Além disso, a necessidade e a constituição da modalidade de ensino à distância, que traz avanços para as camadas populares e precisam ser compreendidas conforme as condições de vida do lugar no

qual os estudantes vivem. É sabido que o processo educacional depende de fatores sociais que são singulares e podem segregar ou incluir, dependendo da complexidade situacional na qual 
o sujeito se encontra. Tratar da temática de desigualdades sociais, informacionais e educacionais é necessário para se conhecer o sujeito que estuda à distância e como se desenvolvem as trocas educacionais dentro do ambiente virtual de aprendizagem.

A modalidade à distância possui características andragógicas, ou seja, é voltada para adultos que enxergam nessa proposta educativa uma maneira de prosseguir seus estudos. Segundo Dias e Leite (2007), a ênfase da Universidade Aberta do Brasil - UAB está na expansão da educação superior com qualidade e promoção da inclusão social. Devido à inserção das Tecnologias de informação e comunicação - TICs, sustentáculo da UAB, os materiais e recursos são vastos, possibilitando a formação de um grande número de alunos.

Peters (2004) apresenta uma característica interessante dessa modalidade: o fato de que geralmente a Educação a Distância - EAD é voltada para os excluídos do sistema tradicional de ensino, principalmente do ensino superior - adultos com responsabilidades profissionais e familiares, que encontram na EAD uma possibilidade de aprendizagem. A educação a distância se propaga por meio das tecnologias com predomínio de uso da internet. A tecnologia é, portanto, algo inerente à modalidade, assim como o manuseio dos aparatos tecnológicos.

As seguintes questões nortearam esta pesquisa:

1- Como os formandos avaliam sua trajetória acadêmica realizada no curso de Pedagogia FE - UnB/UAB?

2- Quais as condições de vida dos egressos do curso de Pedagogia em Carinhanha- BA?

3- Que fatores favoreceram ou dificultaram a conclusão do curso na modalidade à distância?

4- Que perspectivas de longevidade escolar os egressos possuem? 
Os objetivos desta pesquisa são os seguintes:

\section{Objetivo geral:}

Analisar as trajetórias de estudantes do curso de Pedagogia - FE-UnB/UAB2, considerando as suas condições de vida no lugar e as perspectivas de longevidade escolar no contexto da realidade social no Município de Carinhanha - Bahia.

\section{Objetivos específicos:}

- Identificar, a partir das respostas e entrevistas dos egressos, a desigualdade, a pobreza e políticas sociais presentes em Carinhanha - BA.

- Levantar a perspectiva de longevidade escolar para o egresso do curso de Pedagogia FE/ UnB $-\mathrm{UAB}$

- Verificar a concepção dos egressos a respeito do diploma oferecido pela Universidade de Brasília e a importância do mesmo em suas vidas;

- Analisar a concepção que o egresso possui a respeito da educação a distância oferecida pela Universidade de Brasília;

- Descrever as trajetórias dos egressos ressaltando os fatores que favoreceram ou dificultaram a conclusão do curso na modalidade à distância.

O locus da pesquisa foio curso de Pedagogia oferecido pelo consórcio realizado entre a Universidade de Brasília - UnB e a Universidade Aberta do Brasil - UAB, em Carinhanha, Bahia. Os sujeitos da pesquisa foram alunos que ingressaram no último processo seletivo do polo de Carinhanha - BA turma UAB - 2 no ano de 2009.

Os cursos superiores a distância são permeados de valores e significados. Logo, a partir da trajetória de vida de quem vivencia essa modalidade e está inserido em um contexto de desigualdades, é possível identificar elementos extremamente importantes que explicam o papel desempenhado pela Universidade Aberta do Brasil e contribuem para a reflexão sobre o curso ofertado naquela localidade.

Conhecer as perspectivas futuras desses alunos beneficiará não só os estudos acadêmicos realizados nessa área, mas ajudará a entender quem é o egresso do curso de Pedagogia de Carinhanha - BA, da Universidade de Brasília. 


\section{CARINHANHA BAHIA: CARACTERÍSTICAS HISTÓRICAS, SOCIAIS E POLÍTICAS}

\subsection{O nascimento de Carinhanha, Bahia}

Carinhanha é um pequeno município brasileiro, localizado na região Nordeste do país. Trata-se de uma cidade pequena e interiorana que apresenta um clima amistoso e o respeito dos pequenos vilarejos que ainda cultivam costumes e tradições que se perderam com o passar do tempo nas grandes cidades.

De acordo com o Senhor José ${ }^{1}$, informante desta pesquisa, o primeiro bandeirante a chegar a Carinhanha, em 1711, foi Manuel Viana Nunes. O intuito do desbravador foi transformar o vilarejo em uma cidade. Na época, moravam ali índios e refugiados de Portugal, sendo estes últimos, segundo se comenta na região, pessoas que foram rejeitadas pela coroa portuguesa e viam no Brasil a oportunidade de recomeçar em uma terra nova.

Esses portugueses que aqui habitavam teriam vindo de Salvador e chegaram à localidade com o intuito de desbravar, habitar e retirar o sustento da nova terra. Além dos brancos portugueses, muitos negros oriundos de Salvador se mudaram para Carinhanha com os seus senhores. O interesse econômico mais imediato propiciado pelo lugarejo era a pesca no Rio São Francisco, que circunda a localidade.

Os negros vieram em grande número e constituem a grande massa da população atual, segundo o senhor José, dedicando-se até hoje à pesca, uma das principais atividades da cidade. A respeito do "achamento" ${ }^{2}$ de Carinhanha, Santos (2007 p. 9) acrescenta:

Sobre o descobrimento de Carinhanha, chegando aqui nesse território Manoel Nunes, em 1711, fundou logo um povoado. Construiu uma capela e escolheu como padroeiro o Glorioso São José. O povoado foi crescendo e se desenvolvendo, sendo Manoel Viana um dos homens de maior prestígio.

De acordo com os registros, o desbravador Viana foi um pioneiro de grande destaque na cidade. Souza (1981, p. 21) elenca as façanhas desse desbravador:

A violência aqui vem de longe. O bandeirante Manuel Nunes Viana chegou e foi atacando a aldeia dos índios Caiapós: matando, escravizando e cortando

\footnotetext{
${ }^{1}$ A pesquisadora conheceu o senhor José na segunda ida a Carinhanha. Ancião respeitado tinha muita sabedoria na fala, demonstrando amor e apego à cidade e muito conhecimento sobre a história de Carinhanha. $\mathrm{O}$ ancião foi apresentado à pesquisadora, pois dados sobre o nascimento e histórico de Carinhanha necessitavam ser buscados. 2 A palavra "achamento" foi utilizada para designar o termo utilizado para o dia em que Manuel Nunes Viana atracou no Porto de Carinhanha - BA.
} 
orelhas, como prova de suas façanhas de bandeirante. Sem a proteção dos missionários, acabaram fugindo daqui para a Serra do Ramalho.

A questão do extermínio dos índios se fez presente na colonização do Brasil de maneira muito forte. De acordo com Souza (1981, p. 25): “Temos resquícios atualmente da chacina que ocorreu não só com os índios, mas também com os negros e alguns europeus que vieram trabalhar no cultivo do café após a escravidão".

No caso de Carinhanha, muitos dos negros que vinham para serem escravizados desembarcavam nos portos do Rio de Janeiro e de Salvador, duas cidades privilegiadas quanto à acessibilidade marítima. Carinhanha, no entanto, se firmou como vilarejo que tinha como característica a exploração de riquezas naturais e a usurpação do legado dos índios que ali viviam, conforme aponta Santos (2007, p. 21):

\begin{abstract}
Originalmente, no local da sede de Sesmaria, habitava uma tribo dos índios Caiapós. Estes foram desalojados por Manuel Nunes Viana, que cumpria a função de foreiro de Antônio Guedes de Brito e tutor das filhas do finado Mestre de Campo. Esse recebeu da Coroa Portuguesa a missão de pacificar o São Francisco, vencendo os índios confederados e batendo os negros aquilombados.
\end{abstract}

Carinhanha abrigava muitos quilombos erguidos por negros oriundos de Salvador (SANTOS, 2007). Apesar da exploração e do extermínio dos negros e dos indígenas, a cidade cresceu e se firmou na época da colonização. Um dos motivos principais para esse desenvolvimento se deve ao fato de a região ter sido rica em minérios valiosos, como ouro e diamante, o que despertou a cobiça também em outros desbravadores, conforme destaca Santos (2007, p. 23):

\begin{abstract}
Manuel Viana entrou em conflito com os bandeirantes paulistas e liderou contra eles uma guerra que ficou conhecida como Guerra dos Emboabas, que perdurou anos. O conflito foi motivado pelo controle português das minas de ouro e diamantes, pela hegemonia do comércio regional em oposição aos bandeirantes paulistas, que reivindicaram o mesmo direito.
\end{abstract}

No entanto, seu legado terminou com uma morte também violenta: foi assassinado por um amigo. Após a morte do bandeirante, Carinhanha vivenciou a fase de coronelismo, e segundo Santos (2007, p. 39), "não restava mais dúvidas de que, em 1914, quem vai mandar em Carinhanha é o Coronel Antônio Porphirio Dias Andrade Filho, afilhado do presidente da província, José Joaquim Seabra”.

Esses coronéis exerciam o poder explorando todos os recursos que a cidade oferecia e formando verdadeiros impérios, utilizando a força de trabalho dos negros que ali chegavam, 
dos poucos índios que sobraram e dos demais moradores da localidade. E assim Carinhanha ingressou no ciclo do Coronelismo, que perdurou durante muito tempo e, segundo Santos (2007, p. 41), prevalece até hoje em muitas regiões brasileiras: "Os coronéis em Carinhanha sempre existiram, é que atualmente eles são eleitos pelo povo".

Sabemos, no entanto, que, mesmo em face de desigualdades, há uma Bahia que sempre lutou e continua lutando e resistindo à subjugação e às injustiças. São importantes, na sua história, os movimentos sociais que despertam e desenvolvem na população a sagacidade e a coragem. O estado da Bahia é uma referência na luta por justiça social, conforme apregoa Santos (2007, p. 34):

Quem olha para a história da Bahia, de forma superficial, só reconhecia naquele povo um povo festivo, acomodado, identificado apenas com danças folclóricas, com baianas típicas, com carnaval e samba. A história real revela uma Bahia discreta que organiza o povo pra luta nas Comunidades de Base, nos Sindicatos de trabalhadores; a Bahia dos movimentos de Consciência Negra, dos movimentos de mulheres, dos movimentos populares de arte e cultura.

Uma Bahia que quer e deseja a transformação e vê nos movimentos sociais uma forma de resistência e de luta por mudanças é o que tem sido buscado por muitos baianos. Para isso, além da necessidade de se observar como se dão as lutas cotidianas pela sobrevivência e pela modificação das condições sociais e culturais, é preciso atentar para os juízos de valor, os estigmas e os preconceitos que acompanham as visões tradicionais sobre os habitantes da região. Tais preconceitos precisam ser enfrentados e esclarecidos a fim de que se possa enxergar com maior profundidade as questões históricas, sociais e políticas que envolvem não apenas a Bahia, mas o Brasil como um todo.

\subsection{Município de Carinhanha - BA: Estrutura geopolítica}

Carinhanha é um município da Bahia que possui aproximadamente, de acordo com dados do IBGE - 2010, 28.380 habitantes, distribuídos numa área total de 2.737,183 km² e tendo como o bioma o Cerrado. Ainda de acordo com o IBGE, Carinhanha teve sua divisão territorial estabelecida em 2001 e, desde 2007, ficou definida a existência de dois Distritos: Carinhanha e Barra Parateca. 
FIGURA 1: Mapa de Carinhanha - Bahia

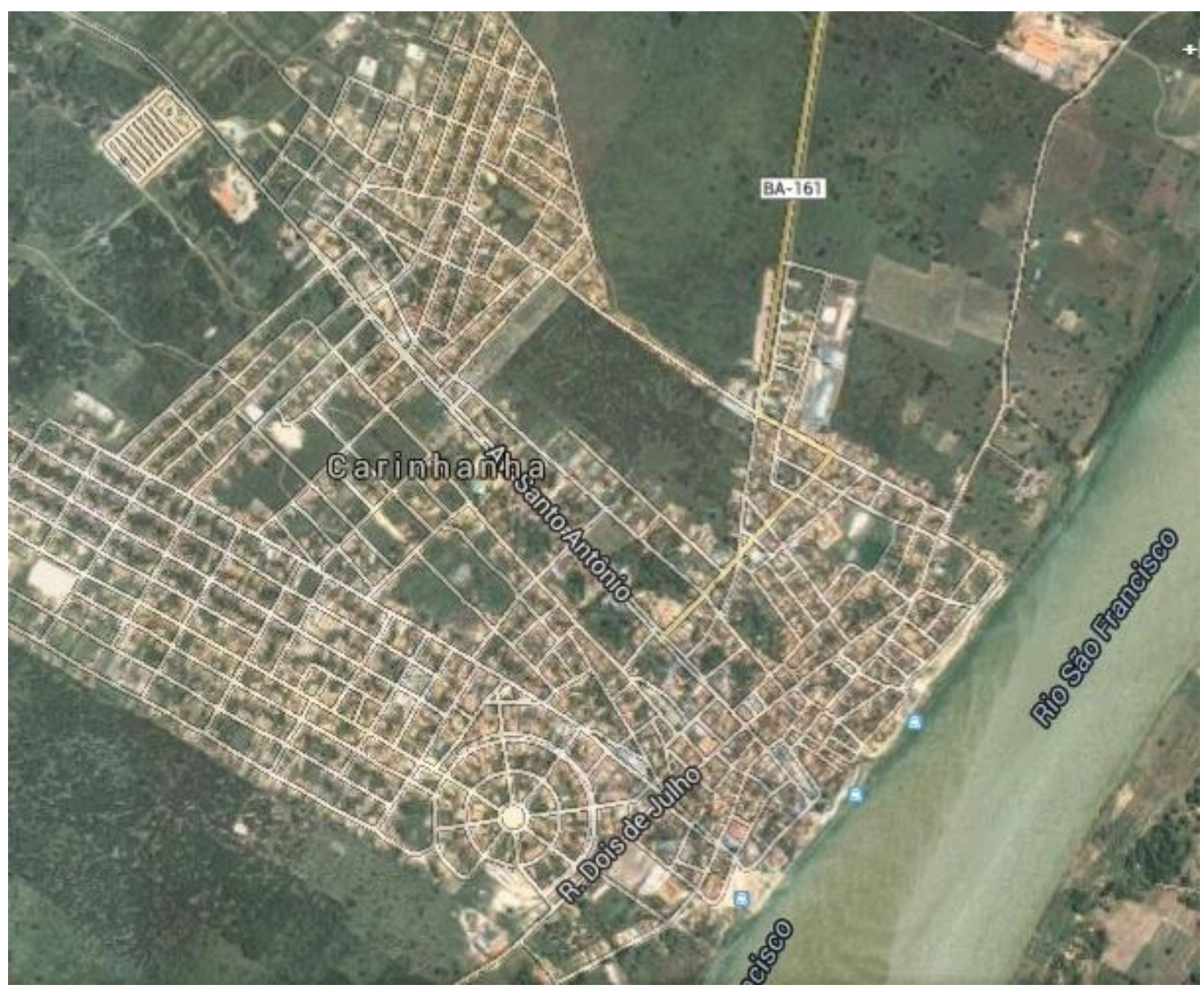

Fonte: www. googlemaps.com.br

O município de Carinhanha é cercado pelo Rio São Francisco e a maioria da população utiliza o rio para transporte, para a pesca e para o turismo, pois atrai visitantes das cidades próximas e também os vindos de longe, sendo muitos deles biólogos e pesquisadores de diversas áreas do conhecimento. 
QUADRO 1- Dados socioeducacionais da cidade de Carinhanha - BA

Índice de Desenvolvimento Humano Municipal - 2010 (IDHM 2010) 0,576

Matrícula - Ensino fundamental - 2012

6.014

Matrículas

Matrícula - Ensino médio - 2012

Matrículas

Pessoal ocupado total

Pessoas

PIB per capita a preços correntes - 2011

4.007,33 Reais

População residente

Pessoas

População residente - Homens

Pessoas

População residente - Mulheres

13.857

Pessoas

População residente alfabetizada

18.909

Pessoas

População residente que frequentava creche ou escola

Pessoas

População residente, religião católica apostólica romana

Pessoas

População residente, religião espírita

Pessoas

População residente, religião evangélica

3.775

Pessoas

Valor do rendimento nominal mediano mensal per capita dos domicílios particulares permanentes - Rural

Reais

Valor do rendimento nominal mediano mensal per capita dos domicílios particulares permanentes - Urbana

Reais

Valor do rendimento nominal médio mensal dos domicílios

particulares permanentes com rendimento domiciliar, por 703,63

Reais situação do domicílio - Rural 
Valor do rendimento nominal médio mensal dos domicílios

particulares permanentes com rendimento domiciliar,

Reais

por situação do domicílio - Urbana

Fonte: $\quad$ Site

do IBGE, 2014-disponível

em:

http://www.cidades.ibge.gov.br/xtras/temas.php?lang=\&codmun=290710\&idtema=16\&search=||s\%EDntesedas-informa\%E7\%F5es

2.3 A questão econômica de Carinhanha - BA

O município de Carinhanha atualmente tem a agropecuária como atividade mais lucrativa. Existem pequenos agricultores que cultivam frutas, legumes e verduras e vendem em Carinhanha e nas cidades próximas.

A pesca também faz parte da cultura de Carinhanha - BA. No entanto, o Rio São Francisco tem sofrido com a estiagem, e os níveis de água do rio estão cada vez mais baixos, o que reduz em muito a quantidade de peixes. Tal situação, segundo os próprios estudantes da cidade, tem se agravado nos últimos 10 anos, quando o clima começou a afetar a economia e a vida na região. $\mathrm{O}$ problema tem atraído a atenção de muitos pesquisadores e tem sido fonte de preocupação para os moradores da cidade.

Há também muitas agrovilas no município de Carinhaha. Nelas, os agricultores cultivam verduras, frutas e legumes para a venda. No entanto, de acordo com o gráfico do IBGE sobre o painel econômico da cidade, são outros setores da economia que têm crescido consideravelmente em época mais recente: os serviços e a indústria. 
FIGURA 2- Painel econômico da cidade de Carinhanha- BA

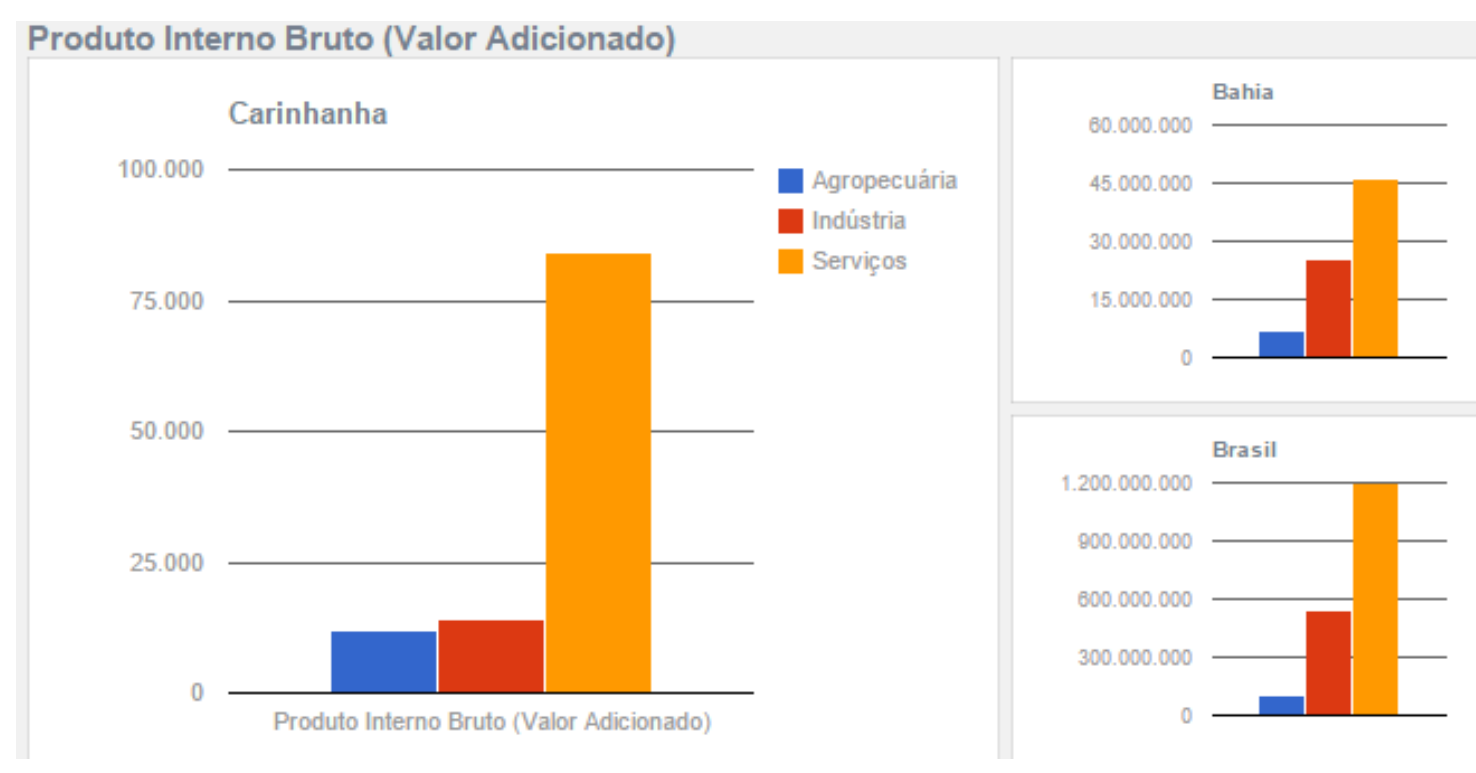

Fonte: http://cidades.ibge.gov.br/painel/economia.php?codmun=290710\&lang=_ES

Como se pode observar, a partir desses dados referentes à predominância do setor de serviços e da indústria, em comparação com o setor agropecuário, Carinhanha tem se adaptado aos novos tempos quanto às demandas socioeconômicas, o que a caracteriza como uma localidade de feição cada vez mais urbana.

\section{A UNIVERSIDADE ABERTA DO BRASIL: PENSADA PARA OS ESQUECIDOS?}

3.1 A educação a distância e o curso de Pedagogia oferecido pela UnB em Carinhanha

Oferecer cursos de formação universitária para profissionais que já atuam sem um nível superior, como é o caso de muitas cidades brasileiras, se mostra necessário e urgente em diversos aspectos. E, por várias razões, tal acesso ao ensino só se torna possível com o incremento e a implantação de programas educacionais que tem como base a educação a distância.

A educação a distância é uma modalidade educativa que, atualmente, tem sido realizada a partir da mediação possibilitada pelo uso das modernas tecnologias. Essa modalidade de educação surgiu da necessidade de democratização do acesso à educação, destacando-se o direcionamento de tal tipo de acesso ao ensino para as camadas populares. Com o surgimento das TICs (Tecnologias de Informação e Comunicação), essa modalidade tem ganhado espaço no cenário educacional brasileiro, especialmente por causa do imenso 
território e as dificuldades inerentes a esse fator, devido à grande distância existente entre os lugarejos mais afastados e os centros econômicos, políticos e culturais do país.

De acordo com Chaves (1999, p. 1), podemos definir a educação a distância da seguinte maneira:

O ensino que ocorre quando o ensinante e o aprendente estão separados (no tempo ou no espaço). No sentido que a expressão assume hoje, enfatiza-se mais a distância no espaço e propõe-se que ela seja contornada através do uso de tecnologias de telecomunicação e de transmissão de dados, voz e imagens (incluindo dinâmicas, isto é, televisão ou vídeo). Não é preciso ressaltar que todas essas tecnologias, hoje, convergem para o computador.

Com o advento do computador e da comunicação em rede essa modalidade atualmente é propagada em grande parte com o uso das tecnologias. No entanto, essa modalidade de ensino passou por diversas fases - relevantes para que ela atingisse o patamar dos dias de hoje. No que diz respeito ao seu histórico, a EAD passou por vários períodos. Diversos teóricos apresentam a história da EAD de formas diversas; a que utlizaremos neste trabalho é a conceituação histórica dividida por fases adotada por Gomes (2008, p. 28). São elas:

\footnotetext{
- A primeira ocorreu até a década de 1960; foi chamada de geração textual e utilizava somente textos impressos enviados pelos Correios.

- A segunda ocorreu entre as décadas de 1960 e 1980; foi chamada de geração analógica e utilizou como suporte os textos impressos complementados por recursos tecnológicos audiovisuais ${ }^{3}$.

- A terceira, e atual, é a geração digital; utiliza o suporte de recursos tecnológicos modernos, tais como as tecnologias de informação e comunicação e de fácil acesso às grandes redes de computadores, bem como à internet.
}

Essas fases foram propulsoras e estimuladoras para que essa modalidade conseguisse alcançar a importância que tem nos dias atuais. De acordo com essa periodicidade histórica, estamos vivenciando a terceira fase que se propaga por meio da das tecnologias, que atualmente avançam rapidamente e respondem aos anseios da sociedade, cada vez mais voltada para o uso de tais tecnologias. Nesse sentido, a EAD, demonstra ter se adaptado ao momento histórico atual e tem se mostrado um dos setores em que mais se observa a inovação e o aproveitamento das ferramentas digitais no cotidiano.

Nesse contexto, a Universidade de Brasília (UnB), juntamente com a Universidade Aberta do Brasil (UAB), oferece como estrutura o ambiente virtual de aprendizagem (AVA)

\footnotetext{
${ }^{3}$ Recursos tecnológicos audiovisuais: todo e qualquer recurso de imagem e sons utilizados na educação para ajudar no entendimento de um assunto, fixar a aprendizagem, motivar, estimular a participação em atividades etc. Podemos citar, como exemplos, o quadro-de-giz, a voz da pessoa que está ministrando uma aula, gravuras ou ilustrações, maquetes, televisão educativa, retroprojetor, fitas cassete, CD-Rom e computador (GOMES, 2008).
} 
para estabelecer suas trocas educativas de maneira colaborativa, utilizando a rede internet. Nesse ambiente, os estudantes interagem com diversas ferramentas tecnológicas presentes no ambiente virtual, como os fóruns de discussão, chats, wiks (construção textual colaborativa), vídeos, textos, livros virtuais e um grande número de ferramentas que podem ser utilizadas no espaço virtual.

As interações no ambiente virtual podem ser de maneira síncrona, que, segundo Gomes (2008, p. 31), “é a comunicação entre duas ou mais pessoas em tempo real. Neste caso, as pessoas precisam estar conectadas de alguma forma. Exemplos: no chat, no telefone ou na videoconferência".

Ou assíncrona que, também segundo Gomes (2008, p. 31),

Permite o debate de temas, com a inclusão de opiniões em qualquer tempo, não sendo necessário que os alunos estejam conectados simultaneamente, como na comunicação síncrona. Como exemplo, podemos citar correspondência, e-mail, aulas gravadas etc.

No caso da Universidade de Brasília em Carinhanha, a proposta de modelo pedagógica oferecida pelo curso preconiza momentos assíncronos e síncronos, e também encontros presenciais entre os alunos, professores e tutores, além do atendimento oferecido no polo de Carinhanha - BA pelo tutor presencial, profissional da educação responsável por auxiliar o aluno em seu percurso acadêmico.

A educação a distância pressupõe uma intensa relação entre os atores envolvidos para que haja uma aprendizagem verdadeiramente significativa. Segundo Gomes (2008, p. 28):

\footnotetext{
É fundamental que alunos, professores, tutores estejam integrados e "próximos", para que haja facilitação no processo de ensino-aprendizagem. Para isso, alguns fatores devem ser levados em consideração: o público-alvo do curso em EAD; a tecnologia utilizada para levar a informação; o grau de interação entre alunos, professores e tutores; as mediações pedagógicas.
}

Essa proximidade é relevante e se faz necessária. Logo, refletir acerca do modelo de proposta pedagógica, o público alvo, a tecnologia que mediatiza essa aprendizagem e o principal: a interação entre os atores desse processo (tutores, professores e alunos), que é importante para que haja crescimento pensando no aluno que se beneficiará com esse modelo educativo (GOMES, 2008). 
3.2 A Faculdade de Educação da Universidade de Brasília e a expansão do ensino superior com o uso das tecnologias

A Faculdade de Educação da Universidade de Brasília possui uma longa trajetória no que diz respeito à iniciativa de se democratizar o ensino por meio das tecnologias. Desde sua criação existem esforços em prol de uma educação tecnológica pautada no uso das TICs. Pontes (2009, p. 21) informa o modo como se deu o desenvolvimento da EAD na UnB:

\begin{abstract}
Nas suas iniciativas de abrir fronteiras na UnB na área das tecnologias educativas, a Faculdade de Educação criou sua habilitação em Tecnologia Educacional no curso de pedagogia (1975), contribuiu diretamente na criação do centro de Produção Cultural e Educativa - CPCE (1986), do centro de Educação Continuada e a Distância - CEAD (1988), e do centro de Informática educativa do Ensino Superior - CIES (1994). Além disso, institui no Mestrado em Educação a área de convergência em Tecnologias na Educação (1996) e a área de Educação e Comunicação, relacionada com a temática das NTIC, no doutorado iniciado em 2004.
\end{abstract}

Houve uma preocupação por parte da FE/UnB, em utilizar as tecnologias em prol de uma expansão educacional substancial. E isso propiciou seu crescimento beneficiado pelo compromisso de educadores que tinham o intuito de fortalecer cada vez mais a aprendizagem colaborativa focada no uso das tecnologias. Dado esse entusiasmo por parte de muitos educadores da FE/ UnB, nasce a rede CTAR (Comunidade de Trabalho e Aprendizagem em Rede) que segundo Pontes (2009, p. 22) tratava-se de uma "educação aberta, apoiada na pedagogia da autonomia exercida numa comunidade de trabalho e aprendizagem em rede, utlizando com propriedade as tecnologias de informação e comunicação".

Essa rede foi instituída com o intuito de se criar uma parceria sólida e forte formada por educadores de dentro e fora da FE-UnB a fim de fortalecer a aprendizagem a distância e formar pesquisadores que discutissem e disseminassem com propriedade essa modalidade, propiciando seu crescimento e expansão.

A FE da UnB sempre se articulou em prol de uma formação continuada por meio das tecnologias. Logo, fomentar cursos que ampliassem as oportunidades de aprendizagem do profissional que trabalha com EAD sempre esteve em pauta. Diante disso, destacamos o Curso de Especialização em Educação Continuada e a Distância, ${ }^{4}$ que faz parte da trajetória da FE-UnB e atendeu o seguinte público- alvo: profissionais que realizavam tutoria no Sistema

\footnotetext{
${ }^{4}$ Dados extraídos do site: http://www.fe.unb.br/catedraunescoead/areas/ensino/curso-de-especializacao/curso-deespecializacao-em-educacao-continuada-e-a-distancia.
} 
$\mathrm{UAB}$, Coordenadores de polos da UAB, professores de outras IES e funcionários da UnB e da CAPES envolvidos com atividades de Educação a Distância. Esse curso é oferecido pela Faculdade de Educação desde 2000 e já está em sua quinta versão e teve sua última oferta em 2011, ampliando as chances de aprendizagem dos profissionais que atuam nessa modalidade.

Dada essa realidade de ascensão, gradação e disseminação da educação tecnológica, a FE-UnB não demorou em aderir ao projeto da UAB, em 2007, no âmbito da formação de professores, conforme expõe Lopes, Lisniowski e Jesus (2011, p. 2): “A Faculdade de Educação iniciou a oferta do Curso de Pedagogia a distância no ano de 2007 e, a partir daí, possibilitou, por meio de processo seletivo, três entradas de alunos: a primeira em 2007, a segunda em 2009 e a terceira em 2011."

A iniciativa da FE-UnB foi uma resposta à necessidade de auxiliar na formação desses professores em diversos locais. Os dados quantitativos apontados por Lopes, Lisniowskie Jesus (2011, p. 2), demonstram como essa modalidade de ensino atingiu altos índices de alcance e aceitação dada à carência que o Brasil apresentava e ainda apresenta quanto ao acesso à educação superior:

\begin{abstract}
Na primeira oferta (UAB1), em 2007, ingressaram 135 alunos, sendo 50 no município de Alexânia, 35 em Alto Paraíso, ambos no Estado de Goiás, e 50 em Carinhanha, na Bahia. Em 2009, houve ampliação da oferta nesses Polos, além da abertura de novas vagas para alunos dos Polos de Águas Lindas e Cidade de Goiás, no Estado de Goiás. Ingressaram, nessa segunda oferta (UAB2), 205 alunos, 42 em Alexânia, 40 em Alto Paraíso, 41 em Carinhanha, 41 em Águas Lindas e 41 na Cidade de Goiás. Em 2011, com a UAB3, a oferta foi ampliada nos Polos de Alexânia e Cidade de Goiás, com 75 vagas em cada polo, o que possibilitou a entrada de 150 novos alunos, em um universo de 582 candidatos em Alexânia e 392 na Cidade de Goiás, numa proporção de, respectivamente, 7.76 e 5.23 alunos por vaga.
\end{abstract}

Estender o acesso desse ensino a fim de democratizar a educação superior tem sido a luta de educadores sérios e comprometidos com o trabalho que desenvolvem. Dado esse compromisso social, a UnB ampliou seu alcance ao participar do programa $\mathrm{UAB}$, que difunde e propaga um ensino que visa levar equidade educacional a diversos locais.

Devido a esse alcance, questionar e refletir acerca da educação oferecida é relevante e necessário. Sabemos que por mais que os cursos oferecidos pela UnB tenham qualidade, problemas poderão e podem surgir no desenvolvimento e expansão desse ensino. A FE da UnB não está isenta deles e terá de enfrentar as adversidades que poderão emergir na realidade brasileira, que por vezes se apresenta difícil, seja no âmbito social (no que diz respeito à realidade que os alunos enfrentam) ou no âmbito político-acadêmico (que trata dos 
credenciamentos e da qualidade da infraestrutura) que a UAB oferece para Universidades que aderem à sua política de expansão.

\subsection{A expectativa de institucionalização da Universidade Aberta do Brasil}

O Sistema Universidade Aberta do Brasil (UAB) foi criado em 2005 e oficializado pelo decreto $n^{\circ} 5.800$, de 8 junho de 2006. Tem como objetivos a democratização, a expansão e a interiorização da oferta de ensino superior público e gratuito no país. Trata-se de uma articulação entre as instituições de Ensino Superior e o polo de apoio presencial.

Segundo Dias e Leite (2007), o MEC não criou uma nova instituição de ensino, mas articulou as já existentes por meio de consórcios firmados com a UAB e a instituição de ensino superior. A ênfase da UAB está em programas voltados para a expansão da educação superior com qualidade e promoção de inclusão social. Devido à inserção das Tecnologias de informação e comunicação, sustentáculo da UAB, os materiais e recursos são inúmeros, possibilitando a formação de uma grande demanda de alunos.

Atualmente o sistema Universidade Aberta do Brasil, de acordo com o site da Capes ${ }^{5}$, conta com um quantitativo de 96 instituições de educação superior com 668 polos em consórcio com essas instituições, oferecendo cursos de licenciatura, bacharelado, especialização e mestrado profissional, contabilizando mais de 210 mil estudantes nos cursos de licenciatura, 24.207 no bacharelado, cerca de 7 mil no nível tecnólogo, 66 mil nas especializações, 21.176 para aperfeiçoamento e 2.800 no Mestrado Profissional em Matemática na Rede Nacional (Profmat). É um número alto e a tendência da EAD é crescer e atender a um contingente cada vez maior de pessoas, dada a grande extensão territorial que o Brasil tem e as constantes demandas educacionais.

Devido a essas carências, o governo federal viu a necessidade de investir na educação a distância, pois muitas pessoas não estudavam, ficando esquecidas do processo educacional por diversos motivos, e isso as excluía do mercado de trabalho, contribuindo para uma baixa qualificação acadêmica e profissional da população.

Aires (2004) comenta a respeito dessa necessidade, pois segundo a autora, a lógica excludente ainda é hegemônica e, no caso da EAD, trata-se de uma modalidade educativa que, além da equidade, objetiva a socialização e a democratização do conhecimento, sendo este um

\footnotetext{
${ }^{5}$ Dados quantitativos extraídos do site:

http://uab.capes.gov.br/index.php?option=com_wrapper\&view=wrapper\&Itemid=12
} 
dos pilares da UAB: democratizar o ensino, derrubando as barreiras geográficas por meio de uma educação sem fronteiras.

Diante de tal cenário, a educação a distância brasileira ganhou força e espaço. No entanto, discutirmos a qualidade da UAB se faz necessário, dado o atual contexto social em que a UAB se encontra. Ela foi criada com o intuito de expandir a educação superior do país, ampliando o acesso e a permanência do aluno, conforme aponta Brito (2013, p. 2), resgatando o momento histórico de criação dessa política:

\begin{abstract}
A UAB integra o conjunto de políticas públicas para a educação superior do Governo Lula da Silva (2003-2006 e 2007-2010), que procedeu a uma reforma universitária orquestrada pelo movimento de expansão de vagas e de interiorização do acesso como moeda de troca para que os investimentos em infraestrutura e em recursos humanos pudessem chegar às Instituições Federais de ensino superior.
\end{abstract}

A fim de que a UAB pudesse se estruturar e expandir, suprindo as carências existentes na educação superior, que se apresentavam emergenciais no Brasil, fora instituído um grupo de trabalho coordenado pelo Ministério da Educação e composto por representantes da Casa Civil da Presidência da República, da Secretaria - Geral da Presidência da República, do Ministério do Planejamento, Orçamento e Gestão, do Ministério da Ciência e Tecnologia e do Ministério da Fazenda, com o intuito de analisar o quadro de distribuição dos alunos do ensino Superior (BRASIL, 2003), trabalhando com a hipótese de que, para atingir os $40 \%$ de universitários matriculados no setor público determinados pelo Plano Nacional de Educação (2001), seria preciso chegar a 2,4 milhões de vagas no sistema público, dos quais a metade no subsistema federal (BRITO, 2013). O relatório desse grupo de trabalho apontou que o sistema educacional superior do Brasil estava em crise e isso implicava a criação de um sistema emergencial que suprisse a necessidade de expansão da educação superior. A solução pensada, a princípio, seria investir também na educação a distância, pois segundo Brito (2013, p. 3):

\footnotetext{
Partiu do pressuposto de que dadas as dimensões continentais de um país como é o nosso, acrescidas da expressiva demanda existente, as universidades, mesmo com a alocação de recursos adicionais, não teriam condições de atendimento do demandado. O relatório previa, então, um quantitativo de 500 mil vagas a serem ofertadas por meio da EAD, entre 2004 e 2007. Por consequência, a educação a distância surge como um caminho viável e necessário.
}

Havia necessidade de se levar a educação superior para outros locais do país. Diante da pressa em se obter resultados quantitativos rápidos, a EAD passou por bruscas mudanças, e seu processo de amadurecimento foi acelerado por essas demandas, e não houve uma 
organicidade eficiente por parte dos gestores públicos que pretendiam contar com os polos em seus municípios, tampouco discussões ou articulações para que houvesse um entendimento claro do que seria requerido pelos municípios (BRITO, 2013, p. 19):

Grande parte das propostas enviadas ao MEC/SEED, pelos 291 municípios que tiveram polos implantados a partir do Edital $n^{\circ}$. 01/2005 - MEC/SEED foi construída no âmbito das Secretarias Municipais de Educação. Estas, movidas pelo ideal de ter educação superior pública e gratuita em seus próprios municípios, acabaram por construírem consensos junto às administrações municipais que, em sua grande maioria, mostravam-se temerosas em aceitar as condições impostas pelo consórcio, tanto pela falta de recursos orçamentários, quanto pelo fato de que se tratava de um nível de ensino, compreendido pelas prefeituras, como exterior às responsabilidades municipais.

Essa falta de clareza levou muitos gestores a iniciarem o polo de apoio presencial sem a devida estrutura e também sem os subsídios financeiros necessários, pois os recursos demandados para os municípios ainda eram poucos e insuficientes, dada a dimensão que representa subsidiar cursos superiores. Muitos municípios, segundo Brito (2013, p. 5), não estavam preparados para receber projetos desse porte:

A distribuição dos encargos aos municípios fez parte do próprio Edital: as Prefeituras Municipais, individualmente ou regionalmente organizadas, os Governos Estaduais e o Governo do Distrito Federal deveriam apresentar propostas de polo de apoio às atividades presenciais atendendo aos requisitos de infraestrutura física e logística de funcionamento, recursos humanos, viabilidade econômica, entre outros. A ausência de espaços de discussão com a participação efetiva dos municípios, estados e Distrito Federal no processo de construção da proposta, resultou numa total falta de clareza relativa às responsabilidades e aos compromissos que seriam assumidos por cada uma das partes integrantes do Sistema UAB. Decorreu daí uma demora bem maior do que a prevista para que os ajustes nos polos municipais (infraestrutura, logística e recursos humanos) fossem disponibilizados e, finalmente, os cursos de graduação pudessem iniciar suas atividades nos polos municipais parceiros. Cabe aqui uma ressalva: Mesmo que projetada como uma "fábrica" para produzir em larga escala, especialmente, novos professores, o MEC não definiu, nos dois primeiros editais, nem a modalidade de graduação, nem o modelo de proposta pedagógica a ser ofertada por parte das IPES ${ }^{6}$. O objetivo maior do governo federal, à época, parece ter sido muito mais o de "minar" a cultura acadêmica das IPES com a entrada da $\mathrm{EAD}$, do que propriamente focar no campo da formação de professores e/ou na imposição de modelos pedagógicos a serem seguidos pelos projetos de cursos.

O interesse básico era de se obter um quantitativo alto de matrículas, levando também formação superior aos professores que atuavam sem graduação. Não havia um regime de colaboração eficiente e se criou uma má gestão entre os estados e municípios e alguns polos

\footnotetext{
${ }^{6}$ IPES: Instituições Públicas de Ensino Superior.
} 
foram criados desordenadamente, o que acabou levando à perda de um de seus objetivos principais, que é levar educação de qualidade, tornando-se uma "fábrica" de formar alunos (BRITO, 2013).

Essa questão é bem complexa e não poucas vezes deixa de ser discutida conforme apregoa também as pesquisas de Schneider (2013, p. 191):

Nas entrevistas dos professores tutores ficou perceptível uma formação para expandir a educação com baixo custo, com intuito de aumentar estatísticas e formar trabalhadores em educação sem a preocupação com a qualidade dessa formação.

Dada essa realidade cabem reflexões sobre o tipo de educação a distância que se busca e que se tem oferecido aos alunos que tende a não ser eficiente quanto a infraestrutura o que é temeroso e atrapalha desqualificando uma modalidade que deve ter o intuito de ser benéfica e eficaz para o discente em termos de qualidade quanto a formação de professores.

O Decreto $\mathrm{n}^{\circ} 5.800 / 2006$ traz o seguinte texto:

Art. $2^{\underline{0}} \mathrm{O}$ Sistema UAB cumprirá suas finalidades e objetivos socioeducacionais em regime de colaboração da União com entes federativos, mediante a oferta de cursos e programas de educação superior a distância por instituições públicas de ensino superior, em articulação com polos de apoio presencial.

O regime de colaboração entre estados e municípios, segundo Brito (2013), não era contemplado pelos gestores, ficando a cargo dos municípios subsidiar os cursos a distância. Os municípios não sabiam como gerir os polos e se sentiam perdidos quanto à utilização dos recursos injetados pela União, ainda com a dúvida se esse dinheiro serviria para atender à educação infantil em creches e pré-escolas, e, com prioridade, o ensino fundamental, conforme é estipulado pela LDB (1996).

Logo, essa gestão compartilhada, por vezes se apresentava confusa, não atendendo aos anseios dos gestores que muitas vezes viam a oportunidade de contar com o polo da UAB como uma jogada política - ou seja, a UAB serviria para dar visibilidade e angariar votos aos municípios.

Ainda segundo as pesquisas de Brito (2013) os governantes dos municípios não entendiam e tampouco tinham ciência do sentido da UAB e os encargos do polo para a cidade. Brito (2013, p. 7) apresenta o sentimento desses gestores: 
"Nós não sabíamos de nada! Fomos convidados pela universidade para uma reunião que teve por objetivo esclarecer do que se tratava a UAB e sobre o que deveríamos fazer para poder participar e trazer a universidade para o nosso município".

Essa falta de esclarecimento não foi salutar para o nascimento da UAB. Diante desta realidade, há de se discutir os rumos que ela tomou e ainda tomará. Moran (2009, p. 4) também discute essa realidade e comenta as dificuldades de planejamento estratégico da ação em face do crescimento do modelo: "Houve um crescimento desordenado deste modelo, com a instalação de polos em muitas cidades, sem critérios definidos de parceria e sem padrões adequados exigidos de infraestrutura".

A respeito desse crescimento, esta pesquisa realizada no polo da Cidade de Carinhanha - BA, nos anos de 2013-2014, demonstra que, atualmente, o referido polo da UAB naquela localidade ainda não se encontra estruturado de maneira adequada para atender o aluno com qualidade, necessitando de reformas e reestruturação do espaço e dos recursos necessários a um bom atendimento.

Muitos detalhes ainda precisam ser observados para o adequado crescimento da UAB e sua consolidação, de maneira a tornar efetiva a articulação para que a educação a distância se estabeleça como uma modalidade sólida frente às demandas sociais. Atualmente o Brasil ainda tem uma longa caminhada quando se trata da questão da educação a distância, segundo Moran (2009, p. 2):

\footnotetext{
O Brasil se encontra em uma fase de consolidação da educação a distância em todos os setores e níveis de ensino. Depois de uma fase de experimentação, quando houve uma aprendizagem intensa e busca de modelos mais adequados para cada instituição, encontramo-nos em uma fase de amadurecimento, de maior regulação governamental, de maior cuidado com o crescimento, infraestrutura, metodologia de ensino e avaliação.
}

Dada essa realidade, torna-se imprescindível a busca por soluções e as reflexões referentes aos financiamentos, recursos a serem investidos e estratégias necessárias para a adequada articulação entre polos - municípios e União - em um verdadeiro regime de colaboração.

Educar exige compromisso e seriedade. Não adianta ser implementada uma política pública que atenda a um grande número de alunos, sem a devida qualidade, propagando um ensino sem estrutura, apenas com o objetivo de se atingir a quantidade, deixando-se de lado a qualidade, essencial para a formação do aluno.

Sendo assim, é necessário repensar a política pública Universidade Aberta do Brasil, a fim de que soluções possam ser buscadas e se concretizem de maneira que a política atinja 
verdadeiramente seu objetivo e não sirva apenas como propaganda baseada nos números. A função social da educação, para além da democratização do acesso, deve estar vinculada ao acesso à qualidade, o que é conseguida, entre outros fatores, evitando-se que os traços quantitativos a marginalizem e mascarem.

\subsection{A modalidade a distância como inclusão social}

A educação a distância como modalidade de ensino tem se efetivado, propagando um ensino pautado pela democratização do acesso, levando a educação para camadas da população que, por razões marcadamente relacionadas aos aspectos econômicos e sociais, ficaram excluídas do processo educacional.

Diante dessa realidade não só o interior, mas toda comunidade longínqua do país que não conta com infraestrutura de uma instituição de ensino superior em sua localidade, consegue, por meio da educação a distância, ser lembrada e alcançada. Dada essa realidade, discutir a questão da inclusão educacional de pessoas que vivem nessas comunidades e não têm acesso à educação, seja ela básica ou superior, se faz necessário. Para se discutir a exclusão educacional, deve-se falar também na exclusão social. Há verdadeiramente os esquecidos, que ficam à margem devido a suas próprias condições socioeconômicas que os inibe de ter acesso à educação.

As desigualdades e a pobreza oprimem o sujeito, fazendo com que seja esquecido do processo educacional e dificultando a possibilidade da mobilidade social e cultural por meio da escola. Ante ao atual cenário de exclusão e sendo a pobreza um dos motivos da desigualdade educacional, a EAD surge como uma alternativa que aponta para impactos positivos no tocante à acessibilidade à educação superior, especialmente nas instituições federais, sendo estas reconhecidamente, em âmbito nacional e internacional, de grande relevância social e valioso arcabouço de pesquisa e extensão.

Democratizar o ensino é uma tarefa urgente e necessária a fim de termos uma sociedade verdadeiramente inclusiva. No caso do nordeste brasileiro, mais especificamente a Bahia, em 2009, de acordo com a Pesquisa Nacional por Amostra de Domicílios (PNAD), em 2013, 9,15\% da população estadual - isto é, aproximadamente 1,3 milhões de pessoas ou 17,88\% da população baiana - ganhavam menos de meio salário mínimo. 
Esses índices mostram o quanto o Brasil ainda precisa avançar na questão de políticas públicas que alcancem a população com igualdade, diminuindo a extrema pobreza que marginaliza e exclui muitos brasileiros.

A exclusão é uma questão social complexa e não pouco debatida na atualidade. Se o caminho para diminuir a exclusão está na utilização de políticas públicas, como no caso a UAB, estas iniciativas devem ser incentivadas. No entanto, a UAB não é a salvadora da educação, tampouco sozinha consegue atingir o imenso território do Brasil.

Diversos obstáculos podem inibir o indivíduo no que diz respeito ao acesso à educação. Diante desta realidade, a instituição educacional deve se traduzir em um centro de apoio preparado para atender às necessidades do aluno, tanto físicas como acadêmicas, ampliando as oportunidades para o mesmo, agregando e compartilhando conhecimento. Isso não deve ser feito de maneira isolada, mas levando-se em consideração os saberes que o estudante traz e propiciando as oportunidades para a construção de novos saberes críticos e reflexivos.

Entretanto, para que esse ensino tenha qualidade, faz-se necessária uma reforma também social, para que o Estado crie políticas públicas capazes de superar as desigualdades, garantindo o direito à educação e reconhecendo que qualquer tipo de exclusão aumenta a miséria, a falta de perspectivas e inibe um adequado desenvolvimento humano.

Cabe refletirmos acerca dessas e de outras questões tão relevantes e não menos importantes de maneira que esquecidos possam ser lembrados e para obtermos mudanças sociais, por meio de um ensino que ofereça qualidade e busque a inclusão.

3.5 O Sistema Universidade Aberta do Brasil e a questão da Educação a distância: Limites e possibilidades

A Universidade Aberta do Brasil, que atualmente tem como prioridade a democratização do acesso à educação superior, passou por muitas mudanças. Tais mudanças ocorreram justamente para cumprir a determinação de ampliar a população atendida pelo sistema educacional por meio da educação à distância, facilitada pelo desenvolvimento das novas tecnologias.

O Brasil teve dificuldades para conseguir integrar a educação tecnológica ao sistema educacional, enfrentando barreiras sociais, políticas e pouco incentivo governamental. Tais 
dificuldades fizeram com que a proposta de uma Universidade Aberta mediada pelas tecnologias fosse abortada das agendas governamentais, ranqueando o Brasil como sendo o último país com população acima de cem milhões de habitantes a estabelecer uma universidade aberta (SANTOS, 2011).

O país passou por muitas turbulências políticas na segunda metade do século XX, tendo sido perturbado seu processo de implementação da educação tecnológica nas décadas de 1970 e 1980 pelo regime militar, conforme aponta Lacé (2014).

Educadores de destaque no cenário educacional brasileiro já se sobressaíam por seus esforços quanto à democratização do ensino superior público. No entanto, essa iniciativa só tomou forma e ganhou visibilidade no governo Lula da Silva (2002-2010) ${ }^{7}$. Otranto (2004, p.8) explica como essa etapa da formação educacional da população teve seu crescimento acelerado na época em que Lula foi presidente:

A educação a distância é também amplamente defendida pelo primeiro Ministro da Educação do governo Lula da Silva, Cristovam Buarque. No documento intitulado "Universidade numa Encruzilhada", Buarque (2003), prega "a necessidade de uma revolução no conceito de universidade"e essa revolução passa, segundo o autor, pelo ensino a distância que possibilitaria a implantação da "universidade aberta", que seria uma universidade sem muros e sem um campus fisicamente definido. "A universidade do século XXI será aberta a todo planeta.

O ministro da educação de Lula no início do primeiro mandato, Cristovam Buarque, já defendia a ideia de se alcançar o máximo número possível de alunos, democratizando o ensino por meio de tecnologias, ampliando o acesso e resgatando as propostas que foram iniciadas por Darcy Ribeiro ainda na década de 90. Mas com os esforços realizados na época do governo Lula, a expansão tecnológica foi vista como uma excelente ferramenta para a propagação dessa modalidade educativa.

O ministro de Lula era membro do Observatório Internacional das Reformas Universitárias (ORUS), uma ONG francesa dirigida por Edgard Morin, que atuou de forma decisiva, junto ao governo de Lula da Silva, na definição das diretrizes da Reforma Universitária, conforme discute Otranto (2004, p.9):

O ORUS, que direcionou a Reforma Universitária do governo Lula da Silva, patrocinado pelo Banco Mundial, após três meses de fóruns, realizou o Seminário Internacional "Universidade XXI", nos dias 25, 26 e 27 de novembro de 2003, em Brasília. A chamada "discussão democrática" dos pressupostos para a Reforma Universitária se deu através de uma lista de discussão na internet. A discussão, porém, não foi publicada. Somente as mensagens consideradas "mais pertinentes" foram selecionadas pelo 
moderador do ORUS. O principal objetivo: "adequar a educação brasileira às novas tecnologias e demandas do mercado".

Garantir a autonomia universitária, dando primazia ao acesso à educação, esteve na pauta nessa época. No entanto, somente em 2005 foi regulamentada a oferta no Brasil com o decreto $\mathrm{n}^{\circ}$ 5622, de 19 de dezembro, tendo já como ministro de educação Fernando Haddad. A UAB recebeu, então, uma grande propulsão e foi alçada à condição de política pública de destaque na área educacional, sendo, quanto à sua constituição, descrita da seguinte forma:

\begin{abstract}
O sistema UAB é constituído por parcerias entre consórcios públicos nos três níveis governamentais (federal, estadual e municipal), com participação de universidades públicas e demais organizações interessadas. É inegável que o sistema de educação brasileiro vivencia agora um momento histórico tanto para o ensino superior como para o ensino a distância, no qual novas possibilidades de acesso à educação pública estão sendo delineadas. (Santos, 2011, p. 2).
\end{abstract}

Mesmo face ao advento tecnológico crescente, a UAB precisaria de um espaço para se firmar e ser testada quanto a sua funcionalidade. Dada essa realidade, Mota (2009, p. 300) afirma que as primeiras ações de implementação da UAB tinham previstos outros cursos e programas "em diferentes regimes e etapas da educação superior, especialmente aqueles voltados à formação de professores”. Além disso, o estudioso lembra a importância da implantação dos polos de apoio presencial, "especialmente no interior dos estados brasileiros", e conclui:

Tal estrutura acadêmico - administrativa e pedagógica visa à expansão de cursos, tanto formais como informais, a criação de espaços de pesquisa e à estruturação de centro de recursos didáticos, fazendo o uso de todas as mídias disponíveis.

Sabemos que essa UAB tinha como um de seus objetivos a profissionalização do grande número de professores que já atuavam sem a devida formação e necessitavam ter acesso à educação. Para isso, a UAB não poderia perder de vista seu compromisso de educar para a percepção crítica da sociedade, estando, desde o início, vinculada a Universidades Federais de prestígio e destaque no cenário educacional brasileiro.

Investir em uma educação que antes de tudo incentive a emancipação é essencial para o crescimento do país. Utilizar o sistema UAB para a formação de professores se fez necessário nessa realidade, devido à extensão territorial e também às grandes demandas suprimidas do ensino superior que ficavam excluídas da dinâmica educacional. Segundo Mota (2009, p. 300) a criação da UAB visa atender a alguns requisitos para a melhoria do sistema educacional brasileiro, na medida em que: 
A iniciativa integra importantes políticas públicas para a área da educação e tem ênfase em programas voltados para a expansão da educação superior com qualidade e promoção da inclusão social. Em sua essência, o sistema UAB caracteriza-se pela reafirmação do caráter estratégico desse nível educacional, do desenvolvimento científico e da inovação tecnológica para o crescimento sustentado do país, além de estabelecer metas e ações para a promoção da educação inclusiva e cidadã.

O sistema UAB tem entre os seus princípios o de oferecer uma estrutura adequada, utilizando-se das TICs, o que permite um espaço de formação contínua. Além disso, essa formação contínua tem entre seus objetivos o desenvolvimento da autonomia e a construção crítica do conhecimento: o estudante deve saber gerir de maneira consciente sua autonomia, conciliando seus estudos às necessidades do curso ofertado e também da estrutura que será oferecida. Dada essa realidade, a UAB, em parceria com os municípios das cidades que abarcaram o projeto, deverão oferecer, segundo Mota (2009, p. 31):

Um local estruturado que atenda adequadamente estudantes de curso a distância. Seria o espaço onde o estudante teria acesso local à biblioteca, laboratórios acadêmicos (de química, física e biologia, entre outros), laboratório de informática, por exemplo, para acessar os módulos do curso disponíveis na internet.

O polo de apoio presencial representaria o local onde o aluno se sentiria acolhido, sendo um centro de referência pronto, equipado e preparado para atender o estudante. Mota (2009, p. 301) explica como deve ser a estrutura desse polo:

Uma estrutura para a execução descentralizada de algumas das funções didático-administrativas de curso, consórcio, rede ou sistema de EAD, geralmente organizada com o concurso de diversas instituições, bem como com o apoio dos governos municipais e estaduais.

O polo da UAB necessita oferecer uma estrutura apropriada para atender o aluno com qualidade. A UAB atualmente conta com um bom quantitativo de polos: cerca de 680 polos ativos de acordo com o site da Capes, atendendo 800 mil alunos por ano. Dada essa realidade, há de se ter uma cultura tecnológica para se propagar o sistema UAB, conforme defende Santos (2011, p. 3):

A capacidade de promover a interiorização do ensino público é uma das facetas mais marcantes da UAB. Dois pontos devem ser observados no momento da avaliação prévia para credenciamento dos cursos, quais sejam: a existência na região de uma cultura tecnológica propícia a receber essa modalidade de ensino e o nível de interesse do poder público local ser um agente facilitador do processo. O uso das TIC é importante e necessário para os alunos, pois é por meio dessas tecnologias que eles têm acesso a: atividades, conteúdos, aulas, leituras complementares, chat, web conferência e outros. 
É preciso ter um nível de aceitação favorável para a difusão e propagação do sistema UAB de maneira apropriada para que ela consiga atingir o estudante com a devida qualidade.

É importante também questionarmos a questão da precarização do ensino oferecido e se ele tem tido a qualidade devida favorecendo as camadas que necessitam aprender com qualidade. De acordo com Santos (2011, p. 4): “A UAB pode vir a se tornar um exemplo emblemático dessa condição de massificação e precarização da formação do sujeito na Educação Superior, se não se atentar para a qualidade na modalidade em EAD.”

Sabemos que a questão da qualidade implica antes de tudo uma estrutura adequada aos sujeitos envolvidos. Caso contrário, o ensino não cumpre com sua finalidade e se compromete a sua eficácia. Priorizar a qualidade ao invés da quantidade significa não focar apenas no alcance desse sistema e sim na eficácia do ensino oferecido, sendo mais importante a solidez da aprendizagem. Nesse sentido, é preciso evitar que um grande contingente de estudantes alcançados pelo sistema educacional, possível graças à educação a distância, não seja atingido pela mera massificação e pela corrupção do sistema devido à falta de estrutura.

A educação a distância é uma possibilidade educativa de ressignificação paradigmática no contexto da formação de professores, pois auxilia no processo de troca, mediando a construção coletiva do conhecimento entre todos em um processo colaborativo. Logo, esse processo deve se atentar para a qualidade, pois se trata de uma construção que requer atenção e cuidados quanto ao ensino oferecido.

Enxergar essa política pública como um investimento deve estar na pauta do governo, que não só incentiva, mas também contribui para o crescimento do país. Impedir a precarização desse ensino, firmando a UAB como política efetiva, é importante para que essa modalidade de ensino se aperfeiçoe e se propague. Segundo Zuin (2006, p. 942), “apenas 10\% dos jovens entre 18 a 24 anos têm acesso ao ensino superior”. É um percentual baixíssimo para um país com as dimensões e as pretensões do Brasil no cenário internacional. Nesse sentido, o crescimento do atendimento da população jovem brasileira por meio da EAD é altamente recomendável, pois pode auxiliar na aceleração do processo de desenvolvimento educacional do país.

Os cursos do consórcio UAB contribuem com a população local, como no caso de pequenos municípios que não contam com um grupo de professores formados e são favorecidos por esse sistema de ensino. Além da formação de professores, são oferecidos outros cursos, aumentando as possibilidades de profissionalização e acesso ao conhecimento 
por parte da população, seja nos níveis de graduação ou de especialização. O impacto de tais iniciativas nas cidades contempladas com o programa é bastante significativo, pois há um aumento do nível de escolaridade, ampliando assim as possibilidades da inserção dos estudantes no mercado de trabalho e de maneira mais diversificada.

Mesmo com essas vantagens, a UAB pode ter seus sucessos travados por diversos motivos. Entre eles são mais comuns: a estrutura física do polo de atendimento ao aluno ser inapropriada; ou até mesmo, o pouco interesse da população em realizar cursos superiores, devido à falta de perspectiva profissional em curto prazo. Por isso, observa-se com preocupação o problema da evasão na UAB. Santos (2011, p. 10) alerta:

Essa democratização reflete na expansão prometida pela UAB, e no número cada vez maior de vagas oferecidas. Contudo, a exemplo dos demais cursos superiores, os índices de evasão aparecem como entrave para esse "sucesso". A falta de dados concretos dificulta o diagnóstico real da situação, e com isso ações para reverter o problema não são tomadas.

Essas ações que não são tomadas acabam por contribuir para os altos índices de abandono que são reais e crescem com enormes proporções. São diversos os problemas que podem afligir o aluno que estuda à distância, desde a origem social, passando pelo pouco tempo para a execução das tarefas já que precisam trabalhar, até chegar à própria formação deficitária nos níveis de ensino anteriores e que terminam por dificultar a aprendizagem. Dessa maneira, tais questões precisam ser discutidas e estudadas, de modo a levantar os pontos frágeis da EAD, com o intuito de auxiliar os estudantes por meio de ações que lhes favoreçam quanto a sua permanência nos cursos. Garantir o acesso e garantir a permanência, por meio de bolsas e auxílios, é primordial.

A educação superior pública necessita ser considerada como um direito e não ser vista apenas como um gasto. É, sim, um investimento que visa à emancipação social dos indivíduos através do conhecimento e do desenvolvimento de uma visão mais crítica do mundo. Educação não é um privilégio, tampouco um serviço, mas sim um direito que o cidadão merece usufruir.

A UAB, portanto, deve oferecer possibilidades e ser viva e atuante na sociedade do conhecimento na qual está inserida. Nesse sentido, a UAB pode desempenhar um papel fundamental no sistema educacional, possibilitando o acesso das camadas sociais mais pobres ao sistema de ensino, contribuindo para a redução da desigualdade e para a emancipação cultural, política e econômica da população atendida. 
3.6 O percurso acadêmico do sujeito que estuda à distância: algumas reflexões sobre suas trajetórias

A educação superior é vista como etapa importante na formação da pessoa, pois tem a característica de profissionalizar o indivíduo para o mercado de trabalho. Galgar até o nível superior pressupõe uma caminhada acadêmica permeada de dificuldades, essas que fazem parte da vida do estudante.

Um sujeito que vivencia desigualdades sociais e econômicas em sua trajetória terá menos chances de chegar até um nível superior, pois os fatores socioeconômicos, no que diz respeito não somente ao acesso à educaçao, em alguns casos, são determinantes para a permanência ou não do aluno no curso escolhido.

Nesse sentido, os estudos de Lahire (1997) são interessantes, pois trazem a questão da trajetória de alunos que mesmo em condições pouco prováveis de sucesso escolar, como no caso de crianças que vivenciam uma situação social desfavorável, conseguiram chegar ao nível superior. Tais estudos deverão ser utilizados em pesquisas futuras, pois ressaltam as condições sociais, as quais não são determinantes e sim subjetivas. Os fatores que podem determinar o sucesso ou o fracasso do estudante dependem, segundo o autor, do apoio ou incentivo que o mesmo terá na família, aliado à herança cultural. Nesse sentido, o processo de aprendizagem do estudante mantém estreita relação entre o indivíduo e sua intersubjetividade, ou seja, leva em conta os aspectos psicológicos que o envolvem.

Portes (2000) discute a respeito do trabalho desenvolvido pela família em prol do ingresso e permanência dos filhos no sistema de ensino, procurando influenciar sua trajetória escolar, com o intuito de incentivá-los a alcançar níveis mais elevados em sua escolaridade. Segundo Portes (2000), trata-se de um trabalho complexo e penoso realizado em alguns casos por famílias que não possuem capital escolar e herança cultural significativa.

A influência positiva dos professores é um fator que Portes (2000) também traz em sua pesquisa, concluindo que, quando existe incentivo, apoio e acompanhamento apropriados, há uma elevação na autoestima do aluno, colaborando para o seu sucesso escolar. Para Portes (2000), a escola, no que diz respeito à sua atuação, da educação básica até o ensino médio, pode ser, sim, quando bem direcionada, um fator determinante no acesso ao nível superior por parte da camada mais pobre da população.

Sabemos que a trajetória de um adulto, ainda que cada um tenha suas particularidades, é marcada por diversas questões sociais. Há um entendimento que perpassa a escola de que 
uma trajetória de sucesso se deve ao esforço único e particular das pessoas, e que por ser o ensino ser público, o acesso seria igual para todos.

No entanto, sabemos que na prática isto não funciona e a escola serve muitas vezes para excluir e segregar o estudante em seu processo educacional, seja por suas bases estruturantes que preconizam um saber acadêmico muito fora do contexto do aluno, seja por questões psicológicas relacionadas a como o aluno vai se portar dentro do ambiente educativo, ou no que diz respeito às condições sociais e materiais que asseguram a permanência no espaço escolar por um tempo maior.

Há um prolongamento do ensino médio, o que implica dizer que os estudantes estão demorando mais tempo em um nível de ensino que deveria permanecer na média de três anos. A permanência do aluno por mais tempo no mesmo nível de ensino ocasiona uma quebra na sequência acadêmica do estudante, sendo mais um dos aspectos que explicam o número menor de estudantes no nível superior. Há uma permanência mais longa no ensino fundamental e médio e menor na educação superior, conforme demonstra Ennafaa (2012, p. 165):

\footnotetext{
O Brasil se destaca por suas matrículas (taxas líquidas específicas por idade 15 a 20 anos) particularmente baixas no ensino superior (18 a 20 anos). A maioria dos jovens nessas faixas etárias ainda está matriculada no ensino médio, ou até mesmo no ensino fundamental (PNAD, 2011). Aos 19 anos, $31,1 \%$ estão matriculados ainda no ensino médio, só $13,2 \%$ estão no ensino superior.
}

O vestibular para Ennafaa (2013, p. 177) é visto como um "concurso", e nem todos teriam as mesmas condições de enfrentá-lo. Fatores sociais são decisivos. Na mesma direção, Silva (2011, p. 13) afirma: “O vestibular contribui para a reprodução daquelas profundas desigualdades sociais que constituem um traço distintivo da sociedade brasileira".

Nem todos têm a mesma chance de conseguir êxito nesse concurso, chegando a um nível superior. A lógica ainda é desigual e desalinhada frente às demandas que apresentam. Ennafaa (2013, p. 187) avança quanto a esse aspecto: “Os matriculados continuam sendo poucos diante dos números de jovens da faixa etária 18 e 24 anos, em sua maioria "excluída de um sistema de formação acessível e gratuito".

A trajetória do educando passa pelas etapas de acesso, permanência e êxito. Por diversos fatores sociais, culturais e econômicos, constata-se uma ruptura na vida escolar que compromete a permanência do sujeito no sistema educacional e, consequentemente, o acesso à educação superior. 


\section{O PERCURSO METODOLÓGICO DA PESQUISA}

\subsection{Metodologia da pesquisa}

A pesquisa qualitativa, segundo Gonsalves (2007), trabalha aspirações, crenças, valores, sentimentos e atitudes, o que corresponde a um espaço mais profundo das relações, dos processos sociais e dos fenômenos que não podem se reduzir à operacionalização de variáveis. Gil (1999, p. 42) conceitua esse tipo de pesquisa definindo-a com o seguinte objetivo:

\footnotetext{
O objetivo fundamental da pesquisa social é descobrir respostas para problemas mediante o emprego de procedimentos científicos. A partir dessa conceituação, pode-se, portanto, definir pesquisa social como o processo que, utilizando metodologia científica, permite a obtenção de novos conhecimentos no campo da realidade social.
}

A pesquisa realizada neste trabalho é de natureza exploratória e descritiva. De acordo com Gil (2008), as pesquisas descritivas possuem como objetivo a descrição das características de uma população, de um fenômeno ou de uma experiência. Logo, serão descritas com a riqueza própria, preservando-se seus detalhes e captando o que é relevante dentro dos objetivos da pesquisa. Ela também assumirá características exploratórias, no sentido de se esmiuçar a fundo os eixos categóricos que serão trabalhados, buscando a familiaridade e a aproximação com os objetivos a serem explorados.

A metodologia é constituída por três fases. A primeira diz respeito à aproximação da pesquisadora com os sujeitos da pesquisa. A segunda trata da coleta dos dados por meio de questionário, com perguntas abertas e fechadas, com o intuito de conhecer a trajetória dos egressos, bem como esmiuçar alguns objetivos respondidos na pesquisa. O questionário, segundo Gil (1999, p.128) pode ser definido como "a técnica de investigação composta por um número mais ou menos elevado de questões apresentadas por escrito às pessoas, tendo por objetivo o conhecimento de opiniões, crenças, sentimentos, interesses, expectativas, situações vivenciadas, etc.” Algumas vantagens quanto à utilização do questionário são apontadas por Gil (1999, p. 128 e 129):

a) possibilita atingir grande número de pessoas, mesmo que estejam dispersas numa área geográfica muito extensa, já que o questionário pode ser enviado pelo correio; b) implica menores gastos com pessoal, posto que o questionário não exige o treinamento dos pesquisadores; c) garante o anonimato das respostas; d) permite que as pessoas o respondam no momento em que julgarem mais conveniente; e) não expõe os pesquisadores à influência das opiniões e do aspecto pessoal do entrevistado. 
Dessa forma, o questionário serviu como principal meio de coletar dados para este trabalho; dados esses que foram tratados e analisados de acordo com sua relevância e levando-se em consideração a metodologia utilizada, tanto no tratamento como na coleta. $\mathrm{Na}$ ocasião da primeira visita a Carinhanha, ocorrida no mês de abril de 2013, alguns questionários foram aplicados aos formandos da UAB 2 e serviram de objeto de estudo desta pesquisa.

A terceira fase trata da entrevista, que teve o intuito de coletar e analisar as narrativas de cada sujeito e, por meio de sua fala, dar sentido e responder questionamentos essenciais relacionados a sua trajetória acadêmica, ressaltando as dificuldades enfrentadas na realidade de Carinhanha-BA.

$\mathrm{Na}$ ocasião da primeira ida a campo, em abril de 2013, foram aplicados 25 questionários e realizadas 2 entrevistas narrativas. Na segunda ida a campo, em março de 2014, foram realizadas mais 5 entrevistas narrativas totalizando 7. A escolha das 7 entrevistas deve-se aos critérios estabelecidos pela pesquisa cuja opção foi selecionar alunos graduandos do curso de Pedagogia da FE-UnB / UAB pertencentes à turma UAB 2.

Nesse momento da pesquisa, foi utilizado o instrumento da entrevista narrativa, bastante similar à entrevista semi-estruturada (FLICK, 2009). A entrevista narrativa se inicia com uma pergunta gerativa que dará impulso à narrativa do entrevistado. Portanto, essa pergunta desencadeará diversas falas que darão margem a outras perguntas, seguindo os objetivos propostos pela pesquisa e, desse modo, captando não apenas o que levou o sujeito àquela determinada ação, mas também os fatores que o influenciaram e que estão no seu discurso, revelados por meio de vivências, saberes e experiências. Sobre a entrevista, Triviños (1987, p. 85), porém, adverte: “as indagações propostas ao sujeito, além de serem claras, precisas e expressas numa linguagem natural, adequada ao ambiente no qual se realize a pesquisa, devem apontar os assuntos medulares do problema".

Flick (2009) diz que a narrativa começa com a história de vida do entrevistado e devido a sua riqueza de informações, aos poucos, traz mais detalhes que são relevantes para a pesquisa. Ele propõe também que o entrevistador deve ter a escuta ativa, evitando muitas interferências.

A entrevista narrativa neste trabalho parte das aspirações do entrevistado e também da história de vida do sujeito e tem o intuito de analisar como se deu o processo de escolarização em Carinhanha, no que diz respeito à educação a distância oferecida naquela localidade. 
Aescolha dos sujeitos da pesquisa aconteceu de acordo com a disponibilidade e do interesse dos formandos em participar. Sendo selecionados de acordo com os seguintes critérios: a) Serem alunos do curso de Pedagogia a distânciada UnB - UAB, em Carinhanha, pertencentes à turma UAB 2. b) Aceitação em participar da entrevista narrativa seguindo a dinâmica apresentada.

Essas entrevistas foram interpretadas a partir da análise de discurso crítica. Nesta perspectiva, conforme Resende e Ramalho (2013), o discurso é visto como um momento de prática social ao lado de outros momentos igualmente importantes - e que, portanto, também devem ser privilegiados na análise, pois o discurso é tanto um elemento da prática social que constitui outros elementos sociais, como também é influenciado por eles, em uma relação dialética de articulação e internalização.

A análise de discurso crítica possibilita a chegada ao âmago da questão, partindo de um pressuposto dialético que não se limita a simples descrições, mas sim a um estudo comprometido com a reflexão sobre a sociedade e sobre a própria análise. Resende e Ramalho (2013, p. 37) explicitam essa realidade: "Por fim, toda pesquisa em análise de discurso crítica deve conter uma reflexão sobre a análise, isto é, toda pesquisa deve ser reflexiva”.

Reflexão e interação com os discursos do sujeito de maneira que a linguagem traduza suas percepções e ações são essenciais para se terem dados tratados de maneira dialógica. Logo, o trabalho com os materiais colhidos, segundo Nogueira (2011, pág. 33), e tratados por essa técnica deverá levar em consideração o seguinte:

\footnotetext{
É importante voltar a fazer referência, que não basta ter material (muita informação proveniente de documentos, transcrições de muitas entrevistas) para, de um momento para o outro, se iniciar uma pesquisa de Análise do Discurso, pensando-se que se vão encontrar revelações importantíssimas. Aquilo que se considera como sendo material só se torna verdadeiramente "dados" depois das decisões teóricas dos pesquisadores acerca das diferentes abordagens discursivas, dos posicionamentos epistemológicos subjacentes, assim como acerca do tópico específico de pesquisa.
}

É preciso seguir uma sistemática que atenda aos objetivos da pesquisa e traduza as intenções do que necessita ser verdadeiramente pesquisado. Deve-se seguir os passos da análise, conforme aponta Nogueira (2001), não de maneira rígida, mas sim de uma maneira crítica, estabelecendo uma reflexão acerca do que os dados apresentam.

Nogueira (2001, pág. 34) expõe, assim, os passos da pesquisa, segundo tal método: 


\section{Textos}

1- tratar objetos de estudo como sendo textos (colocados em palavras);

2- explorar conotações, associação livre;

Objetos

3- procurar objetos nos textos;

4-tratar a fala acerca desses objetos como objeto de estudo;

Sujeitos

5- especificar sujeitos (pessoas, assuntos, temas, etc.), como tipos de objetos no texto;

6- especular acerca de como eles podem "falar";

Sistema

7- traçar uma imagem do mundo, redes de relações;

8- indicar as estratégias defensivas desses sistemas contra possíveis ataques;

Ligações

9- identificar contrastes entre formas de "falar";

10- identificar pontos de sobreposição, fala dos mesmos objetos;

Reflexão

11- relacionar maneiras de falar para audiências diferentes;

12- escolher rótulos ou designações das formas de falar, os discursos;

História

13- analisar com atenção como esses discursos emergem;

14- questionar como os discursos contam a sua história acerca da sua origem; Instituições

15- identificar instituições reforçadas pelos discursos;

16- identificar instituições que são atacadas pelos discursos;

Poder

17- analisar que categorias de pessoas ganham e perdem;

18- questionar quem os promoverá e quem se lhes oporá;

Ideologia

19- analisar como eles se ligam com outros discursos opressivos;

20- descrever como eles justificam o presente.

As vinte fases são apenas algumas diretrizes a serem levadas em consideração, não de maneira impositiva que engesse os dados coletados, mas de modo a tratá-los com leveza e flexibilidade por parte do/a pesquisador/a. Fundamentalmente, a análise de discurso crítica contemplou as categorias relacionadas às trajetórias, condições de vida no lugar e perspectivas de longevidade escolar. Outras categorias que se ligam a estas centrais surgiram durante o processo de coleta do material - como as questões de gênero - e também tiveram espaço na análise, respeitando-se os critérios de relevância da pesquisa de acordo com os eixos categóricos estabelecidos. 
4.2 Os sujeitos da pesquisa

Os sujeitos da pesquisa foram os egressos do curso de Pedagogia. Esses deram sentido aos objetivos da pesquisa, frente ao que foi construído e analisado tanto no questionário como na entrevista.

O aluno de EAD é, na grande maioria das vezes, adulto, segundo apontam os estudos de Lopes, Lisniowski e Jesus (2011, pag. 2):

Dados do perfil dos alunos do curso, tomando as orientações dos editais como referência, mostram que estes alunos têm uma média de idade de 33 anos; residem, em sua maioria (60\%), na cidade sede do polo, enquanto que $40 \%$ moram em outras cidades, com situações bastante contrastantes entre os polos.

Os sujeitos que particparam da pesquisa são discentes da turma UAB 2, que era formada por 32 mulheres e 3 homens. A figura da mulher é ainda forte em cursos de licenciatura como no caso da pedagogia.

Os egressos do ano de 2014 foram os sujeitos que fizeram parte da pesquisa, num total de 25 , um número significativo, levando em consideração a realidade de evasão que ocorre em diversos polos, conforme aponta Lopes, Lisniowski e Jesus (2011, pag. 18):

A evasão tem-se constituído como um dos grandes desafios da modalidade a distância, exigindo da gestão educacional a elaboração de estratégias e ações que minimizem as dificuldades dos alunos para permanecer no Curso. No âmbito da educação superior, tanto nos cursos presenciais quanto nos cursos a distância, a evasão tem sido colocada como objeto de pesquisas e nas pautas da discussão daqueles envolvidos na oferta de cursos, com destaque na modalidade a distância.

Esses egressos representam, portanto, um número alto, pois conseguiram permanecer no curso rompendo com as estatísticas de evasão, ainda muito presentes nos cursos superiores na modalidade a distância.

\subsection{A pesquisadora frente ao objeto de pesquisa}

A pesquisadora possui um arcabouço de ideias e ideários que influenciam suas práticas dentro e fora do labor acadêmico. Mills (1975) diz que o pesquisador deve aprender a usar a experiência de sua vida em seu trabalho continuamente. Segundo Mills (1975), só se controla a experiência por meio da organização de um arquivo, ou seja, um diário. Algumas ideias podem surgir em conversas casuais, por isso devemos anotá-las para que possamos revisá-las, 
adotá-las ou descartá-las, seguindo uma sequencia lógica e coerente frente às indagações da pesquisa.

Mills (1975) destaca ainda que não devemos abrir mão de nossa autonomia na pesquisa, não devemos permitir que questões públicas e outras preocupações determinem os problemas que estudamos. O problema deve surgir de nossa prática, de nossa vivência e no âmago de nossos questionamentos.

Respeitar e não impor é papel do pesquisador, criando condições e um clima favorável para que esse entrevistado exponha suas vivências e subjetividades, essas que muitas vezes se escondem - por uma má imposição ou condução do pesquisador. Diante dessa realidade, o pesquisador não é neutro nesse processo. É sim um sujeito que tem suas vivências, ideais e subjetividades próprias e particulares à sua realidade.

\section{NAS TRILHAS DA EDUCAÇÃO SUPERIOR A DISTÂNCIA: A VOZ DOS EGRESSOS DA UnB - UAB NO MUNICÍPIO DE CARINHANHA - BA}

\subsection{O polo de Carinhanha- $\mathrm{BA}^{8}$}

A Universidade de Brasília atualmente tem um polo, conhecido pelo nome de Dona Carmem, localizado em Carinhanha, um pequeno município de 28.380 habitantes $^{9}$ - no Estado da Bahia, nordeste brasileiro, onde oferece cursos de graduação a distância de Pedagogia e Letras. O curso de Pedagogia que foi oferecido pela UnB, turma UAB 2 - contava com aproximadamente 35 alunos frequentes.

O polo funciona em uma escola grande no centro de Carinhanha. Conta com uma secretaria, onde trabalha a tutora presencial, e outra sala para apoio e atendimento aos alunos. Não possui uma biblioteca, há um pequeno acervo - doação, em sua maioria - de livros

\footnotetext{
${ }^{8}$ A primeira fase da pesquisa foi realizada em abril de 2013 na ocasião do encontro presencial que ocorreu entre alunos, tutores e professores para a primeira orientação de monografia dos estudantes. Logos os dados relatados foram coletados no local da pesquisa.

${ }^{9}$ Disponível em: BRASIL, INSTITUTO BRASILEIRO DE GEOGRAFIA E ESTATÍSTICA. Dados censitários dos

Brasileiros. <http://www.cidades.ibge.gov.br/painel/painel.php?codmun=290710\&search=bahia\%7Ccarinhan ha\%7Cinfograficos:-dados-gerais-do-municipio\&lang>. Acesso em: mar. de 2013.
} 
didáticos do ensino fundamental. Há alguns computadores, mas a internet do local, segundo a tutora presencial, é lenta, e isso algumas vezes atrapalha a aprendizagem dos alunos.

Os cursos que foram aprovados em 2007 e são oferecidos pela Universidade de Brasília e também por IES públicas do estado da Bahia apontam para outra questão. A Universidade de Brasília, portanto, não é a única parceira do programa UAB naquela localidade, pois a UNEB (Universidade Estadual da Bahia) e a Universidade Estadual do Sudoeste da Bahia (UESB) também oferecem cursos a distância, conforme relacionado na tabela a seguir.

TABELA 1 - Cursos ofertados no Polo de Carinhanha

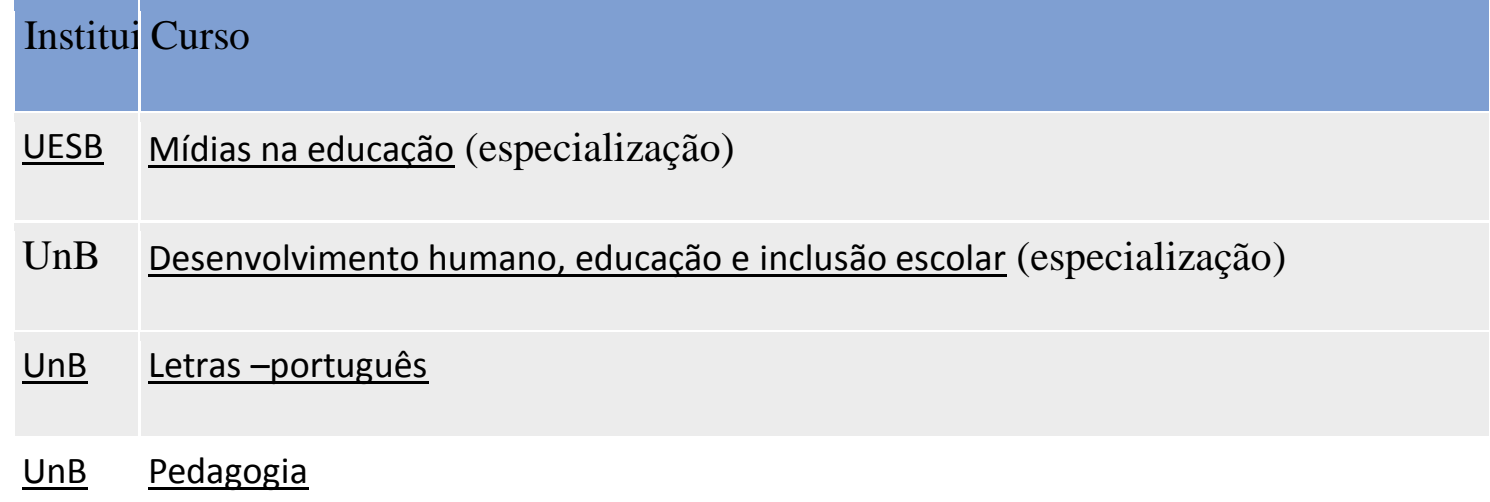

$\underline{\text { UNEB }} \underline{\text { Administração pública }}$

$\underline{\text { UNEB }}$ Biologia

UNEB Gestão em saúde (especialização)

$\underline{\text { UNEB }}$ Matemática

$\underline{\text { UNEB }}$ Pedagogia

Disponível em: Portal da Universidade Aberta do Brasil:
〈http://sisuab.capes.gov.br/sisuab/PesquisasUAB/Curso show.action?id=386>. Acesso em: janeiro de 2014.

Os cursos atendem estudantes de Carinhanha e também de cidades próximas. A UnB e as outras duas instituições de educação superiores públicas, a UNEB e a UESB, aderiram ao projeto UAB democratizando o acesso à educação pública em nível de graduação e especialização, beneficiando aquela localidade. 
5.2 Resultados e discussão dos dados coletados na pesquisa

A pesquisa foi realizada utlizando-se o questionário já mencionado no capítulo 3 e também as entrevistas narrativas. O questinário serviu de base para se entender a realidade socioeconômica desses sujeitos. As entrevistas narrativas foram aplicadas com o intuito de se extrair os dados sociais, econômicos e das trajetórias dos entrevistados a partir de suas perspectivas.

5.3 Análise do Perfil socioeconômico do estudante de Carinhanha - BA do curso de Pedagogia - Fe-UnB / UAB

O questionário foi realizado com estudantes pertecentes à UnB - UAB do curso de Pedagogia da turma UAB 2. São em sua maioria mulheres, na faixa etária de 26 a 33 anos.

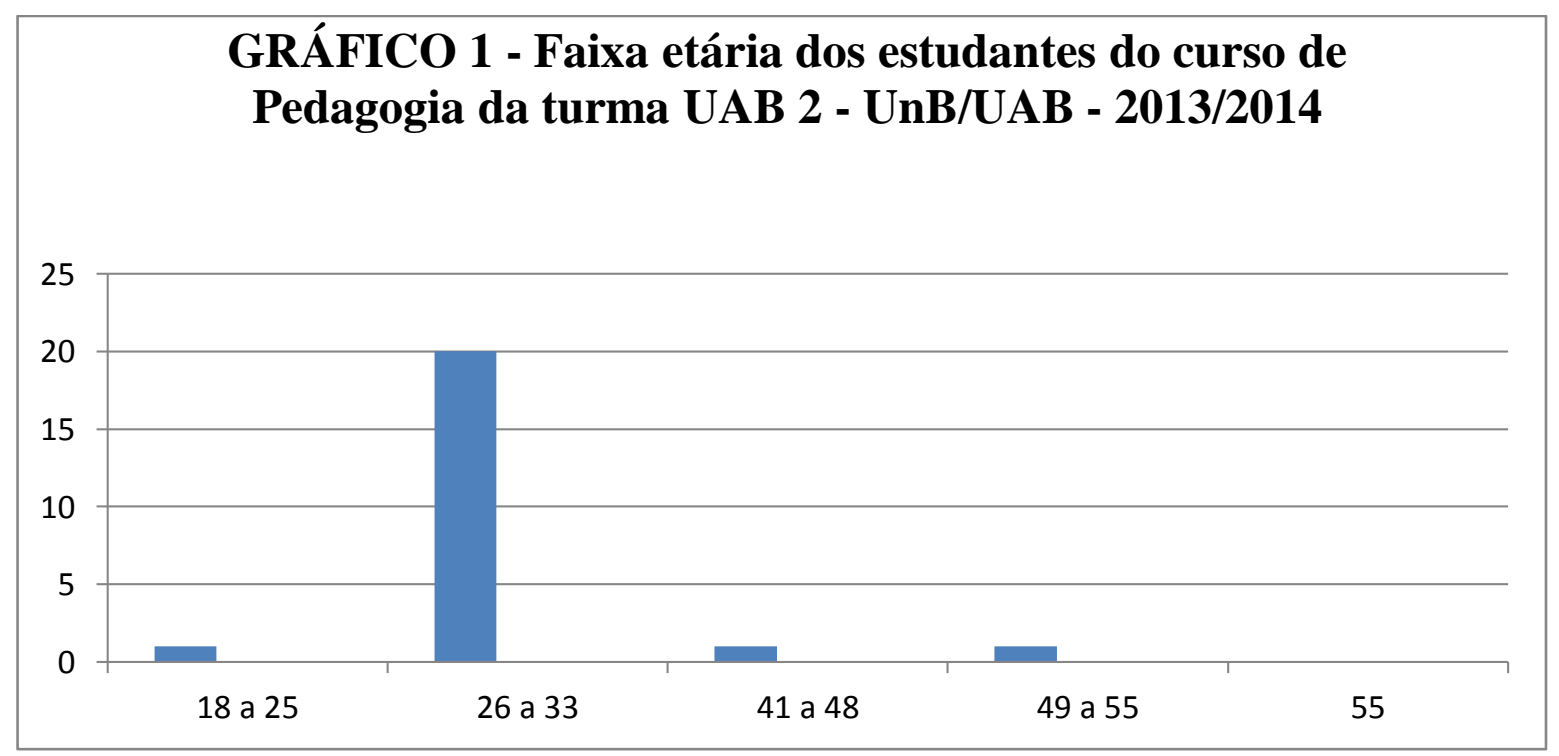

Os dados quanto à faixa etária apontam características interessantes no que diz respeito ao público alvo da EAD. Em sua maioria, totalizando 20 adultos que têm mais de 26 anos, convergindo com os dados da pequisa de Lopes, Lisniowski e Jesus (2008). Geralmente a EAD é voltada para adultos, também conforme aponta Rodrigues (1998, p.10): 
E, no entanto, cada vez mais adultos atualizam conhecimentos e aprendem a distância, sobretudo por falta de tempo para dar conta da quantidade crescente de informações em circulação no mundo atual. Por ser uma modalidade que requer autonomia por parte dos discentes, são requeridos do aluno disciplina e gestão apropriada do tempo para que os alunos estabeleçam adequadamente suas aprendizagens.

A autonomia, característica marcante da EAD, exige responsablidade por parte do aluno em relação à aprendizagem, bem como maturidade para que ele consiga gerir sua aprendizagem de maneira adequada. Logo, essa modalidade, dadas as suas características, requer posturas e ações condizentes e apropriadas à flexiblidade que esse ensino apresenta.

Com relação à renda dos estudantes, o gráfico a seguir apresenta em sua maioria a renda de 2 salários mínimos como sendo a mais comum entre os estudantes.

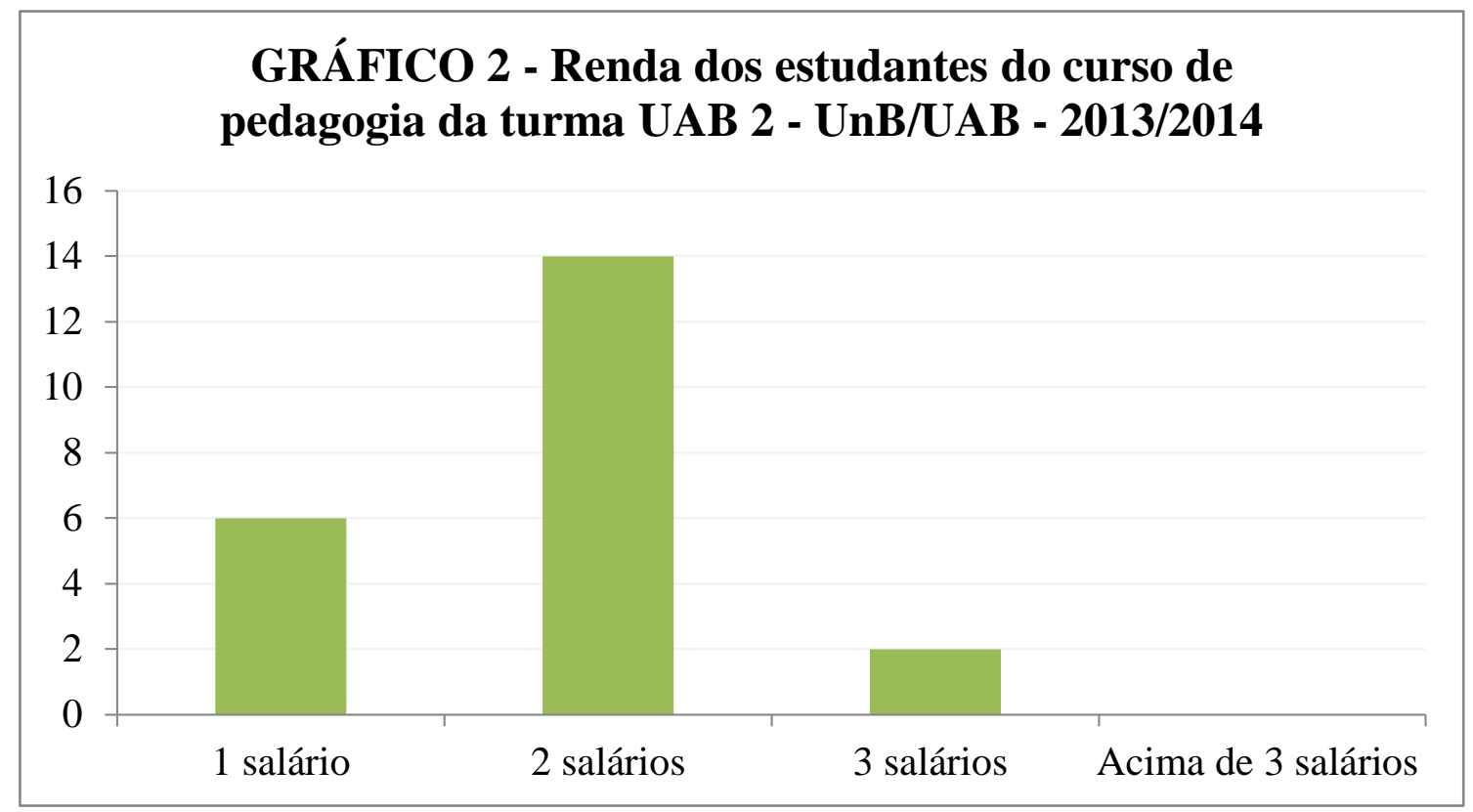

Todos os estudantes exerciam algum tipo de atividade profissional e obtinham seu sustento. São adultos com responsabilidades que dividiam seu tempo entre os estudos, o trabalho e grande parte com os filhos. Dos 25 sujeitos que responderam ao questionário, 22 são casados, sendo esses sujeitos do sexo feminino. Esses formandos têm em média de 2 a 4 filhos.

Os formandos ganhavam em média 2 salários mínimos e atuavam tanto na rede pública como privada de Carinhanha - BA. Em geral, a média salarial desses profissionais era 
baixa, um pouco acima do piso nacional da categoria - de acordo com a lei $11.738^{10}$, de 2008 , nunca menor que $\mathrm{R} \$ 950,00$ (novecentos e cinquenta reais), no caso de professor que atuava só com nível médio.

Esses profissionais ganhavam em média $\mathrm{R} \$ 1.356,00$ reais por mês, uma quantia razoável em relação ao piso instituído por lei, no entanto, esses sujeitos atuam tanto na rede pública como na rede privada de Carinhanha, tendo uma carga de trabalho pesada e cansativa, o que é ruim para o trabalho docente.

5.4 A análise de discurso crítica a partir do perfil dos estudantes

Foram realizadas na pesquisa sete entrevistas narrativas com a turma UAB 2 da Universidade de Brasília em Carinhanha. A análise dessas narrativas, conforme já ressaltado, teve o intuito de captar a fala do sujeito de maneira crítica, retratando suas subjetividades. Foram utlizados dois roteiros na pesquisa, o primeiro realizado em abril de 2013 e o segundo em março de 2014. A partir das entrevistas foram analisadas as falas, de acordo com o que preconizam Resende e Ramalho (2013, p. 42):

A Teoria Social do Discurso é uma abordagem de Análise de Discurso Crítica (ADC), desenvolvida por Norman Fairclough, que se baseia em uma percepção de linguagem como parte irredutível da vida social dialeticamente interconectada a outros elementos sociais. Trata-se de uma proposta que, com escopo de aplicação, constitui modelo teórico-metodológico aberto ao tratamento de diversas práticas na vida social, capaz de mapear relações entre os recursos linguísticos utlizados por atores sociais e grupos de atores sociais e aspectos da rede de práticas em que a interação discursiva se insere.

O discurso é visto como prática social e se constitui da fala do sujeito. Dar espaço à reflexividade é o pressuposto fundamental da análise do discurso crítica que dá primazia ao elemento do discurso, ou seja, a fala do sujeito conforme ressalta Resende e Ramalho (2013, p. 45):

Reflexividade é um outro conceito caro para a ADC (análise de discurso crítica), pois reflexividade sugere que toda prática tem um elemento discursivo, não apenas porque envolve, em grau variado, o uso da linguagem mas também porque construções discursivas sobre práticas são também parte dessas práticas.

\footnotetext{
${ }^{10}$ Disponível no site: Brasil.<http://www.planalto.gov.br/ccivil_03/_ato20072010/2008/lei/111738.htm>. Acesso em: mar. de 2013.
} 
Reflexividade, conforme é proposto pela análise de discurso crítica, interação com os sujeitos e relevância à fala desse sujeito são os pressupostos dessa metodologia de pesquisa. As vozes terão seu espaço obedecendo à intertextualidade presente na fala dos estudantes, seguindo uma distribuição linguística que será representada de acordo com o que ensina Resende e Ramalho (2013, p. 101): “Tal distribuição está organizada de acordo com algumas possiblidades linguísticas de realização da intertextualidade, quais sejam, o discurso direto, o discurso indireto e a pressuposição". Desse modo, a seleção das vozes segue uma perpectiva crítica na qual a pesquisadora está alicerçada. Resende e Ramalho (2013, p. 101) ressaltam: “A seleção das vozes nessa recontextualização, bem como as maneiras como elas são representadas dizem muito sobre o seu posicionamento político desse evento discursivo na rede de práticas sociais".

Analisar de maneira crítica, dando primazia, portanto, à voz do sujeito, ao que ele ressaltou em sua fala, será o posicionamento utilizado ao longo da discussão dos dados da pesquisa.

5.5 Discussão do perfil acadêmico dos estudantes de Carinhanha - BA

Partindo do discurso dos sujeitos, notamos que os egressos, quando indagados sobre a leitura e escrita exigidas pela academia, apresentaram algumas respostas bem singulares:

Sujeito 1: Tive muita dificuldade até pegar o ritmo de estudo. Tava há muito tempo sem estudar, aí o começo foi difícil.

Sujeito 2: Devia ter feito um curso de português antes pra poder fazer. Não aprendi muita coisa. Fiz o ensino médio no polo, lá antes era uma escola de ensino médio e era um ensino fraco, sabe?!

Sujeito 5: No começo parecia que os textos eram em chinês (risos). Eu perguntava pro tutor, ele mandava eu lê com o dicionário do lado. Aí eu num tinha, ganhei. Mais aí vi que no google é só digitar a palavra que você descobre bem facinho. Mas foi molenão, porque até o meu português não era bom. Como disse a tutora, "falta base em vocês". 
É preciso pensar na qualidade do ensino fundamental e do ensino médio para entender o perfil acadêmico do aluno que cursa um nível superior no Brasil. Sabemos que a educação em vários lugares do país apresenta dificuldades em diversas áreas. Desse modo, se faz necessária uma discussão por parte dos educadores e também a implemntação de políticas públicas adequadas, com o intuito de elevar a qualidade desse ensino. Esforços não podem ser poupados para que tenhamos uma evolução no âmbito da educação básica, que se divide em ensino fundamental e médio e, por conseguinte, também na educação superior.

O quadro a seguir organiza os conteudos verbalizados, o discurso direto e os elementos identificados nas vozes que perpassam as dificuldades acadêmicas. A fim de se analisar o discurso dos entrevistados com maior organização, o quadro apresenta as vozes dos discursos trazendo a intertextualidade, o dicurso direto, o discurso indireto e a pressuposição de que, a partir das palavras, serão objetos de reflexão durante a análise dos dados da pesquisa.

\section{QUADRO 2 - Perfil Acadêmico}

\section{Unidade temática: Dificuldades Acadêmicas}

\section{Vozes Representadas: estudantes de Carinhanha - BA Ped. - FE-UnB/UAB}

\begin{tabular}{|c|c|c|}
\hline $\begin{array}{c}\text { Conteúdos verbalizados } \\
\text { Discurso Direto }\end{array}$ & Discurso Indireto & $\begin{array}{c}\text { Pressuposição: Elementos } \\
\text { identificados nas vozes que } \\
\text { perpassam as dificuldades } \\
\text { acadêmicas }\end{array}$ \\
\hline $\begin{array}{l}\text { “Mas foi mole não porque até } \\
\text { o meu português não era bom.' } \\
\text { Tava há muito tempo sem } \\
\text { estudar." } \\
\text { "Devia ter feito um curso de } \\
\text { português antes pra poder } \\
\text { fazer". }\end{array}$ & $\begin{array}{l}\text { Formação acadêmica } \\
\text { interrompida. } \\
\text { Falha nas modalidades } \\
\text { educativas anteriores. }\end{array}$ & $\begin{array}{l}\text { Ensino frágil necessitando de } \\
\text { reformas de cunho político- } \\
\text { educacional; } \\
\text { Ciclo educacional quebrado } \\
\text { no nível superior por fatores } \\
\text { pessoais e sociais intrínsecos } \\
\text { ao sujeito. }\end{array}$ \\
\hline
\end{tabular}

Todos esses fatores estavam presentes na realidade do sujeito que teve sua trajetória acadêmica permeada por essa realidade. A questão da quebra do ciclo acadêmico do jovem 
tem acontecido com frequencia e no caso do homem esse índice é maior de acordo com dados do IBGE, de 2010, correspondendo a 40\% enquanto que o indice de abondono de estudo das mulheres é de 32\%. Ainda de acordo com os dados do IBGE de 2010, as pessoas sem instrução ou com o fundamental incompleto representaram $49,3 \%$ da população. O total de pessoas sem instrução ou com o fundamental incompleto ficou em 44,2\%, em área urbana, e em 79,6\%, em área rural.

Essa quebra no ciclo educacional representa um atraso para o estudante, e quando há a retomada dos estudos, sempre é mais difícil a adaptação do aluno que, por conseguinte, enfrenta grandes dificuldades para acompanhar o curso e se manter estudando.

De acordo com a Agência Brasil de Comunicação (EBC), o Brasil tem mantido uma pouco alentadora posição nas avaliações do Programa Internacional de Avaliação de Estudantes (Pisa) e em suas três áreas de pesquisa de desempenho: leitura, ciências e matemática. Em 2012, o Brasil ficou em 58º entre 65 países avaliados. Foi ressaltado também que, no Brasil, menos de $2 \%$ dos estudantes atingiram a totalidade dos pontos na solução dos problemas apresentados.

Dada essa realidade cabe questionarmos criticamente a qualidade da educação oferecida no âmbito da escola pública. A fim de levantarmos as fragilidades existentes, procurando soluções para essas questões no campo da pesquisa, é necessário criar espaços de reflexão de modo a que todos os atores envolvidos com o processo educacional possam contribuir para o debate: desde o gestor da política pública, que articula as matérias educacionais no âmbito político, até os profissionais que exercem seu ofício no solo da escola. É na escola que a teoria se transforma em prática, necessitando estar alicerçada e respaldada em um e por um fazer pedagógico sério e comprometido em oferecer uma educação de qualidade. Por isso, todos esses atores devem se articular. Ter uma gestão séria de políticas públicas, professores capacitados e escolas bem preparadas devem ser o objetivo de um país que deseja ver transformações sociais por meio de uma educação crítica que vise antes de tudo a emancipação, social e política.

\subsection{A influência econômica na formação do estudante}

As limitações econômicas e as dificuldades na trajetória educacional foram elementos presentes nesta pesquisa. Superação, esforço, dedicação e sacrifício foram relatados pelos estudantes como elementos presentes em suas conquistas educacionais. 
Sujeito 1: Foi minha avó, com o sonho de ter um neto formado. Ela investia a aposentadoria dela em mim e pagou a prestação de um notebook pra me ajudar. É pra ela o diploma que conquistei.

Sujeito 2: Corri muito atrás. Além de ser professora, era cabelereira e manicure em Carinhanha e nas Agrovilas. Tudo que conseguia era pros meus filhos e pra esse curso. Sol a sol, domingo a domingo, dei duro e consegui comprar meu computador.

Sujeito 5: Passei muito aperto pra tá onde tô hoje. Deixava de lanchar pra pagar lan house. As vezes o tutor falava-“nossa, tá ruim, você precisa melhorar suas atividades" - e eles não sabem que o ruim pra eles era o meu máximo.

A questão da família e do trabalho com uma carga massante fez parte da trajetória desses sujeitos.

Sujeito 1: Capinei muito terreiro em Carinhanha desde moleque. Trabalhava na creche, na roça. O começo do curso foi difícil, ainda não tava contratado pela prefeitura. Agora melhorou muito. Cansaço eu tinha na época, mas não me arrependo de nada e faria tudo de novo.

Sujeito 6: Meu pai era caminhoneiro, ai sumia mesmo, fazia um filho e ia embora. (risos). Nesse vai e vem foram 14, mamãe quase morreu de parir e trabalhava na roça com os meus avós.(...) Minha infância foi vendendo verdura com meu avô. Estudar era difícil, mas a gente ia pra escola. Tinha uma escola só. E mainha fazia questão que todos nós frequentássemos. E é por ela que eu luto até hoje, corro atrás, sabe, desisto não, e não vou querer que meus filhos tenham a infância que eu tive. É para isso que eu estudo: para eles terem uma vida melhor que eu. Pra mim é uma oportunidade maravilhosa fazer esse curso a distância.

Esse sentimento de orgulho frente ao êxito que obtiveram marcou a fala dos sujeitos em diversos momentos. Apesar de a estudante ser oriunda de uma família de classe baixa, que não teve as mesmas oportunidades, ela conseguiu chegar até o nível superior, mesmo com pouco capital cultural herdado. Esse fator não foi impeditivo, mas, sim, um estímulo para que 
ela galgasse um futuro diferente. Mesmo em face à falta de oportunidades que seus pais e avós enfrentaram, houve uma quebra dessa dinâmica.

Oportunizar meios e ações para que todos tenham acesso à educação é o papel de um ensino democratizador que atende com qualidade o aluno que necessita estudar e requer esforços de todas as áreas para evoluir e progredir em seu processo educacional.

QUADRO 3 - Influência ecônomica na formação do estudante

\section{Unidade temática: Questões socioeconômicas}

Vozes Representadas: Estudantes de Carinhanha - BA Ped. - FE-UnB/ UAB

\begin{tabular}{|c|c|c|}
\hline $\begin{array}{c}\text { Conteúdos verbalizados } \\
\text { Discurso Direto }\end{array}$ & Discurso Indireto & $\begin{array}{l}\text { Análise Crítica: } \\
\text { Elementos } \\
\text { identificados nas } \\
\text { vozes que } \\
\text { perpassam as } \\
\text { questões } \\
\text { socioeconômicas }\end{array}$ \\
\hline "Capinei muito terreiro em & & \\
\hline $\begin{array}{l}\text { Carinhanha desde moleque. } \\
\text { Trabalhava na creche, na roça. } \\
\text { o começo do curso foi difícil, } \\
\text { ainda não tava contratado pela } \\
\text { prefeitura. Agora melhorou } \\
\text { muito. Cansaço eu tinha na } \\
\text { época, mas não me arrependo de } \\
\text { nada e faria tudo de novo". }\end{array}$ & $\begin{array}{l}\text { Dificuldades financeiras. } \\
\text { Atuava em mais de uma profissão } \\
\text { com muitos papéis sociais. } \\
\text { Cansaço físico durante o curso. } \\
\text { A família impulsionando o } \\
\text { estudante. }\end{array}$ & $\begin{array}{l}\text { A questão da } \\
\text { dificuldade na } \\
\text { infância. } \\
\text { Questão de gênero } \\
\text { (a figura da mulher } \\
\text { lutando por sua } \\
\text { família). } \\
\text { A superação dos } \\
\text { estudantes quanto } \\
\text { aos esforços para } \\
\text { alcançar seus } \\
\text { objetivos. }\end{array}$ \\
\hline
\end{tabular}


os meus avós.(...) Minha infância foi vendendo verdura com meu avô. Estudar era difícil, mas a gente ia pra escola. Tinha uma escola só. E mainha fazia questão que todos nós frequentássemos. E é por ela que eu luto até hoje, corro atrás, sabe, desisto não, e não vou querer que meus filhos tenham a infância que eu tive. É para isso que eu estudo: para eles terem uma vida melhor que eu. Pra mim é uma oportunidade maravilhosa fazer esse curso a distância.

A questão da superação e da produção do sucesso escolar para que esses indivíduos conseguissem chegar ao diploma foi decissivo em alguns casos e signficou ascenção para eles. O sucesso desses estudantes foi impulsionado por diversas razões, principalmente a família, que o auxiliou. Esta pesquisa coincide, nesses pontos, com o estudo de Bandera (2014, p. 2):

\footnotetext{
Os pais, nesse aspecto, são os primeiros a ter a necessidade objetiva - e, paralelamente, a vontade subjetiva - de acumular capital cultural e simbólico, convertendo parte do capital econômico dos avós e se aproximando, assim, das posições de maior prestígio na sociedade brasileira, tais como as profissões liberais.
}

A avó converteu o capital econômico que ela possuía em capital cultural para o seu neto, tendo o objetivo de vê-lo formado e com uma profissão que o qualificasse para o mercado de trabalho. Embora esse aspecto - maior capital cultural - não seja a garantia para a ascenção social de sujeitos das classes populares, ele abre possibilidades para a formação continuada e sintonia às novas demandas sociais e econômicas da atualidade. 
A questão da conscientização desses estudantes, assumindo o estudo como uma prioridade mesmo em face de inúmeros afazeres, é possível ser observada em suas falas. Houve esforços e incentivos em se criar meios e ações para que a educação fosse priorizada e que eles superassem as dificuldades em prol de seu futuro. Este futuro, em alguns casos promissor, está diretamente relacionado ao sucesso escolar no imaginário do estudante. É na escolarização que se vislumbra o sucesso e é a obtenção de diplomas que os estudantes e suas famílias enxergam como passo importante na ascensão social. Nesse aspecto, entendem que é por meio da acumulação de capital cultural e simbólico, com a conclusão do curso superior, que vai se dar a modificação em suas condições de vida. Entretanto, sabe-se, isso não se transformará numa realidade para todos. A conclusão de um curso superior, por si só, não garante um futuro de sucesso, tampouco a entrada no mercado de trabalho.

5.7 Perfil sociointeracional: relacionamento com os colegas, tutores e professores durante o curso de Pedagogia

O relacionamento com os tutores, professores e colegas, de acordo com os estudantes, foi muito bom e os egressos em sua maioria tem uma ligação afetiva forte com o polo e os professores.

Sujeito 1: Ah...os tutores estavam presentes o tempo todinho, dando força. Se eu mandava uma mensagem era rapidinho que eles respondiam. A maioria deles trabalhou muito bem. Eu não sentia distância na educação a distância.

Sujeito 3: A tutora presencial é antes de tudo uma amiga, em todo o tempo.

Sujeito 4: O tutor " $x$ ” vem pra nossa formatura.Tô louca para dar um abraço nele. Pessoa maravilhosa (...)

Sujeito 5: Foi a professora "x" que me fez acreditar que meu sonho era possível. Devo a ela, e principalmente a minha família, o que eu conquistei. Acho que se eu não tivesse tido esse contato tão próximo com essa professora me incentivando não sei se eu iria ter conseguido (....). 
Sujeito 6: A nossa turma era muito unida em todos os momentos;

Sujeito 7: Quando não podia ir ao polo usava a internet da minha amiga do curso.

Parceria, confiança e credibilidade são essenciais. Educar a distância demanda conhecimento e esforço por parte de quem aprende ou ensina. Logo, o desempenho dos professores e tutores deve levar em conta todas as peculiaridades desse ensino, possibilitando as trocas de maneira colaborativa, para que a aprendizagem se desenvolva da melhor maneira possível, fazendo com que esse estudante se sinta acolhido e acompanhado. Faz-se necessário que esses profissionais orientem, acompanhem e façam o processo de mediação, facilitando o "estar junto virtual" ${ }^{11} \mathrm{e}$, desse modo, amparando o aluno em todos os momentos, colaborando positivamente na caminhada que o estudante percorrerá.

No caso desses egressos, a figura do tutor teve grande influência e se destacou, merecendo um espaço de discussão no trabalho, pois suas contribuições foram essenciais. Sabemos que se o estudante se sentir acompanhado a chance de evasão é bem menor. Segundo Gonzalez (2005), o tutor é o profissional que mais tem contato com os alunos e sua principal função é prevenir a evasão. Gonzalez (2005, p. 46) aponta alguns motivos para essa evasão:

\begin{abstract}
Existem várias razões pelas quais um aluno abandona um curso a distância, iniciado com uma visível empolgação e entusiasmo. Os especialistas são unânimes em dizer que as causas da evasão do ensino a distância são muito diferentes daquelas ocorridas no ensino presencial. Isso reforça a percepção de que os fatores motivacionais ou desmotivacionais estão presentes em toda e qualquer interatividade humana.
\end{abstract}

Não existe educação sem contato humano, sem troca e sem o devido acompanhamento. Gonzalez (2005) é enfático nisso e aponta a tutoria como peça fundamental para a aprendizagem do aluno da EAD. Segundo o autor, as mensagens postadas pelo tutor e as trocas que ele estabelece com os alunos costuma motivá-los a um alto nível de participação. O autor aponta também que o tutor deve descobrir os fatores motivacionais que levam os alunos a aprender. Para Gonzalez (2005, p. 46) esse tutor deverá adotar uma postura de "animador, apresentando o curso de uma maneira lúdica e criativa e propiciando a interação contínua entre todos os envolvidos", e conclui:

8 Estar junto virtual: Acompanhar a caminhada do aluno em todos os momentos do curso (VALENTE e BUSTAMANTE, 2009). 
É necessário, portanto, que o professor empregue todos os recursos possíveis de interação, sejam eles síncronos, assíncronos, como: correspondência, email, fórum de discussão, bate-papos (chats), listas de discussão, murais virtuais, teleconferência e videoconferência, para que os alunos troquem ideias, estabeleçam relações afetivas e motivem-se reciprocamente.

Os tutores, quando utilizam todas essas ferramentas, se aproximam dos alunos, estabelecendo uma relação mútua de troca e cumplicidade. $\mathrm{O}$ conhecimento é um processo e o tutor deve propiciar isso de maneira aprazível. A figura do tutor é sim de grande relevância nessa modalidade.

\section{QUADRO 4 - Perfil sociointeracional}

\section{Unidade temática: relacionamento com os colegas, tutores e professores}

Vozes Representadas: estudantes de Carinhanha - BA Ped. - FE-UnB/UAB

\begin{tabular}{|c|c|c|}
\hline Discu & to & $\begin{array}{c}\text { Pressuposição: Elementos } \\
\text { identificados nas vozes que } \\
\text { perpassam o relacionamento } \\
\text { com colegas, tutores e } \\
\text { professores }\end{array}$ \\
\hline $\begin{array}{l}\text { "Acho que se eu não tivess } \\
\text { esse contato tão próximo } \\
\text { com essa professora me } \\
\text { incentivando não sei se eu } \\
\text { iria ter conseguido.” } \\
\text { "A tutora presencial é antes } \\
\text { de tudo uma amiga, } \\
\text { em todo o tempo." } \\
\text { "Os tutores estavam } \\
\text { presentes o tempo todinho." } \\
\text { "A nossa turma era muito } \\
\text { unida em todos os momentos. } \\
\text { "Quando não podia ir ao } \\
\text { polo usava a internet da } \\
\text { minha amiga do curso." }\end{array}$ & $\begin{array}{l}\text { Importância } \\
\text { relacionamento entre colegas, } \\
\text { tutores e professores } \\
\text { supervisores. } \\
\text { Amizade como fator } \\
\text { importante. } \\
\text { A constante presença dos } \\
\text { tutores e professores, } \\
\text { contribuindo para o sucesso. } \\
\text { Parceria entre os atores } \\
\text { envolvidos com o processo } \\
\text { educacional dos discentes. } \\
\text { A questão da proximidade } \\
\text { entre os pares: alunos, tutores } \\
\text { e professores em uma relação } \\
\text { amistosa. }\end{array}$ & $\begin{array}{l}\text { A afetividade como fator } \\
\text { preponderante para o sucesso } \\
\text { acadêmico. } \\
\text { A necessidade de } \\
\text { acompanhamento do aluno } \\
\text { que estuda a distância. } \\
\text { A educação a distância } \\
\text { rompendo barreiras } \\
\text { geográficas, sociais } \\
\text { tecnológicas, democratizando } \\
\text { o ensino e trazendo-o para } \\
\text { perto do aluno, que se sente } \\
\text { acompanhado afetivamente e } \\
\text { academicamente. }\end{array}$ \\
\hline
\end{tabular}


\begin{tabular}{l|l|l}
\hline “O tutor 'X' vem pra & & \\
nossa formatura. Tô louca & & \\
para dar um abraço nele, & & \\
pessoa maravilhosa." & & \\
"Eu não sentia distância & & \\
na educação a distância." & & \\
\hline
\end{tabular}

Parceria e confiança entre os pares são requisitos fundamentais para o sucesso acadêmico na modalidade a distância. A aproximação física e emocional dos sujeitos consegue romper a lógica do ensino mediado por máquinas. E é por meio da interatividade em uma relação dialógica, sistêmica e de proximidade que se consegue chegar mais profundamente ao aluno.

Os sujeitos da pesquisa se sentiram acolhidos em uma educação a distância que se fez próxima e de acordo com suas necessidades. $\mathrm{O}$ educador, quando consegue romper com essas distâncias, ressignifica a sua prática docente em atitudes humanas que tornam o fazer pedagógico simples e assertivo em um sistema de colaboração mútua entre os pares. Isso, certamente, contribui para o êxito do aprendizado, pois faz com que os alunos se sintam acompanhados e acolhidos em todos os momentos do curso.

5.8 Desigualdade, pobreza e políticas sociais

Quando foi indagada aos egressos a questão das desigualdades, em algumas entrevistas houve silêncio ou respostas bem atreladas ao senso comum. Já em outras há uma concepção arraigada do que essa desigualdade significa com conceitos amargos e confusos.

Silêncio, pois alguns não desenvolveram ideias a respeito do que fora solicitado. Outros vincularam a questão da desigualdade a uma análise da própria vida, demonstrando sofrimento e também um sentimento de inferioridade frente aos eventos que os afligiam.

Sujeito 3: A desigualdade aqui tem e o povo gosta, porque vive de bolsa isso, bolsa aquilo. Os pais dos alunos nas escolas onde eu trabalho é assim. Faz bico aqui e ali. Aí como é que 
melhora isso? Pra mim alimenta a desigualdade, pois não se esforça para melhorar e a educação sozinha não pode mudar isso.

Sujeito 4: Eu sempre sofri desigualdade, né?! Meu pai veio pra Brasília e o pessoal diz que lá ele tem mulher e outros filhos. Moro só com minha mãe e avó e vi minha mãe fazer de tudo, tudo mesmo pra me sustentar. Porque, assim, eu tenho primo aqui em Carinhanha que casou com parente de político e vive diferente. Já eu, mainha e voinha vivemos na desigualdade pois não temos as mesmas coisas.

Os sujeitos criticam as políticas sociais existentes no governo atualmente e colocam isso como um fator de acomodação para a população. Há ainda o fato de o sucesso pessoal estar atrelado a unicamente esforços próprios e não se dimensionar uma estrutura maior por detrás que oprime a população e a escraviza em um sistema de dominação, subjugação e alienação. Uma educação emancipadora, crítica e libertária deve estar em pauta para se combater a desigualdade e se enxergar além das amarras sociais.

Preparar cidadãos críticos, atuantes, politizados, que consigam se articular em redes, firmar parcerias e exigir ações governamentais concretas, deve ser o objetivo da educação crítica que levará à emancipação dos indivíduos não só de Carinhanha, mas também de todo o Brasil.

Diante de tal realidade, vemos que o país avançou quanto à democratização do ensino, mas há ainda um longo caminho a percorrer e o investimento em educação tem seu valor, pois eleva o nível de escolarização, tornando a sociedade mais igual e a distribuição de renda mais justa.

O abandono paterno também marcou as vivências de uma das entrevistadas. Infelizmente isso é uma realidade comum, questões de gênero ainda se perpetuam e a figura da mulher é retratada em diversos lares como a única mantenedora responsável pelos rendimentos domésticos. 
QUADRO 5: Desigualdade, pobreza e políticas sociais

\section{Unidade temática: desigualdade social}

Vozes Representadas: estudantes de Carinhanha - BA Ped. - FE-UnB/ UAB

\begin{tabular}{|c|c|c|}
\hline $\begin{array}{c}\text { Conteúdos verbalizados } \\
\text { Discurso Direto }\end{array}$ & Discurso Indireto & $\begin{array}{c}\text { Análise Crítica: } \\
\text { Elementos identificados nas } \\
\text { vozes que perpassam as } \\
\text { questões das desigualdades } \\
\text { sociais } \\
\end{array}$ \\
\hline $\begin{array}{l}\text { "Meu pai veio pra Brasília } \\
\text { e o pessoal diz que lá ele } \\
\text { tem mulher e outros filhos. } \\
\text { Moro só com minha mãe e } \\
\text { avó e vi minha mãe fazer de } \\
\text { tudo, tudo mesmo pra me } \\
\text { sustentar. Porque, assim, eu } \\
\text { tenho primo aqui em } \\
\text { Carinhanha que casou com } \\
\text { parente de político e vive } \\
\text { diferente. Já eu, mainha e } \\
\text { voinha vivemos na } \\
\text { desigualdade, pois não } \\
\text { temos as mesmas coisas.” } \\
\text { “A desigualdade aqui tem e o } \\
\text { povo gosta, porque vive de } \\
\text { bolsa isso, bolsa aquilo.” }\end{array}$ & $\begin{array}{l}\text { Sentimento de tristeza frente } \\
\text { ao abandono familiar; } \\
\text { Descrédito com as políticas } \\
\text { sociais oferecidas pelo } \\
\text { governo federal. }\end{array}$ & $\begin{array}{l}\text { A questão de gênero também } \\
\text { se faz presente, com o } \\
\text { abandono do pai, ficando a } \\
\text { cargo apenas da mãe } \\
\text { sustentar a casa. } \\
\text { Senso comum atrelado às } \\
\text { políticas públicas de cunho } \\
\text { social. }\end{array}$ \\
\hline
\end{tabular}

Sabemos que os pobres não poucas vezes são submetidos a situações de privação em várias áreas, como alimentação, transporte, saúde, educação etc. Há necessidade de uma verdadeira efetivação de políticas públicas que oportunizem mecanismos e ações favoráveis para o crescimento dessa parte da população, que também sofre com as desigualdades, conforme ressalta Aguiar e Araujo retratando a América Latina (2002, p. 17):

Por tanto, los pobres están sometidos a situaciones de privación de capacidades. Los ejemplos son abundantes: trabajadores rurales 
itinerantes y víctimas del frío o la seca obligados a dejar su tierra natal para sobrevivir; el trabajo infantil impuesto a las familias por una cuestión de vida o muerte; falta de acceso o acceso a educación y salud de mala calidad..

Essas privações são impeditivos para que o sujeito consiga se integrar adequadamente à sociedade. Portanto, o acesso às políticas sociais deve ser universalizado, visando a diminuição da desigualdade. No entanto, é preciso ressaltar que, muitas vezes, essas políticas não alcancam a totalidade, e a desigualdade e a probreza continuam existindo. Além disso, há uma desestruturação também das próprias políticas públicas oferecidas pelo governo federal, o que contribui para a manutenção da situação de privação e de não aproveitamento pleno do aprendizado pelo indivíduo.

A educação crítica e emancipadora deve ser o foco de professores sérios e comprometidos que educam para um despertar quanto à propria situação social na qual o sujeito se encontra.

5.9 A inclusão tecnológica dos estudantes de Carinhanha - BA

O perfil tecnológico dos sujeitos entrevistados apresenta o contato com o computador no momento em que se tornaram estudantes da Universidade de Brasília na modalidade a distância. A inserção tecnologia foi permeada por dificuldades, no manuseio do computador.

Sujeito 1: Haha... era difícil mesmo porque computador só fui ver quando entrei no curso. Antes eu nem lembrava que ele existia. A gente, sabe né, que nem tem,nem todo mundo pode ter computador... Aí eu fazia parte dessa população que não podia ter, mas tive que ter pra poder estudar a distância.

Sueito 4: Desafio maior foi ter que estudar com o computador até eu me acostumar criar a disciplina. Os professores e tutores ajudaram muito, mas eu tinha dificuldade no início.

Sujeito 6: Mexer, mexer quem mexia era meu filho, ele fez até um facebook pra mim antes de eu entrar no curso. Mas mexer sozinha mesmo foi só depois do curso. 
Sujeito 7: $O$ acesso para mim era dificil. E nem dinheiro para ter um computador... mas, com o tempo, vi que ele era importante e sem as tecnologias a gente fica desinformado das notícias.

Houve uma incorporação de novas ferramentas com o uso do computador que favoreceu o sujeito. De acordo com Sancho e Hernandez (2006, p. 15): "O uso do computador não se reduz apenas ao ponto de vista prático da utilização de aplicações informáticas, mas também da perspectiva teórica, crítica, filosófica e social do que representa para a sociedade a incorporação de uma nova ferramenta".

O fato também do estudante não ter condições financeiras para ter um computador, nem tempo para utilizá-lo, marcou a fala do sujeito 7 e se faz presente no dicurso dele. Cabe analisarmos a questão da exclusão tecnológica, que traz dificuldades para o indivíduo se relacionar na sociedade e obter informações por intermédio das tecnologias. A exclusão digital vem acompanhada de outras formas de desigualdade conforme ressalta Sorj (2003, p. 59):

\begin{abstract}
A exclusão digital possui forte correlação com outras formas de desigualdade social, e, em geral, as taxas mais altas de exclusão digital encontram-se nos setores de menor renda. As desigualdades sociais no campo das comunicações, na sociedade moderna de consumo de massas, não se expressa somente no acesso ao bem material - rádio, telefone, televisão, Internet -, mas também na capacidade do usuário de retirar, a partir de sua capacidade intelectuale profissional, o máximo de proveito das potencialidades oferecidas por cada instrumento de comunicação e informação.
\end{abstract}

Pensar em educação a distância é refletir sobre o perfil tecnológico do estudante, que tem acesso ao computador em alguns casos apenas quando vai lidar com essa modalidade educativa. Dada essa realidade, é preciso questionarmos também sobre a exclusão tecnológica e entendê-la como desdobramento e ramificação de outras formas de exclusão.

A educação tecnológica auxilia na expansão do campo de visão dos alunos em diversos aspectos. Esse estudante, que antes não tinha acesso ao ensino, vê no domínio das modernas tecnologias um passo fundamental no caminho para o estudo. Assim, o conhecimento da tecnologia, em destaque no cenário social, modifica o modo como o aluno vê o aprendizado e na forma como ele próprio se vê no processo de obtenção de tal conhecimento.

A criação desses espaços educativos por meio da tecnologia tem sua relevância no cenario educacional brasileiro, pois, por intermédio das tecnologias, se pode criar espaços para a difusão de conhecimentos desenvolvidos em instituições educaionais sérias, como é o caso da Universidade de Brasília. Um dos desafios da modalidade de ensino a distância diz 
respeito ao acompanhamento do aluno em seu processo de aquisição do conhecimento. A orientação e a aproximação contínuas tornam possível uma educação dialógica e esse deve ser o foco da educação a distância.

\section{QUADRO 6- A inclusão tecnológica dos estudantes de Carinhanha - BA}

\section{Unidade temática: dificuldades ligadas à inserção do sujeito no uso das tecnologias}

Vozes Representadas: estudantes de Carinhanha - BA Ped. - FE-UnB/ UAB

\begin{tabular}{|c|c|c|}
\hline $\begin{array}{l}\text { Conteúdos verbalizados } \\
\text { Discurso Direto }\end{array}$ & Discurso Indireto & $\begin{array}{c}\text { Pressuposição: Elementos } \\
\text { identificados nas vozes que } \\
\text { perpassam as dificuldades } \\
\text { tecnológicas }\end{array}$ \\
\hline $\begin{array}{l}\text { "Computador mesmo só } \\
\text { fui ver quando entrei no } \\
\text { curso." } \\
\text { "Mas mexer sozinha mesmo } \\
\text { foi só depois do curso.” } \\
\text { "A gente sabe, né, que } \\
\text { tem tecnologia, mas nem } \\
\text { todo mundo pode } \\
\text { ter computador.Aí eu fazia } \\
\text { parte dessa população que } \\
\text { não podia ter, mas tive que } \\
\text { ter pra poder estudar a } \\
\text { distância." } \\
\text { "Fui aprender a mexer } \\
\text { com o computador com o } \\
\text { curso, né?!" } \\
\text { "[...]e nem dinheiro para } \\
\text { ter um computador, mas } \\
\text { com o tempo vi que ele } \\
\text { era importante e sem o }\end{array}$ & $\begin{array}{l}\text { Falta de acesso a computador } \\
\text { por } \\
\text { socioeconômicas; } \\
\text { Exclusão tecnológica; } \\
\text { Inclusão tecnológica por } \\
\text { intermédio do curso; } \\
\text { Exclusão informacional. } \\
\text { Pouca familiaridade com a } \\
\text { educação tecnológica. }\end{array}$ & $\begin{array}{l}\text { Questões socioeconômicas } \\
\text { que interferem no processo } \\
\text { de aquisição do } \\
\text { conhecimento por parte dos } \\
\text { estudantes. } \\
\text { Cultura informacional } \\
\text { tecnológica pouco difundida, } \\
\text { pela falta de acesso e } \\
\text { conhecimento por parte da } \\
\text { população. } \\
\text { Acesso à tecnologia limitada } \\
\text { por questões econômicas. } \\
\text { Desconhecimento } \\
\text { ferramentas tecnológicas. }\end{array}$ \\
\hline
\end{tabular}




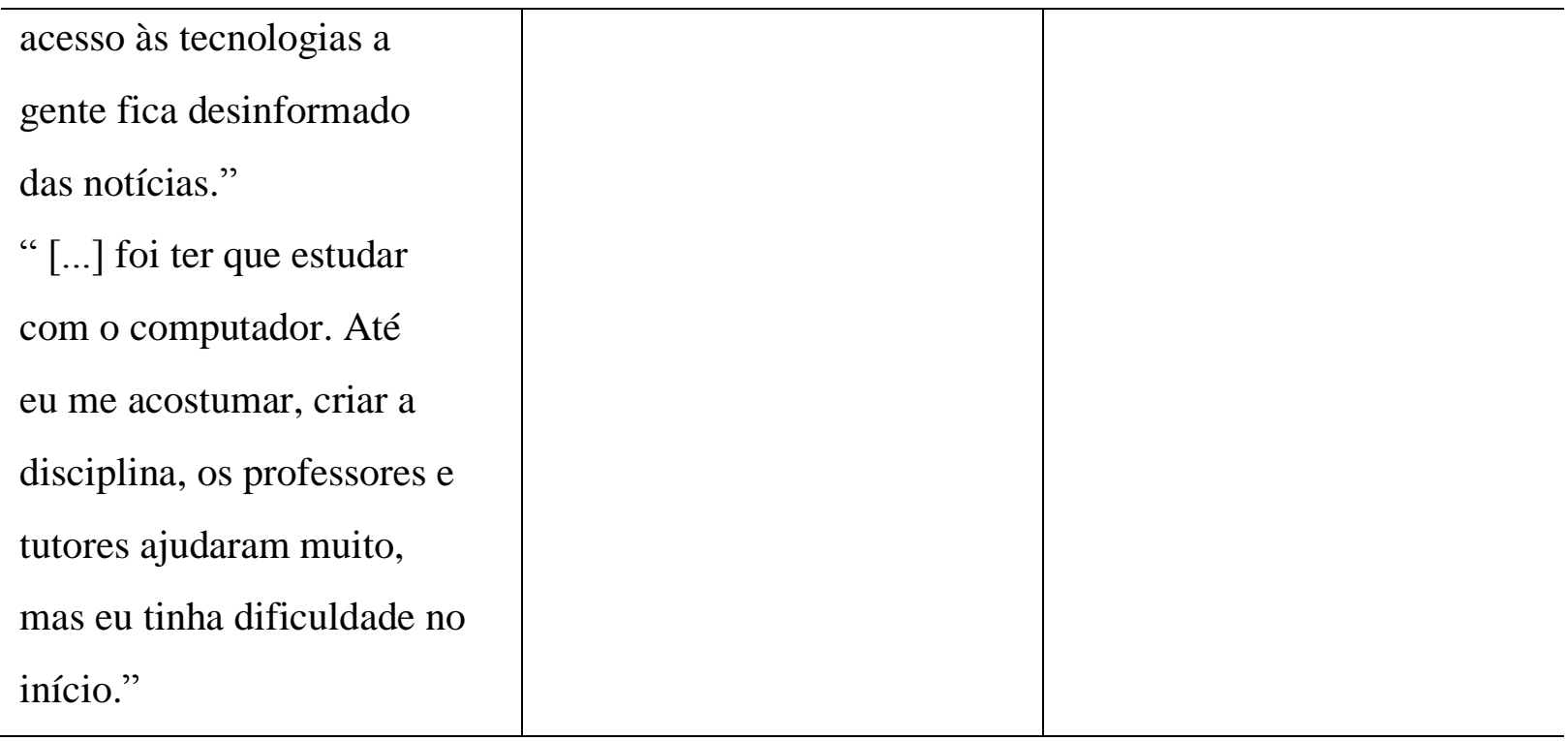

A questão da desigualdade informacional se faz presente em divesos contextos socioeconômicos e se materializa no discurso do sujeito com muita clareza. Não somente a falta do aparato tecnológico e do computador em si mas também o domínio do uso das ferramentas tecnológicas são motivos para a exclusão tecnológica.

A educação a distância requer sujeitos aptos para o manejo tecnológico. Diante disso, cabe analisarmos com mais profundidade a questão das desigualdades informacionais. Poder fazer uso das tecnologias tem um custo. Atualmente a tecnologia móvel, oferecida pelo celular, tem grande destaque no cenário tecnológico brasileiro. Adquirir um celular, hoje, está facilitado por rede de telefonias que desejam se manter no mercado com hegemonia e uma certa solidez. Para isso, oferecem aos clientes pacotes acessíveis com celulares que, na maioria dos casos, já vem programado para o uso da internet.

No caso da educação tecnológica, estudar pelo celular, não é muito confortável para o aluno, devido ao tamanho da visualização, mas não deixa também de ser um recurso a mais para o estudante.

Tanto para se obter um celular quanto para se obter um computador, o custo financeiro pode ser um impeditivo para o aluno que vai estudar à distância. Esse é um dos fatores da evasão do ensino a distância.

As desigualdades são reais e afligem os países pobres ${ }^{12}$, que ainda necessitam de investimentos nas áreas sociais, educacionais, informacionais e, por conseguinte,

\footnotetext{
12 A desigualdade social é um dos principais problemas brasileiros, pois, apesar de o país estar entre as 10 maiores economias do mundo (conforme dados obtidos no portal da FUNAG - Fundação Alexandre de Gusmão - em janeiro de 2015), ainda tem muito a resolver no que diz respeito a questões como acesso à alimentação, educação e saúde, por exemplo.
} 
tecnológicas. Essa dificuldade de acesso à informação tecnológica impõe a necessidade de um debate que deve permear as áreas econômicas, sociais, tecnológicas e informacionais, pois influi em todos os âmbitos da vida social, incluindo o escolar.

Dessa maneira, incentivar e requerer a implantação de laboratórios de informática nas escolas e a qualificação dos professores para atender a essas demandas se faz necessário. Criar oportunidades e meios para que o sujeito tenha acesso às tecnologias é importante para que ele seja alfabetizado tecnologicamente e saiba utilizar tais ferramentas a seu favor.

\subsection{Deficiência na infraestrutura do polo}

Quando indagados sobre a questão da infraestrutura do polo, os estudantes se referiram à oferta tecnológica do local como sendo precária e frágil, demostrando um descontentamento quanto a esse aspecto essencial para a modalidade de ensino escolhida para a continuidade de seus estudos. O fato da internet do polo não ser de qualidade foi bastante marcado nas respostas dos estudantes, revelando um sistema ainda frágil que, por mais que ofereça um ensino democratizador, ainda peca quanto à infraestutura que oferece ao aluno.

Sujeito 2: A internet do polo cai muito. Os tutores pedem pra gente vir e a gente passa raiva aqui nesse polo.

Sujeito 3: Eu atrasei muitos trabalhos, mas me virava pra dar conta. Posso falar que além da dificuldade da falta de dinheiro que enfrentei durante todo o curso, a questão do computador e do acesso à internet foram os meus maiores dificultadores.

Sujeito 4: A maior falha mesmo foi que o polo, que era para atender bem, às vezes não atendia por causa da internet.

Sujeito 6: Fui ter acesso à internet aqui no polo, e isso foi minha maior dificuldade. No começo do curso meu único meio de ter acesso à internet era aqui no polo.

O questionário também trouxe a questão da precariedade do polo de maneira clara, pois das 25 respostas elucidadas, 13 sujeitos colocaram como difícil a questão do uso da internet. A falta de acesso à internet, essencial para a aprendizagem do aluno, é preocupante, 
já que a educação a distância tem como uma de suas bases a comunicação entre o professor e o aluno por meio de recursos que permitem o contato à distância. Se essa comunicação é feita em condições precárias, a aprendizagem também é prejudicada.

QUADRO 7- Deficiência na infraestrutura do polo

Unidade temática: acesso à tecnologia

Vozes representadas: estudantes de Carinhanha - BA Ped. - FE- UnB / UAB

\begin{tabular}{|c|c|c|}
\hline $\begin{array}{c}\text { Conteúdos verbalizados } \\
\text { Discurso Direto }\end{array}$ & Discurso Indireto & $\begin{array}{l}\text { Análise crítica: elementos } \\
\text { identificados nas vozes que } \\
\text { perpassam o acesso à internet }\end{array}$ \\
\hline $\begin{array}{l}\text { "A internet do polo cai muito. } \\
\text { Os tutores pedem pra gente } \\
\text { vir e a gente passa raiva aqui } \\
\text { nesse polo." } \\
\text { "Eu atrasei muitos trabalhos, } \\
\text { me virava pra dar conta. Posso } \\
\text { falar que, além da } \\
\text { dificuldade da falta de } \\
\text { dinheiro que enfrentei durante } \\
\text { o curso, a questão do } \\
\text { computador e do acesso à } \\
\text { internet foram os meus } \\
\text { maiores dificultadores." } \\
\text { "A maior falha mesmo foi } \\
\text { que o polo, que era para } \\
\text { atender bem, às vezes não } \\
\text { atendia por causa da internet." } \\
\text { "Fui ter acesso à internet } \\
\text { aqui no polo e isso foi minha } \\
\text { maior dificuldade. No }\end{array}$ & $\begin{array}{l}\text { Descontentamento com a } \\
\text { estrutura oferecida; } \\
\text { Impaciência com o acesso } \\
\text { tecnológico do polo; }\end{array}$ & $\begin{array}{l}\text { A questão do acesso à } \\
\text { tecnologia está ligada a um } \\
\text { capital que não possuíam, } \\
\text { antes de terem acesso à } \\
\text { UnB - UAB. } \\
\text { Os sujeitos vivenciavam a } \\
\text { desigualdade social e } \\
\text { tecnológica, pois não } \\
\text { possuíam acesso facilitado a } \\
\text { rede internet. }\end{array}$ \\
\hline
\end{tabular}


começo do curso meu único meio de ter acesso à internet era aqui no polo.”

A questão da precarização da educação a distância é uma realidade. Os estudantes vivenciam situaçãoes de dificuldades no polo, atrapalhando o processo de ensino e aprendizagem. Por mais que essa modalidade educativa tenha o intuito de auxiliar o indivíduo, seu crescimento desordenado vem acompanhado de uma desestrutura. Por isso, tal crescimento deve ser observado de forma constante, pois, como lembra Belloni (2006, p.52) falando a respeito dessa expansão, "a EAD se apresenta como mais um modo regular de oferta de ensino, utilizada tanto no ensino superior quanto para a formação inicial ou continuada, cuja demanda tende a crescer exponencialmente".

A necessidade de expansão do número de vagas das universidades fez com que os gestores públicos criassem mecanismos para se abarcar um número cada vez maior de pessoas. Conforme já exposto, a ideia da criação do consórcio envolvendo a UAB incorporava a expansão e a formação de uma grande quantidade de alunos, a fim de se aumentar os índices de matriculas na educação superior (BRITO, 2013). Tal pretensão pode ser perigosa, pois a oferta de um ensino sem a estrutura adequada pode representar um erro e não um benefício à população. O sistema UAB não é eficaz sem a estrutura acadêmica das universidades federais, que oferecem profissionais capacitados e sem uma estrutura física necessária ao seu funcionamento.

Infraestrutura que dá suporte ao aluno, materiais adequados e sua plena utilização são essenciais para o atendimento ao estudante com qualidade. A questão do material impresso também tem sua relevância na educação a distância, pois o aluno precisa do acesso a livros, periódicos, monografias, teses e dissertações.

Dada essa realidade, investir, priorizar e efetivar verdadeiramente a educação a distância por meio de uma estrutura adequada, não apenas com bons professores, mas também com aparatos físicos de qualidade, se faz necessário para que o discente se desenvolva de maneira satisfatória. 


\subsection{Percepção sociopolítica do viver em Carinhanha}

Quando indagados sobre os sentimentos com relação à cidade onde viviam, Carinhanha, os estudantes declararam que gostavam muito do local, mas apresentaram também sentimento de revolta. A cidade apresenta muitas caracteríticas diretamente vinculadas à desigualdade e à degradação ambiental produzida pela má administrações dos políticos, segundo a visão de alguns estudantes. Outros já notam o crescimento e as mudanças históricas como algo positivo:

Sujeito 1: Eu gosto muito daqui, né... Mas, se pudesse, com certeza sairia.

Sujeito 2: Carinhanha...me sinto muito bem em morar aqui. A cidade mudou tudo com os anos. Hoje tem a UnB, tem a UNEB (...) os políticos de hoje estão muito melhor que antes.

Sujeito3: Aqui tinha que melhorar,oferecer mais estudos pra população... Tá pouco ainda as coisas.

Sujeito 4: Vi meu pai trocar voto por galinha. Cresci achando que era normal, mas fui vendo que não era certo. (...) Quis ser professor pra mudar isso um pouco, não é porque os professores que tive na cidade não me deram muita coisa boa que eu não vou querer ser bom. Aí que eu tenho que ser o melhor, pois vou trabalhar formando o futuro de Carinhanha.

Sujeito 6: Olha, se eu pudesse escolher morava em outro lugar, aqui não tem nada... mas tem minha família e eu penso neles.

A fala dos estudantes acentua uma característica que se faz presente quanto aos credenciamentos dos cursos à distância. Esse dado que surgiu na pesquisa vai de encontro aos estudos de Brito (2013), pois oferecer educação superior para os municipios é interessante e o gestor se promove positivamente com isso.

A cidade de Carinhanha - BA foi favorecida com essa modalidade educativa. É preciso, no entanto, ir além da democratização do acesso, observando a iniciativa sob um ponto de vista mais abrangente. 


\section{QUADRO 8: Percepção sociopolítica do viver em Carinhanha}

\section{Unidade temática: Cidade de Carinhanha sob a visão dos estudantes}

Vozes Representadas: estudantes de Carinhanha - BA Ped. - FE- UnB / UAB

\begin{tabular}{|c|c|c|}
\hline $\begin{array}{c}\text { Conteúdos verbalizados } \\
\text { Discurso Direto }\end{array}$ & Dis & $\begin{array}{l}\text { Análise Crítica: elementos } \\
\text { identificados nas vozes que } \\
\text { perpassam as questões } \\
\text { Geopolíticas }\end{array}$ \\
\hline $\begin{array}{l}\text { "Eu gosto muito daqui. } \\
\text { Carinhanha...me sinto muito } \\
\text { em morar aqui." } \\
\text { "Hoje tem a UnB, tem a } \\
\text { UNEB." } \\
\text { "Aqui tinha que melhorar, } \\
\text { oferecer mais estudos pra } \\
\text { população. Tá pouco ainda } \\
\text { as coisas.” } \\
\text { "Vi meu pai trocar voto por } \\
\text { por galinha. Cresci achando } \\
\text { que era normal, mas fui } \\
\text { vendo que não era certo.” } \\
\text { "Olha, se eu pudesse } \\
\text { escolher, morava em outro } \\
\text { lugar...” }\end{array}$ & $\begin{array}{l}\text { Gostam da cidade, há um } \\
\text { apego nas falas. } \\
\text { Reconhecimento da presença } \\
\text { das instituições de educação } \\
\text { superior como sendo positiva. } \\
\text { Necessidade de mais espaços } \\
\text { educativos para atender um } \\
\text { maior percentual da } \\
\text { população de Carinhanha. } \\
\text { Questões políticas que trazem } \\
\text { as mazelas da corrupção e de } \\
\text { pequenos acontecimentos } \\
\text { locais. } \\
\text { Não reconhecimento da } \\
\text { cidade como um local } \\
\text { atrativo e que oferece } \\
\text { oportunidades em diferentes } \\
\text { setores para o estudante. }\end{array}$ & $\begin{array}{l}\text { As questões sociopolíticas, } \\
\text { no que diz respeito às } \\
\text { oportunidades, } \\
\text { apresentam confusas nas } \\
\text { falas dos sujeitos. } \\
\text { Reconhecimento } \\
\text { Instituições de Educação } \\
\text { Superior naquela localidade. } \\
\text { Mas, apesar do prestígio, } \\
\text { ainda não há uma satisfação } \\
\text { com relação à quantidade de } \\
\text { vagas e de instituições. } \\
\text { A questão do coronelismo } \\
\text { político é apresentada na } \\
\text { compra (troca) do voto por } \\
\text { galinhas, segundo } \\
\text { entrevistado. }\end{array}$ \\
\hline
\end{tabular}

Gostar da cidade, confirmando um sentimento de pertencimento, contribue para a compreensão que o sujeito tem de si mesmo, já que é no lugar onde mora que o indivíduo estabelece as suas relações sociais e onde a sua herança cultural e familiar são adquiridas e desenvolvidas. Por isso, não perceber suas demandas sendo atendidas na cidade onde vive é desmotivador para o estudante. No que diz respeito aos estudos, ampliar as vagas na educação superior se faz necessário, mas sabemos que algumas cidades no interior do Brasil ainda 
necessitam ampliar a geração de empregos e a criação de oportunidades para oferecer uma melhor qualidade de vida para a população. Quando toda a dinâmica social, desde os setores básicos - como saúde, segurança, moradia, emprego, educação e até o lazer - está presente na cidade, os moradores são beneficiados e se sentem pertencentes ao lugar. É necessário, então, pensar a realidade em seus múltiplos aspectos e não somente em relação ao aspecto da formação acadêmica.

\subsection{Perspectiva de futuro}

Os estudantes de Carinhanha, que atualmente são egressos do curso de Pedagogia FE UnB / UAB, querem avançar em seus estudos, obtendo uma formação continuada. Em suas falas é ressaltada a vontade de alcançar patamares altos no que diz respeito ao aprofundamento acadêmico. Este dado surgiu nos questionários e também nas sete entrevistas narrativas realizadas.

Sujeito 1: Estudar é muito bom; acho bonito a pessoa estudada.

Sujeito 2 - Com certeza, por que não, né? Tem que tentar mesmo, quem sabe não dou aula em Salvador? Se eu continuar estudando, terei mais oportunidades.

\section{Sujeito 5 -Quero continuar estudando.}

Sujeito 6: Com certeza é assim que a gente vence, estudando.

Sujeito 7: Quero e preciso continuar estudando.

Dentre os 25 alunos que responderam ao questionário, 24 pretendem avançar em seus estudos com a realiazação de cursos e pós-graduações. O entusiasmo quanto a esse progresso é patente em suas falas. 


\section{Unidade temática: Perspectiva de futuro}

\section{Vozes Representadas: estudantes de Carinhanha - BA Ped. - FE- UnB / UAB}

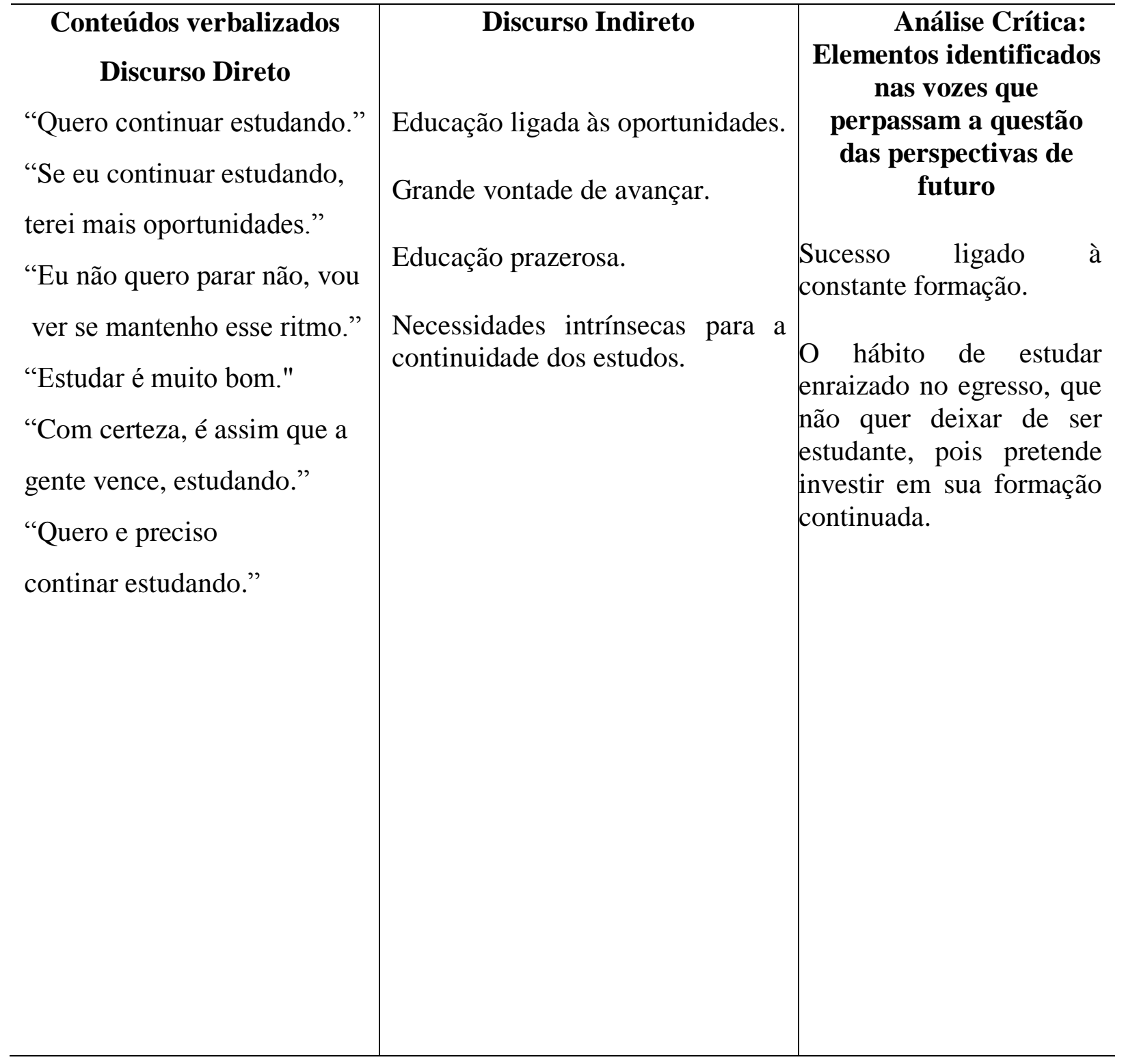

O pensamento desses egressos corrobora a necessidade de ampliação das ofertas de cursos do sistema educacional, incluindo a modalidade da EAD, especialmente no nível universitário e na pós-graduação.

Com a ampliação desse universo e o número crescente de alunos que entram na educação superior, a questão da longevidade escolar passa a ser um dos aspectos a serem observados no sistema educacional. Mobilizar maneiras e ações para fazer com que as 
camadas populares alcancem essa logenvidade se faz necessario. A questão da democratização do ensino de certa maneira amplia o acesso à educação, o que oportuniza a longevidade, conforme ressalta Nascimento (2009, p.27):

\begin{abstract}
O cenário de ampliação do ensino superior decorre diretamente da democratização das oportunidades de escolarização do nível fundamental e médio; bem como precede de programas governamentais e políticas de ação afirmativa que têm viablizado o prolongamento da escoloridade de setores populares.
\end{abstract}

Esse prolongamento, quando bem articulado, contribui positivamente para o sucesso escolar das camadas populares. O que tem sido benéfico e eficaz, mas, por detrás da longevidade, há fragilidades e questões ligadas à subjetividade dos sujeitos que irão interferir nessa dinâmica, sendo facilitadores ou dificultadores para esse prolongamento educacional. Sabemos que possuir um diploma tem o seu valor; no entanto, há de se observar também as questões sociais, conforme destaca La Mendola (2005, p. 66): "Possuir um diploma escolar de nível mais elevado é recurso útil para encontrar um emprego melhor, mas isso não elimina as desigualdades oriundas da origem social”.

As questões sociais estão imersas nessa realidade. No entanto, de acordo com as falas dos sujeitos, surge a questão do sucesso vir atrelado a inúmeras formações e acumulação de diplomas. Sabemos que o sujeito enfrentará diversas barreiras, como as econômicas, de classe, de genêro, dentre outras. Diante disso, a longevidade escolar não deve ser vista como definidora do sucesso. É importante reassaltar que esses fatores não são garantias, tampouco o passaporte para um futuro promissor. Não há como condicionar sucesso à acumulação de diploma. A principal função dos diversos níveis de formação deveria ser a da aquisição de cultura, com vistas ao desenvolvimento de um pensamento crítico. O sucesso é somente consequência de um processo prolongado e produto de uma gama de fatores sociopsicológicos que participam da formação da subjetividade do sujeito.

A busca pelo saber se materializa com cursos de graduação, extensão e pós-graduação e por meio de formação permanente. A questão da formação continuada é importante para o profissional que deseja desempenhar seu trabalho dentro dos parâmetros contemporâneos, tendo em mente que os saberes nunca se esgotam. 
5.13 Educação a distância e as questões de gênero

Questões de gênero também surgiram nas respostas dos formandos que são, em sua maioria, do sexo feminino e tiveram seu processo educacional perturbado por alguma situação difícil, cabendo uma transcrição mais detalhada dos dados presentes no questionário:

Acho que a maior dificuldade que tive foi com o meu marido, que achava que mulher não precisava estudar.

Eu não tinha com quem deixar meus filhos e isso me atrapalhava muito.

Meu marido era muito ciumento, não queria me deixar sair para os encontros no polo.

Para ele eu não podia sair de casa e para mim era muito importante estudar, o que me deixava triste.

Tais dados apareceram tanto no questionário como na entrevista narrativa e foram incorporados a esta pesquisa como um dos fatores que contribuem para o desempenho do estudante, para a visão que ele tem de si mesmo e para a longevidade escolar.

O público do curso é constituído em sua grande maioria por mulheres, e isso traz alguns estigmas quanto à questão da longevidade escolar e também do sentido que o diploma tem para essa mulher. A prática discursiva dessas mulheres é permeada por uma trajetória marcada por dificuldades e preconceitos. Tal realidade apareceu de modo bastante evidente na ocasião da entrevista narrativa, realizada na primeira ida a campo:

Sujeito 7: Quando eu casei sofri muito com o meu marido, até apanhar eu apanhei (...) Aí depois cansei e dei um basta. Ele falava que mulher não tinha que ter diploma. Hoje enxergo esse diploma como um empoderamento que eu conquistei sem ajuda de homem nenhum. E a minha vontade é continuar estudando, meu próximo passo é a pós-graduação.

Fica patente na fala do sujeito a questão de gênero, quando o seu companheiro prega um discurso dominante de que a mulher não necessita estudar, pois isso pode representar um futuro diferente do esperado pelos ideais machistas. Houve uma quebra desse discurso, pois a mulher conseguiu romper com essa trajetoria. 
De acordo com Resende e Ramalho (2013), há uma legitimação dentro dos discursos onde as relações de dominação são apresentadas como concretas, pois esse homem vivenciava uma estrutura social na qual a mulher não desempenhava um papel na sociedade. Esse homem utilizava até mesmo sua força física para impor relações de dominação frente à sua companheira.

Seguindo ainda os pressupostos de Resende e Ramalho (2013), pode-se observar a ocorrência da dissimulação, outro conceito importante na teoria do discurso, estando evidenciadda no fato de o homem achar normal e comum agredir sua mulher e impedir que ela avance em relação ao conhecimento.

O discurso dessa mulher é, portanto, permeado de subjetividade, mas que traduzem várias das questões sociais e culturais. Sua emancipação passa pelo empoderamento, e o empoderamento se torna possível com a continuidade dos estudos, sendo o conhecimento o fator determinante também para a mudança da situação original, na medida em que permitiu o despertar e o desenvolvimento da reflexão crítica.

Enxergar o diploma como algo que dá poder à mulher que sofre com a violência doméstica é esclarecedor e demonstra avanço, pois demonstra a negação da condição de vítima dessa mulher. O protagonismo assumido por ela faz com que se fortaleça diante das amarras culturais e dificuldades sociais. No caso da entrevistada, a opressão chegou ao extremo, culminando com a violência física, que vitimiza muitas mulheres no Brasil e que, segundo dados da Organização Pan Americana de Saúde ${ }^{13}$, atinge cerca de 17,26\% das mulheres brasileiras. Além da violência doméstica, muitas mulheres ainda sofrem algum tipo de violência nos diferentes locais que ocupa.

Para Lisboa (2008, p. 2), é necessária, então, a promoção do empoderamento das mulheres, e isso deve partir do reconhecimento de que a discriminação de gênero existe:

Os estudos feministas partem do pressuposto que o empoderamento das mulheres é condição para a equidade de gênero. O primeiro passo para o empoderamento deve ser o despertar da consciência por parte das mulheres em relação à discriminação de gênero: reconhecer que existe desigualdade entre homens e mulheres, indignar-se com esta situação e querer transformála.

\footnotetext{
${ }^{13}$ Disponível em: <http://www.paho.org/bra/index.php?option=com_content\&view=article\&id=3165:diainternacional-da-mulher\&catid=940:bra-04-b-noticias\&Itemid=498>. Acesso em: jun. de 2013.
} 
No caso da referida resposta, se pode notar que houve uma indignação, que deu origem à libertação, referida pela entrevistada como um "basta" na situação. O diploma veio como um prêmio, um troféu que ela conquistou por esforços próprios e que vinculou à própria capacidade e dedicação, reiterando que conquistou o diploma sem "ajuda de homem nenhum".

O fato de a mulher ocupar espaços que antes lhes eram negados, por diversos fatores, é um dos aspectos que aparecem nos trabalhos sobre a modalidade da EAD e seu grande contingente de estudantes adultos do sexo feminino. Mas outras pesquisas devem ser feitas nesse campo para que se possa promover cada vez mais o empoderamento dessas mulheres e a consequente modificação de sua condição social e cultural.

5.14 Sentido e significado que o egresso dá ao curso de pedagogia e ao diploma da Universidade de Brasília

No que concerne ao "sentido esignificado que o egresso dá ao curso de Pedagogia e ao diploma oferecido pela Universidade de Brasília”, para os discentes que responderam sobre os fatores que o levaram a realizar o curso de pedagogia da UnB, as respostas se apresentaram da seguinte maneira no questionário:

Seis sujeitos colocaram a UnB como única oportunidade de ingressar no nível superior; um sujeito expôs a necessidade de se inserir no mercado de trabalho, sendo para isso necessário cursar uma universidade; outro respondente expôs a necessidade de se capacitar por meio da graduação; dois alunos colocaram que não havia faculdade em Carinhanha, por isso estavam fazendo um curso a distância; e oito formandos explicaram que se tratava de uma realização pessoal, ver alcançado o sonho de ter um diploma e ser formado.

As respostas dos sujeitos apontaram para o grande valor que eles deram quanto a oportunidade de cursar uma graduação na cidade de Carinhanha, colocando a UnB como única oportunidade para eles. Em contrapartida a UNEB e UESB se fazem presentes no polo, oferecendo cursos de graduação e especialização. Há um capital simbólico forte - dado ao prestígio e peso que a Universidade de Brasília tem por parte desses formandos que não visualizam outra instituição além da UnB como sendo uma única oportunidade detentora de grande poder simbólico. Bourdieu (1989 pág. 61) traz a questão do reconhecimento do poder simbólico exercido: "O poder simbólico é um poder que está em condições de se fazer reconhecer, de se obter reconhecimento". 
A questão da importância do diploma também surgiu com força na fala dos estudantes:

Sujeito 1-Antigamente qual era a chance da mulher fazer outra coisa aqui a não ser virar dona de casa? Esse curso me fez acreditar que eu posso muito mais do que ser professora do município. Não que ser professora do município é ruim, é bom, me orgulho disso, mas eu quero mais, né?... E esse curso me fez acreditar que eu posso.

Sujeito 3: Nossa, esse diploma pra mim é tudo... Tenho muito orgulho das minhas raízes. Sou baiana, nordestina, sim, e diplomada! Vim da roça e sou da roça, para mim é um progresso e agradeço a Deus pela oportunidade. Não precisei ir para Salvador para conseguir isso. Quando eu era mais nova eu ficava preocupada: Será que eu vou conseguir vencer, estudar? Não via esperança para mim aqui de ser alguém, de ter oportunidades. E elas surgiram e eu agarrei com unhas e dentes (...) esse diploma é minha vida.

Sujeito 5 - O curso foi ótimo e já tô com saudades. Para mim foi tudo perfeito: Tutores, professores. Teve problema sabe, mas de estrutura... Foi muito bom e importante para a minha vida. 
QUADRO 10- Sentido e significado que o egresso dá ao curso de Pedagogia e ao diploma da Universidade de Brasília

\section{Unidade temática: vozes representadas: estudantes de Carinhanha - BA Ped. - FE -} UnB / UAB

\begin{tabular}{|c|c|c|}
\hline $\begin{array}{l}\text { Conteúdos verbalizados } \\
\text { Discurso Direto } \\
\text { “Nossa, esse diploma pra mim } \\
\text { é tudo... Tenho muito orgulho } \\
\text { das minhas raízes. Sou baiana, } \\
\text { nordestina, sim, e diplomada! } \\
\text { Vim da roça e sou da roça, } \\
\text { para mim é um progresso e } \\
\text { agradeço a Deus pela } \\
\text { oportunidade. Não precisei ir } \\
\text { para Salvador para conseguir } \\
\text { isso. Quando eu era mais } \\
\text { nova, eu ficava preocupada: } \\
\text { Será que eu vou conseguir } \\
\text { vencer, estudar? Não via } \\
\text { esperança para mim aqui } \\
\text { de ser alguém, de ter } \\
\text { oportunidades. E elas } \\
\text { surgiram e eu agarrei com } \\
\text { unhas e dentes (...) esse } \\
\text { diploma é minha vida.” } \\
\text { “O curso foi ótimo e já tô } \\
\text { com saudades. Para mim foi } \\
\text { tudo perfeito: tutores, } \\
\text { professores... Teve problema, } \\
\text { mas de estrutura... Foi muito } \\
\text { bom e importante para a } \\
\text { minha vida.” }\end{array}$ & $\begin{array}{l}\text { Discurso Indireto } \\
\text { Orgulho do diploma, pois, } \\
\text { apesar das raízes humildes, } \\
\text { houve um rompimento com o } \\
\text { estigma da falta de } \\
\text { oportunidades. } \\
\text { Novas perspectivas e uma } \\
\text { visualização de um futuro } \\
\text { mais promissor quanto ao } \\
\text { acesso ao mercado de } \\
\text { trabalho. } \\
\text { curso visto sob uma ótica } \\
\text { altamente positiva, declarado } \\
\text { pelo estudante que o definiu } \\
\text { como "perfeito", apesar dos } \\
\text { problemas de infraestrutura. }\end{array}$ & $\begin{array}{l}\text { Análise Crítica: } \\
\text { Elementos identificados nas } \\
\text { vozes que perpassam o } \\
\text { curso de Pedagogia e o } \\
\text { diploma } \\
\text { O diploma visto como fator } \\
\text { propulsor do sucesso; } \\
\text { O curso também visualizado } \\
\text { como a chave para um futuro } \\
\text { profissional promissor. } \\
\text { Equipe de professores e } \\
\text { tutores exaltados pelos } \\
\text { estudantes com uma visão } \\
\text { extremamente positiva, } \\
\text { profissionais apontados como } \\
\text { "perfeitos". } \\
\text { O curso superior visto com } \\
\text { importante para a vida, algo } \\
\text { essencial na visão do } \\
\text { estudante que não identifica } \\
\text { outra ideia de oportunidade } \\
\text { para acesso a mercado de } \\
\text { trabalho. }\end{array}$ \\
\hline
\end{tabular}




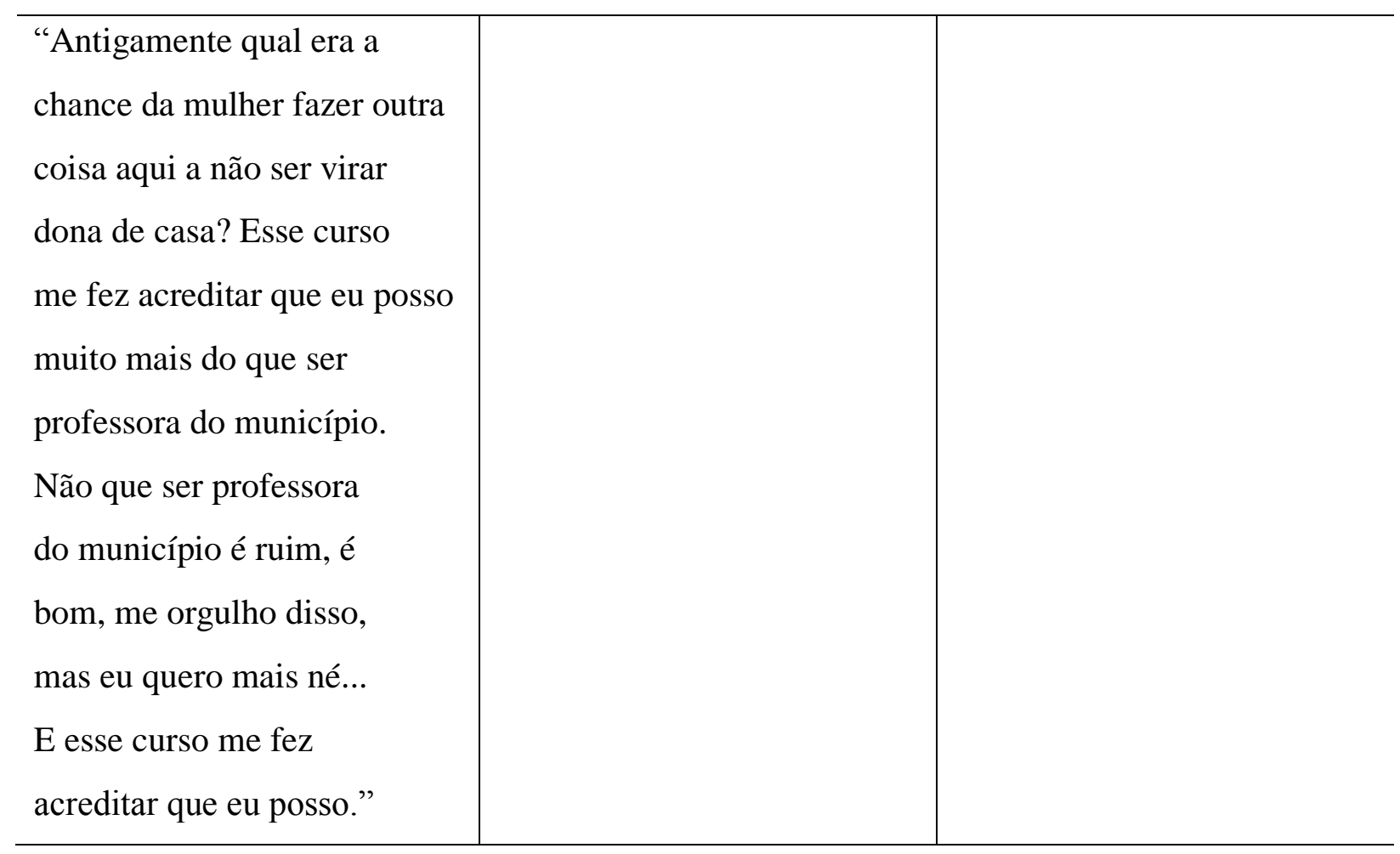

A ideia do diploma como sendo a salvação e exercendo esse poder nos alunos é interessante de se observar. Setton $(2005$, p.80) discute como os diplomas representam um capital cultural e aponta:

Para o desenvolvimento desta reflexão, seria importante alertar, no entanto, que o capital cultural como recurso estratégico pode ser cultuado de várias formas. Ou seja, é preciso salientar que a posse desse novo capital pode derivar de investimentos culturais diversos. Pode se expressar na forma de diplomas, na visitação a museus e assistência a concertos eruditos ou, na sua impossibilidade, pode se expressar em comportamentos menos aristocráticos não deixando de ser utilizado como capital distintivo.

O capital cultural, segundo Bourdieu (1979, p. 82), pode existir em diferentes formas:

No estado incorporado, ou seja, sob a forma de disposições duráveis do organismo; no estado objetivado, sob a forma de bens culturais - quadros, livros, dicionários, instrumentos, máquinas, que constituem indícios ou a realização de teorias ou de críticas dessas teorias, de problemáticas, etc.; enfim, no estado institucionalizado, forma de objetivação que é preciso colocar à parte porque, como se observa em relação ao certificado escolar, ela confere ao capital cultural - de que é, supostamente, a garantia propriedades inteiramente originais.

Logo, a busca pelo capital cultural escolar se mantém e é perseguida como uma das vias para se obter uma posição social superior e também de se vislumbrar perspectivas diferentes, antes percebidas como inalcançáveis e distantes de sua realidade. 
Nas respostas dos discentes, surgiram também a questão da capacitação profissional e da inserção no mercado de trabalho a partir da universidade, vista, nesse caso, como tendo uma função profissionalizante, pois permite o acesso a oportunidades no mercado de trabalho e ascenção social a partir da capacitação técnica.

Alguns dos egressos de Carinhanha se sentiram privilegiados, afirmando, algumas vezes de forma veemente, que, mesmo em face dos diversos problemas enfrentados, foram capazes de romper com paradigmas e exaltaram a nova condição de nordestino diplomado. Nota-se também uma valorização exarcebada quanto à obtenção do diploma. E isso se deve ao fato de o sujeito ter vivenciado situações que o fizeram acreditar que ele não romperia com o estigma da falta de oportunidade. Isso porque a falta de acesso à educação de nível superior assombra não apenas a região do nordeste brasileiro, mas, também, outras regiões, reforçando a ideia de que não é fácil romper as desigualdades regionais e sociais.

O diploma tem um valor social bastante marcado para as pessoas entrevistadas. O capital cultural adquirido por esse instrumento eleva, segundo sua visão, o status de quem o obtém. Como se sabe, porém, o diploma, por mais que coloque o sujeito em um patamar dito elevado na esfera social, ele não tem o poder de acabar instantaneamente com a desigualdade, que tem raízes históricas e políticas mais profundas, nem pode interferir de modo definitivo na divisão da sociedade em classes, segundo se observa no sistema capitalista.

Apesar disso, no Brasil, a universalização do acesso ao ensino básico provocou uma mudança no cenário, conforme aponta pesquisa do IPEA (2011, pág. 21):

Em 1995, 15,5\% da população com 15 anos ou mais de idade não sabia ler nem escrever; este percentual caiu para 9,7\% em 2009. No entanto, neste mesmo ano, encontram-se, na região Nordeste, $20,5 \%$ de negros em situação de analfabetismo, contra $14,2 \%$ dos brancos. Na área rural nordestina, identifica-se que 32,6\% das pessoas não tiveram acesso à educação formal. Observa-se que a média de anos de estudos da população com 15 anos ou mais de idade aumentou de 5,5 anos, em 1995, para 7,5 anos, em 2009, representando um aumento de 2 anos no período. Considerando-se a população negra, identifica-se um aumento de 2,4 anos no mesmo intervalo, o que não representa ainda o rompimento das desigualdades: em 2009, os/as negros/as tinham 6,7 anos de estudos, contra 8,4 anos da população branca.

Dados de 2009 trazem uma melhora dessa realidade, provando que o país evoluiu quanto à democratização do ensino. No entanto, ainda temos um longo caminho, dada a grande quantidade de pessoas fora da escola e fora da universidade e as outras demandas sociais que se refletem no desempenho daqueles que conseguem ingressar no sistema educacional. 
Em termos governamentais, é necessário pensar em recursos e oportunidades tanto para o estudante quanto para a cidade em que ele vive, a fim de que haja o aproveitamento adequado de tais recursos empregados na educação.Para isso, é preciso estar atento à necessidade de redução das desigualdades entre os diferentes estados da federação. Dados do IPEA (2011, p. 21) comprovam a relação entre o acesso a educação colabora para a dimunuição dedesigualdades (as raciais, por exemplo):

\begin{abstract}
Em 1995, a taxa de escolarização líquida no ensino superior- que mede a proporção de pessoas matriculadas no nível de ensino adequado para sua idade - era de $5,8 \%$, chegando, em 2009 , a $14,4 \%$. Neste mesmo ano, esta taxa era de $21,3 \%$ entre a população branca, contra apenas $8,3 \%$ entre a população negra, chegando a apenas 6,9\% entre os homens negros. Em 2009, a taxa de escolarização das mulheres no ensino superior era de $16,6 \%$, enquanto a dos homens, de $12,2 \%$. A taxa de escolarização de mulheres brancas no ensino superior é de $23,8 \%$, enquanto, entre as mulheres negras, esta taxa é de apenas $9,9 \%$. As políticas de expansão das universidades, o Prouni, as ações afirmativas e outras políticas têm contribuído para os avanços nesta área. No entanto, as desigualdades raciais que determinam e limitam as trajetórias de jovens negros explicam a discrepância dos dados.
\end{abstract}

O jovem negro ainda tem um limitador socioeconômico que o diferencia do jovem branco, que encontra mais facilidade para ascender socialmente. Isso fica ainda mais dramático se lembramos que a população brasileira (IPEA 2011, p. 3) é de maioria negra: "No Censo Demográfico de 2010, 97 milhões de pessoas se declararam negras, ou seja, pretas ou pardas, e 91 milhões de pessoas, brancas". E a pesquisa realizada em Carinhanha também apresenta a maioria de egressos do curso como sendo negra. As políticas afirmativas que favorecem os negros e também as políticas de expansão das universidades têm sido eficazes, ainda que insufucientes, no atendimento a essas minorias.

A importância do curso para esses sujeitos foi significativa e trouxe influências consideradas positivas para a sua vida pessoal. A educação a distância não vem com o intuito de ser salvacionista ou para suprimir o ensino presencial. Essa modalidade vem para contribuir para a melhoria do cenário educacional brasileiro.

Sujeito 1: Nossa... Dizer o que o curso significa me dá até vontade de chorar. Assim, através dele eu posso sonhar com uma coisa melhor pra mim (choro). Eu e minha família sabemos o que ele significa, não tenho palavras.

Cabe ressaltar que atender às minorias tem esse efeito positivo do ponto de vista dos índices de desenvolvimento sociais mais gerais e traz consigo também uma carga emocional muito forte, revelando um significado pessoal muito marcado para o egresso. Este agora passa 
a se ver como aquele que foi capaz de finalizar uma etapa importante do seu processo educacional a despeito de todas as dificuldades e dos estigmas de classe, gênero e raça.

A educação a distância propicia oportunidades e contribui com a expansão da oferta do ensino superior em comunidades pobres do interior do país. Possibilitar a essas comunidades o acesso à educação de nível superior é um passo fundamental para se obter uma real democratização do ensino.

\subsection{Recontextualização das vozes dos Sujeitos}

A fim de formar uma ponte entre os principais pontos destacados, juntando as vozes dos autores, as dos sujeitos e também a voz da pesquisadora, cabe aqui nessa parte do texto um momento refelexivo e integrador.

Para Resende e Ramalho (2013, p. 101), é preciso salientar, “a seleção das vozes nessa recontextualização, bem como as maneiras como elas são representadas dizem muito sobre o seu posicionamento político desse evento discursivo na rede de práticas sociais". O registro dessas vozes, portanto, deve responder aos objetivos do trabalho e envolver o entendimento e os ideais da pesquisadora.

O objetivo geral do trabalho teve como foco analisar as trajetórias de estudantes do curso de Pedagogia - FE-UnB/UAB2, considerando as suas condições de vida no lugar e as perspectivas de longevidade escolar no contexto da realidade social no Município de Carinhanha - Bahia.

No decorrer da pesquisa e a partir do que foi aparecendo nas narrativas e falas dos sujeitos envolvidos, outros aspectos específicos foram sendo estudados e articulados entre si.

Com o objetivo de aprofundarmos mais ainda essa discussão, a recontextualização aparece como uma forma de se trabalhar de maneira mais integrada alguns dos aspectos estudados.

A respeito das trajetórias dos sujeitos, é preciso observar a seguinte realidade: eles enfrentam uma jornada de trabalho dura, pois assumem inúmeras reponsabilidades (desde as familiares, financeiras e sociais), complementando a renda com empregos diversos. A realidade subjetiva retrata o esforço desprendido para vencer essas dificuldades e apresentaa luta dos sujeitos contra os estigmas e preconceitos de classe, de gênero, de raça e de região geográfica do país. 
O acesso e permanência desses sujeitos no sistema educacional, portanto, não depende apenas de seus esforços ou unicamente deles. As estruturas sociais, culturais e econômicas as quais perpassam essas relações são decisivas para o desempenho e a permanência desses sujeitos nos cursos da EAD. Nesse sentido, chama a atenção a importância de fatores motivadores como afeto, atenção e compromisso no acompanhamento desses estudantes por parte dos professores e tutores. O ensino foi ressaltado pelos discentes como de qualidade,não somente por causa da competência acadêmica dos profissionais envolvidos, mas também por sua disposição em acolher e incentivar os estudantes no processo de aprendizagem.

No que diz respeito às condições do município de Carinhanha - BA (que também são fatores importantes e intrísecos aos sujeitos), há de se observar que as questões culturais, políticas e socioeconômicas atuaram como dificuldades. Além disso, desde a educação básica, os alunos tiveram algumas deficiências educacionais. Essas deficiências foram outro fator desestabilizador para os estudantes no momento em que ingressaram no ensino superior. Quando se tornaram alunos da Universidade de Brasília, se depararam com uma realidade distante, um bem cultural totalmente desconhecido e um mundo de novas palavras e conceitos. Esses estudantes tiveram que assimilar um vocabulário novo para eles e novas formas discursivas, muitas vezes sem as ferramentas de aprendizagem que se supunha deveriam dominar antes do ingresso naquele nível de ensino.

A evasão ou insucesso na graduação universitária não está, portanto, diretamente relacionada diretamente à vontade dos sujeitos. Nesse sentido, cabe perguntar: Será que nossa educação básica - que se divide em ensino fundamental e médio - tem preparado verdeiramente os alunos para o ensino da educação superior? Respostas a essa pergunta foram dadas pelos próprios sujeitos da pesquisa quando relataram não estar prontos e a série de dificuldades que tiveram durante o curso. Os índices dos sistemas de avaliações nacionais trazidos no corpo do trabalho demonstram a fragilidade do sistema, que necessita de novas reformulações e também de um despertar paras as condições da qualidade do ensino público.

Ainda discutindo as condições de vida naquela localidade, a questão da desigualdade aparece de forma objetiva e subjetiva. Objetiva no que diz respeito à própria realidade a qual o sujeito vivencia conforme ressaltado e a subjetiva no diz respeito à leitura social e política que o sujeito faz em relação a essa dinâmica. 
Ainda que apresentassem argumentos e narrativas que poderiam levar a um entendimento mais amplo da questão, os sujeitos pesquisados em momento algum demonstraram compreender a verdadeira dimensão da estrutura opressora do sistema sociopolítico que os envolve, fazendo alusão, por exemplo, à divisão da sociedade em classes sociais e a ausência de políticas que possibilitem a equidade nas ofertas de oportunidades, como elementos da estrutura social e que está na base de suas dificuldades acadêmicas. A divisão da população em classes e a ausência de políticas que possibilitem a equidade nas ofertas de oportunidades, além da notória gestão ineficiente e negligente do dinheiro público, são alguns dos elementos definidores e mantenedores dessa estrutura social.

Segundo Brito (2013) a expansão da EAD ainda não é suficiente para a diminuição dessas desigualdades. Não adianta enxergarmos a educação a distância como a redentora, pois ela possui falhas, foi gerada em meio a dificuldades e os municípios que aderiram ainda não internalizaram completamente a proposta.

A respeito da perspectiva de longevidade escolar há de se pensar no que ela significa no contexto em esses indivíduos estão inseridos, levando-se em conta os aspectos objetivos e subjetivos da questão. Objetivamente, quando o sujeito pensa na obtenção do diploma como forma de garantir um futuro melhor e perspectivas diferentes das que ele vivencia. E, subjetivamente, no que esse diploma representa: um objetovalioso capaz de transformar sua vida, sendo cultuado de forma veemente. Na mesma direção, a Universidade de Brasília é vista por esses estudantescomo uma instituição de prestígio, sendo supervalorizada por eles, o que contribui para a percepção do diploma como um objeto de culto.

A respeito da perspectiva de longevidade escolar, cabem ainda alguns comentários. $\mathrm{O}$ sucesso não depende exclusivamente do discente ou da quantidade de diplomas ou até mesmo do quanto ele investir. O sucesso é um conceito amplo que não pode ser definido de maneira simplista. No caso desses egressos a longevidade escolar aconteceu, pois eles alcançaram o êxito de se formar e esse mesmo êxito é visto como algo positivo, um sucesso. Mas não há só o caminho do curso universitário. Outros existem. O diploma universitário, ainda que uma meta a ser alcançada por muitos e uma das principais no que diz respeito aos estudantes pesquisados, não deve ser vista como a única possibilidade de sucesso na vida dessas pessoas. Cabe à escola redefinir o conceito de sucesso escolar, identificando-o à obtenção de resultados voltados para o conhecimento e não para a titulação, devendo esta ser vista como 
consequência do êxito dos estudantes em relação aos estudos e não o objetivo único a ser alcançado.

Sobre a questão de genêro é importante ressaltar que os sujeitos que participaram da pesquisa eram, em sua maioria, mulheres. Não se deve ignorar esse dado, pois, como se sabe, as condições sociais ainda não são igualitárias entre homens e mulheres. Por isso, oferecer para essas mulheres oportunidade de estudo e acesso ao mercado de trabalho deve ser um compromisso dos responsáveis pelas políticas públicas voltadas para a educação. Por meio de um ensino comprometido com a emancipação da mulher e eficiente no combate às desigualdades de gênero, a mulher ganha espaço, voz e oportunidade de modificar a sua realidade.

Além das reflexões aqui apresentadas, há espaço para outras discussões e o momento de recontextualizar o texto pressupõe um olhar mas próximo da pesquisadora partindo do entendimento de que novos olhares podem trazer novas reflexões. 


\section{O DIPLOMA COMO EMPODERAMENTO}

A questão de gênero surgiu em vários momentos da pesquisa. Dada essa realidade, desconsiderá-la denotaria uma falta de compromisso social frente à situação a qual os egressos pertenciam. Além disso, não seria possível ignorar os dados que surgiram e que exigiram um aporte teórico suplementar dentro da pesquisa.

A questão do diploma é vista hoje como uma necessidade do indivíduo que necessita se profissionalizar, uma porta de acesso viável ao mercado de trabalho. No caso das mulheres, o diploma significa, além disso, um empoderamento diante das condições adversas. Friedmann (1996, p. 8) define o empoderamento como "todo acréscimo de poder que, induzido ou conquistado, permite aos indivíduos ou unidades familiares aumentarem a eficácia do seu exercício de cidadania".

O empoderamento também pode ocorrer por meio de políticas públicas que promovam a equidade entre a população, de maneira que se conquistem espaços sociais antes negados ou não ocupados por pessoas que foram excluídas e tiveram seus direitos tolhidos, seja devido a aspectos sociais, financeiros ou de gênero.

A UAB deve ser pensada, portanto, como uma política pública que oferece a essas populações o acesso à educação superior, diminuindo as desigualdades tão latentes no Brasil. Isso amplia o significado e a importância dessa modalidade de acesso à educação, resgatando seu papel social e sua necessidade histórica.

O ingresso no ensino superior faz com que a mulher consiga atingir patamares sociais mais altos, o que promove o seu empoderamento. Desse modo, ela tem um elemento importantíssimo para lhe auxiliar a romper com a pobreza, a violência e a falta de perspectivas. Segundo Lisboa (2007, pág. 4),

\footnotetext{
As mulheres pobres são excluídas dos direitos mínimos porque suas famílias não tiveram ou não têm acesso ao poder social para melhorar as condições de vida de seus membros; elas não têm acesso ao poder político porque não compartilham as tomadas de decisões; não possuem o poder da voz, nem o da ação coletiva.
}

Dar voz a essas mulheres que foram silenciadas pela pobreza e pela falta de oportunidades deve ser também a preocupação das políticas públicas, no sentido de dar continuidade aos avanços obtidos pelos movimentos sociais voltados para o atendimento à mulher e a outras minorias. A revolução feminina, que visou dar voz à mulher, de acordo com Cheron e Epping (2009, pág. 3), tem uma longa história e pode, assim, ser caracterizada: 
No mundo ocidental, a revolução feminista, que tem incremento a partir dos anos 1960, modifica - embora lentamente - conceitos, valores e paradigmas e impulsiona a tomada de consciência do papel da mulher para além dos de filha, esposa e mãe. O nível de instrução cresce, ampliam-se as funções desempenhadas por mulheres, aumenta o número de mulheres atuantes na força de trabalho. Paulatinamente, as próprias mulheres se reconhecem como agentes da vida social, econômica e política.

Políticas públicas como a UAB, voltadas para a educação e para projetos de longo prazo, criam melhores perspectivas para essas mulheres, são relevantes e mais eficazes do que políticas assistencialistas emergenciais. Cheron e Epping (2009, pág. 12) ressaltam a necessidade de políticas públicas que incentivem o desenvolvimento pessoal:

As políticas de sobrevivência para mulheres pobres e sua prole não são suficientes para modificar a realidade. O empoderamento das mulheres, entretanto, modifica a percepção que a mulher tem de si e do mundo, trabalha sua auto-estima e visa a capacitá-la para competir igualitariamente no mercado de trabalho e nas outras esferas de participação: social, política, cultural. Políticas assistencialistas, como renda mínima e auxílio alimentar, deixam de incentivar a independência da mulher, sem a qual não se podem vislumbrar mudanças significativas na realidade.

Para se obter mudanças é preciso investir, criar e estimular ao máximo a capacitação das mulheres. O genuíno empoderamento traz mudanças sociais e o caminho está em se investir em efetivas políticas públicas que possam dar vazão à educação e à difusão do conhecimento.

No entanto, o diploma, sozinho, não significa a libertação total, tampouco a plena igualdade. Segundo estudos de Beltrão e Alves (2004), o aumento da escolaridade das mulheres não reflete conquistas iguais no mercado de trabalho, e as mulheres recebem salários inferiores aos homens da mesma condição.

Essas questões necessitam ser respondidas. Até que ponto a política pública consegue resolver o emaranhado de fatores sociais, conceitos e subterfúgios presentes nas relações sociais? A luta por condições iguais não se esgota em políticas públicas, mas deve partir de reflexões e mudanças de atitudes que influenciem a sociedade alterando seu modo de agir como, por exemplo, o estereótipo de ser frágil e inferior que a mulher ainda carrega, no imaginário popular, em relação ao homem.

No entanto, há de se buscar ainda uma igualdade quanto a esses aspectos, cabendo refletirmos se há um número significativo de mulheres galgando o ensino superior e que medidas podem ser tomadas quanto a essas questões. Segundo estudos de Madsen (2008, p.101), a representação de mulheres em instituições públicas de ensino superior ainda é insuficiente, sendo os homens a maioria: 
Se pensarmos na dimensão da representação política dentro dessa estrutura, concluiremos facilmente que há forte desequilíbrio entre homens e mulheres nos espaços de formulação da educação brasileira. Este, na verdade, não é um quadro muito diferente daquele das demais instituições públicas brasileiras. No entanto, não deixa de chamar a atenção que justamente o campo da educação - tido historicamente como um campo feminino por excelência apresente um quadro de disparidades tão marcantes.

As diferenças ainda existem e não temos um número significativo de professores universitários e reitores do sexo feminino. Dessa forma, esses espaços ainda têm sido ocupados em sua maioria por homens e nem sempre o diploma tem chegado à mão das mulheres de maneira igualitária, cabendo-nos refletir até que ponto a educação tem se efetivado.

Essas e outras questões, ligadas ao acesso não apenas à educação, mas também a outros espaços sociais onde a mulher tem dificuldade de transitar, devem ser plenamente discutidas. Piovesan (2011, pág. 83) apresenta a situação do Brasil em relação a outros países.

O Brasil situa-se no $81^{\circ}$ lugar no ranking que mede o alcance da desigualdade entre homens e mulheres em 134 países do mundo, tendo como indicadores o acesso à educação, à saúde, a participação econômica e política das mulheres, de acordo com o relatório Global Gender Gap (2010). O estudo avalia a forma pela qual, em um mesmo país, homens e mulheres exercem seus direitos políticos, sociais e econômicos. Conclui que nenhum país do mundo trata de forma absolutamente igualitária homens e mulheres. (...) Se comparada com outros países latino-americanos, como a Argentina (24 ${ }^{\circ}$ lugar) e Peru ( $44^{\circ}$ lugar), é preocupante a performance brasileira, explicada, sobretudo, pela reduzida participação política de mulheres.

Nenhum país do mundo segundo Piovesan (2011) trata de forma igualitária homens e mulheres. As diferenças têm sido visíveis e reais em diversos aspectos, incluindo o acesso à educação, que segundo Piovesan (2011), o Brasil é o país da América Latina que fica em posição inferior no que diz respeito ao acesso das mulheres à educação, perdendo para Argentina e Chile. Mesmo exercendo em alguns casos funções iguais às dos homens, as mulheres recebem em média 30\% a menos do que eles (PIOVESAN, 2011).

A falta de tempo para se dedicar aos estudos também tem sido o empecilho de algumas mulheres para transitar nos espaços educacionais, devido aos afazeres domésticos, tarefa atribuída em grande parte ainda às mulheres de modo geral, segundo Pastore (2007, pág. 1):

Além das diferenças de renda, as mulheres enfrentam uma situação desfavorável na divisão das tarefas domésticas. Os maridos brasileiros dedicam, em média, apenas 0,7 hora de seu dia ao trabalho do lar. As mulheres que trabalham fora põem 4 horas diárias. 
A mulher sofre ainda quanto a esta realidade, pois possui incontáveis afazeres e também um acúmulo de tarefas muito grande, tendo diversos papéis sociais que podem, sim, servir de impeditivos no que concerne à dedicação ao estudo. Além desses fatores de ordem social, a mulher por vezes vivencia situações de violência e também de desigualdades sócioeconômicas que contribuem para sua baixa qualificação acadêmica.

A proposição e o desenvolvimento de ações concretas que auxiliem a mulher no processo de inserção na sociedade de maneira justa deve ser uma das tarefas da educação, de modo que essa mulher consiga transitar em várias instâncias sociais como a instituição educacional e o mercado de trabalho. Buscar a igualdade e o rompimento dos velhos paradigmas que põem sempre a mulher em posição inferior a do homem deve ser uma constante. A educação tem um importante papel nesse processo, pois altera de algum modo, o imaginário popular e se integra a outras conquistas no caminho do empoderamento feminino, em seus aspectos econômicos, sociais e culturais. 


\section{CONSIDERAÇÕES FINAIS}

Este trabalho teve como objetivo analisar as trajetórias de estudantes do curso de Pedagogia - FE-UnB/UAB2, considerando as suas condições de vida no lugar e as perspectivas de longevidade escolar no contexto da realidade social no Município de Carinhanha - Bahia. Foi verificado também a importância dada aos egressos em relação ao diploma adquirido. Também foi analisada a concepção que o egresso possui a respeito da educação a distância oferecida pela Universidade de Brasília e a questão das trajetórias de cada um, ressaltando-se os fatores que favoreceram e foram dificultadores para a conclusão do curso na modalidade a distância.

Quanto aos problemas ligados às condições de vida daquela localidade, os dados mostram que os sujeitos tiveram uma trajetória difícil, enfrentando muitos problemas, muitos deles derivados de sua condição socioeconômica. É ressaltado também que o município de Carinhanha não propicia muitas oportunidades para que esse aluno curse um nível superior, e a educação a distância é a única porta de acesso universitário para esse sujeito - cabendo repensar se ela realmente tem sido suficiente para atender à demanda da cidade. A questão das políticas sociais serem insuficientes também foi uma realidade presente na pesquisa.

Outro ponto que também é necessário destacarmos diz respeito ao fato de que o consórcio UAB ainda não tem conseguido cumprir com o seu papel de tornar a educação crítica e verdadeiramente emancipadora. Na pesquisa, foi constatado que os sujeitos participantes não identificaram uma estrutura opressora por detrás de todo o sistema sociopolítico no qual eles se encontram. Tampouco foi observado pelos estudantes que a propagada, mas, em muitos aspectos, pretensa democratizacão do ensino tem como objetivo, muitas vezes, apenas se obter índices e números. Conforme ressalta Schneider (2013, p. 213):

\footnotetext{
Verificou-se uma política para manter alunos e educadores em um sistema que utiliza a educação como controle, que aumenta índices estáticos em prol de um discurso que democratiza; e ainda percebeu-se que estão submersos em uma ideologia que defende interesses universais, mas, na prática permanecem no sistema particular.
} 
A manutenção do sistema ideológico, identificada na formação que tem como finalidade a obtenção de índices de ordem publicitária e não uma emancipação crítica e real da sociedade faz com que o verdadeiro significado do ensino e a própria democratização tão buscada fiquem submersos e não realizados, ou apenas alcançados parcialmente. Por outro lado, uma educação que leve o sujeito a pensar e problematizar sua própria condição social deve se colocar ela mesma entre os elementos a serem levados em consideração, ou seja, é preciso entender os alcances da EAD a partir do estudo de seus objetivos, da sua qualidade e de seus efeitos enquanto modalidade de ensino.

No que diz respeito ao diploma e qual o sentido ele tem para esse egresso, a maioria dos discentes colocou que o mesmo representa um reconhecimento e uma conquista pessoal, e enxergam com orgulho o diploma que irão adquirir, sendo enfáticos quanto a isto. Alguns associam a conquista de seu diploma à religião, e são enfáticos no agradecimento a Deus pela conquista. Em todos, fica evidente a alegria em relação à conquista e a esperança em relação ao futuro.

A educação a distância naquela localidade representou um benefício para a população. Apesar dos problemas de infraestrutura, como foi ressaltado pelos próprios egressos, ela foi exaltada e a equipe de professores e tutores foi vista com positividade e prestígio, alcançando um nível de satisfação alto perante os estudantes.

Esses egressos enfrentaram dificuldades para estudar na modalidade a distância, desde a falta de manejo com o computador até mesmo com a pouca familiaridade com a escrita acadêmica. A falta do hábito de estudar também foi um elemento dificultador no desempenho dos estudantes. No entanto, com um acompanhamento eficaz da equipe docente e também com esforços próprios e superação dessa realidade, eles conseguiram alcançar êxito e enfrentar tais problemas.

A questão de gênero surgiu durante a pesquisa de campo sendo uma categoria que foi tratada no escopo do trabalho, pois faz parte da trajetória desses sujeitos, que são em sua maioria do sexo feminino. Tal problemática surgiu em vários momentos da pesquisa e discutíla se faz necessário, pois a desigualdade de maneira geral aflige as mulheres, sobretudo as que ainda vivem em regiões interioranas do país e que convivem com uma visão bastante conservadora no que diz respeito ao papel da mulher, visão esta que é alimentada pela falta de oportunidades e pelo pouco acesso à educação nessas regiões. 
A respeito da perspectiva de Longevidade Escolar, conclui-se que os egressos estão motivados para continuar seus estudos de maneira a alcançar um futuro melhor e ter um bom desempenho como professores, por meio de aperfeiçoamento e pós-graduações.

Em Carinhanha, a modalidade de educação a distância é viável, mesmo com uma estrutura que requer ainda melhorias, reformas e ações para que possa oferecer um atendimento mais adequado aos estudantes. Um dos sujeitos pesquisados destacou que não vê "distância na educação a distância". No entanto, é importante ressaltarmos que existem outras pesquisas que apontam dados diferentes. Schneider (2013, p. 183) ilustra o desconforto dos estudantes a partir de uma fala de um dos sujeitos de sua pesquisa: "Eu aprendi muito com os cursos, com as disciplinas, perto do que eu sabia antes, hoje sou outra pessoa, mas eu vejo a educação a distância muito distante, pois aprendi mais tive que correr atrás”.

Os dados do trabalho citado trazem uma realidade que também se faz presente e necessita ser discutida. Tem-se uma UAB que precisa de reformas, melhorias e até mesmo de uma proposta de modelo pedagógico mais coerente, que instigue o pensamento crítico, emancipador, desenvolvendo no educando a percepção da existência de perspectivas diferentes das hegemônicas. Ou seja: a democratização do ensino na modalidade da EAD não deve servir apenas como fator quantitativo; seu alcance deve ser também qualitativo.

A educação a distância é necessária, apesar de todos os problemas que necessitam ser equacionados. Os alunos participantes da pesquisa enxergavam na modalidade uma oportunidade que obtiveram para modificar suas vidas de maneira significativa. Essa modalidade, no entanto, ainda aponta para a existência de um sistema frágil, devido, sobretudo, a uma política que foi gerada em meio a muitas turbulências e visões não muito claras sobre o papel da educação e da educação a distância na modificação de trajetórias individuais e de toda uma localidade. Esse modelo de ensino necessita, portanto, de reformas e melhorias para que a política da Universidade Aberta do Brasil consiga se efetivar como uma modalidade que eleve o pensamento crítico, contribuindo, assim, para o despertar do educando quanto a sua propria situação social e o seu lugar no mundo. 


\section{REFERÊNCIAS BIBLIOGRÁFICAS}

ALMEIDA, Ivan C. Gastos com Educação no Período de 1994 a 1999. Revista Brasileira de Estudos Pedagógicos. V82. n. 200, 201, 202, jan. - dez 2001.

AIRES, Carmenísia Jacobina. Planejamento e Gestão Escolar. PEDEaD, módulo VI, Brasília: Universidade de Brasília, 2009.

ARAÚJO, Verônica Danieli Lima, GLOTZ Raquel Elza Oliveira. O letramento digital enquanto instrumento de inclusão social e democratização do conhecimento: Desafios atuais. Revista Científica de Educação a Distância, v. 2, junho, 2009. Disponível em: $<$ revistapaideia.unimesvirtual.com.br/index.php?journal=paideia\&page=article\&op=view File\&path[]=85\&path[]=50>. Acesso em: ag. de 2012.

AGUIAR, Marcelo y ARAÚJO, Carlos Henrique. BOLSA-ESCOLA Educación para enfrentar la pobreza - Brasília : UNESCO, 2002.

ALVES, L. A. DE A. Distribuição de renda no estado da Bahia: algumas considerações sobre as áreas analisadas. Aspectos sociais das desigualdades na Bahia. Salvador: SEI, 2008 .

BANDERA, Nicolau Dela. Esforçados e "talentosos": a produção do sucesso escolar na Escola Técnica Federal de São Paulo. Educ. rev. vol.30 no.3 Belo Horizonte July/Sept. 2014 Epub July 25, 2014.

BRASIL. Lei $\mathbf{n}^{\circ}$ 9394, de 20 de dezembro de 1996. Estabelece as diretrizes e bases da educação nacional.Disponível em: <http://www.mec.gov.br>. Acesso em: jan. de 2014.

BRASIL. Decreto no 5.800, de 8 de junho de 2006. Dispõe sobre o sistema Universidade Aberta do Brasil - UAB. Disponível em: 〈http://www.mec.gov.br>. Acesso em: jan. de 2014.

BRASIL. Conselho Nacional de Educação (CNE). Parecer CNE/CP 009/2001. Proposta de diretrizes para a formação inicial de professores da educação básica em cursos de nível superior. 2001. Disponível em: 〈www.mec.gov.br〉. Acesso em: jan. de 2014.

BELTRÃO, K.I; ALVES, J.E.D. A reversão do hiato de gênero na educação brasileira no século XX. ABEP,2004. Disponível em:< http://www.metas2015.unb.br/Documentos/Educa cao\%20Universal/Reversao\%20do\%2 0hiato\%20de\%20genero\%20na\%20educacao.pdf. > Acesso em: fev. de 2014.

BRITO, Eliana Povoas Pereira Estrela. Políticas Públicas de Formação e a UAB: Que arquitetura é essa. ESUD 2013 - X Congresso Brasileiro de Ensino Superior a Distância Belém/PA, 11-13 de junho de 2013 - UNIREDE. Disponível em: <http://www.aedi.ufpa.br/esud/trabalhos/poster/AT1/113279.pdf>. Acesso em: jan. de 2014.

BOURDIEU, Pierre. O poder simbólico. Lisboa: Difel/Rio de Janeiro: Bertrand Brasil, 1989. A reprodução. Rio de Janeiro: Francisco Alves, 1992. 
A escola conservadora: as desigualdades frente à escola e à cultura. file:///C:/Users/Sergio/Downloads/Boudieu_escola\%20conservador\%20(1).pdf. Acesso em: jan. de 2015.

. Escritos de educação. Petrópolis: Vozes, 1998.

. A Miséria do Mundo. Petrópolis: Vozes, 2007.

CASTELLS, Manuel. A era da informação: economia, sociedade e cultura. Tradução de Roneide V. Majer. São Paulo: Paz e Terra, 1999.

CHAVES, E. Conceitos Básicos: Educação a Distância. EdutecNet: Rede de Tecnologia na Educação, 1999. Disponível em: http://www.edutecnet.com.br/. Acesso em: 02 de março de 2014.

CHERON, Cibele; EPPING, Léa. Trabalho, Gênero, Raça e Pobreza na Região Metropolitana de Porto Alegre: Análise da realidade e alternativas para modificá-la. SOCIOLOGIA \& POLÍTICA. I Seminário nacional em política e sociologia, UFPR, Paraná, 2009. Disponível em: $\quad<$ http://www.humanas.ufpr.br/site/evento/SociologiaPolitica/GTsONLINE/GT5\%20online/EixoII/trabalho-genero-raca-CibeleCheron.pdf > Acesso em: dez. de 2013.

DIAS, Rosilânia Aparecida; LEITE, Lígia Silva. Educação à distância: da legislação ao pedagógico. Petrópolis: Vozes, 2010.

ENNAFAA, Ridha. As desigualdades sociais na educação: o exemplo da educação superior brasileira.Revista Pedagógica - UNICHAPECÓ - Ano -16 - n. 29 vol. 02 - jul./dez. 2012.

FAIRCLOUGH, Norman. Language and power. New York: Longman, 1989.

FLICK, Uwe. Desenho da pesquisa qualitativa. Porto Alegre: Artmed, 2009.

FRIEDMANN, John. Empowerment: uma política de desenvolvimento alternativo. Oeiras: Edições Celta, 1996.

FREIRE, Paulo. Pedagogia da esperança: um reencontro com a pedagogia do oprimido. Rio de Janeiro: Paz e Terra, 1992.

FUNAG - Fundação Alexandre de Gusmão. AS 15 MAIORES ECONOMIAS DO MUNDO (EM PIB E PIB-PPP). http://www.funag.gov.br/ipri/index.php/equipe/47informacoes/94-as-15-maiores-economias-do-mundo-em-pib-e-pib-ppp. Acesso em Jan. 2015.

GATTI, Bernadete, ESPOSITO, Yara L., SILVA, Rose Neubauer da. Características de professores(as) de $1^{\circ}{ }^{\circ}$ grau no Brasil : perfil e expectativas . Educação \& Sociedade, v. 15, ago. 1997. Disponível em: <www. Unemate-net.br. Acesso em: set. de 2012.

GIL, Antonio Carlos. Métodos e técnicas de pesquisa social. São Paulo: Atlas, 1999.

Como elaborar projetos de pesquisa. 4. ed. São Paulo: Atlas, 2008. 
GOMES, Silvane Guimarães Silva. EVOLUÇÃO HISTÓRICA DA EAD.e-Tec Brasil Tópicos em Educação a Distância. Módulo 2, 2008. Disponível em: <http://ftp.comprasnet.se.gov.br/sead/licitacoes/Pregoes2011/PE091/Anexos/Eventos_modulo _I/topico_ead/Aula_02.pdf >.Acesso em: fev. de 2014.

GONSALVES, Elisa Pereira. Conversas sobre iniciação à pesquisa científica. $4^{\mathrm{a}}$ ed. Campinas: Alínea, 2007.

GONZALEZ, Mathias. Fundamentos da tutoria em educação à distância. São Paulo: Avercamp, 2005.

Instituto Brasileiro de Geografia e Estatística - IBGE. Primeiros resultados definitivos do Censo 2010: população do Brasil é de 190.755.799 pessoas. Disponível em: <http:// www.ibge.gov.br/home/presidencia/noticia/populacao-do-Brasil-e-de-190.755.799-pessoas > 2011. Acesso em: set. de 2012.

Instituto de Pesquisas Econômicas Aplicadas - IPEA. Retrato das desigualdades de gênero e raça. Disponível em: http://www.ipea.gov.br/retrato/pdf/revista.pdf. Acesso em: jan. de 2015.

KUHN, ANA PAULA. PRÁTICAS AVALIATIVAS DE EGRESSOS DO CURSO DE PEDAGOGIA A DISTÂNCIA DA UFMT: IMPLICAÇÕES DA FORMAÇÃO INICIAL E O EXERCÍCIO DE SER PROFESSOR. Dissertação de mestrado, 2012. Disponível em: www.ie.ufmt.br/ppge/dissertacoes/index.php?op=download\&id=392. Acesso em: jun. 2015.

LAHIRE, Bernard. Sucesso Escolar nos Meios Populares: as razões do improvável. São Paulo: Ática, 1997.

LA MENDOLA, Salvatore. O sentido do risco. Tempo social: revista de sociologia da USP. São Paulo, v. 17 n. 2, nov. 2005.

LACÉ, Andréia Mello. Da ideia de Universidade Aberta à sua implementação como política pública no Brasil (1971-2006). Faculdade de Educação; Universidade de Brasília, tese de doutorado, 2014.

Homem Plural: Os determinantes da ação. Petrópolis: Vozes, 2002.

LÉVY, Pierre. Cibercultura. São Paulo: Editora 34, 1999.

LIBÂNEO, José Carlos. Democratização da Escola Pública. A pedagogia crítico-social dos conteúdos. Edições Loyola, 2008 (coleção educar I)

LISBOA, Teresa Kleba. Empoderamento de mulheres e participação na gestão de políticas públicas. In: Anais II Seminário Nacional Movimentos Sociais, Participação e Democracia. Florianópolis, 2007.

LOPES, Ruth; LISNIOWSKI, Simone; JESUS, Girlene. Políticas Públicas de Educação Superior à Distância: um estudo de evasão em curso de Pedagogia à distância oferecido no âmbito do sistema Universidade Aberta do Brasil. Reuni, 2011. 
MADSEN, Nina. A construção da agenda de gênero no sistema educacional brasileiro (1996 - 2007). Dissertação (Mestrado em Sociologia). Departamento de Sociologia. Universidade de Brasília - UnB. Brasília, 2008.

MORAN, José Manuel. Modelos do Ensino Superior a Distância no Brasil. Sumare, Revista Acadêmica Eletrônica. Disponível em: $\langle$ http://dev.sumare.edu.br/Arquivos/1/raes/01/raesed01_artigo06.pdf $>$. Acesso em: jan. de 2013.

MILLS, C. Wright. A imaginação sociológica. 4.ed. Rio de Janeiro: Zahar, 1975.

NOGUEIRA, Conceição. Análise do Discurso. Métodos e técnicas de avaliação: novos contributos para a prática e investigação. Braga: CEEP. Disponível em: http:<//repositorium.sdum.uminho.pt/bitstream/1822/4355/1/Capitulo_analise\%20do\%20disc urso_final1.pdf>. Acesso em: out. de 2013.

NASCIMENTO, Eduardo. Jovens e educação superior: as aspirações de cursos prévestibulares populares. Dissertação (Mestrado em Educação). Faculdade de Educação da Universidade de São Paulo. São Paulo, 2009. Disponível em :file:///C:/Users/Sergio/Downloads/EduardoPeterledoNascimento\%20(2).pdf. Acesso em jan. 2015.

OTRANTO, Célia Regina. Concepção e Organização da Educação Superior: novas propostas, velhas idéias. Mesa Redonda: Concepção e Organização da Educação Superior - Eixo Temático: Organização da Educação Nacional - $5^{\circ}$ Congresso Nacional de Educação (5 ${ }^{\circ}$ CONED) - 5/2004 - Recife, PE.

PASTORE, José. O trabalho da mulher. O Estado de S. Paulo, 2007.Disponível no site: $<$ http://www.josepastore.com.br/artigos/mu/mu_002.htm $>$. Acesso em: fevereiro de 2014.

PERRENOUD, Philipe. Formação contínua e obrigatoriedade de competências na profissão de professor. Sistema de avaliação educacional. São Paulo: FDE, 1998.

PETERS, Otto. A educação a distância em transição. Tendências e desafios. São Leopoldo: Editora Unisinos (2004).

PEREIRA, Potyara Amazoneida. Centralização e exclusão social: duplo entrave à Política de Assistência Social. Revista do Programa de Pós-Graduação em Política Social do Departamento de Serviço Social da Universidade de Brasília, nº 3, jul. a set. de 1998.

PIOVESAN, Flavia. Direitos Humanos, Civis e Políticos: A conquista da cidadania feminina. O progresso das mulheres no Brasil 2003-2010. Rio de Janeiro: CEPIA; Brasília: ONU $\quad 2011 . \quad$ Mulheres, Disponível em $:<$ http://www.senado.gov.br/atividade/materia/getPDF.asp?t=108224\&tp=1>. Acesso em: fevereiro de 2014.

PONTES, Elício. A comunidade de trabalho e aprendizagem em rede (CTAR) na Faculdade de Educação da UnB. In: SOUZA, Amaralina Miranda de; FIORENTINI, Leda Maria Rangearo \& RODRIGUES, Maria Alexandra Militão. (Orgs.) Educação Superior a Distância: Comunidade de Trabalho e Aprendizagem em Rede- CTAR. Brasília: Editora da UnB, 2009. 
PORTES, Écio Antônio. Trajetórias e estratégias escolares do universitário das camadas populares. Dissertação (Mestrado em Educação). FAE/UFMG. Belo Horizonte, FAE/UFMG, $1993 . \quad$ Disponível http://www.bibliotecadigital.ufmg.br/dspace/bitstream/handle/1843/FAEC84NQZ9/2000000028.pdf?sequence=1. Acesso em: dez. de 2014.

Relatório do desenvolvimento humano 2011. Anexo Estatístico. Disponível em: <http://hdr.undp.org/en/media/HDR_2011_PT_Tables.pdf>. Acesso em: setembro de 2012.

RESENDE, Viviane de Melo \& RAMALHO, Viviane. Análise de Discurso Crítica. 2 ed., $1^{\circ}$ reimpressão - São Paulo: Contexto, 2013.

RODRIGUES, Rosângela Schwarz. Modelo de avaliação para cursos no ensinoa distância: estrutura, aplicação e avaliação. Dissertação de mestrado - Universidade Federal de Santa Catarina, Florianópolis, $1998 . \quad$ Disponível em: <http://www.eps.ufsc.br/disserta98/roser/index.htm>. Acesso em outubro de 2013.

SANTOS, Fabiano Cunha dos. UAB como política pública de democratização do ensino superior via EAD. Disponível http://www.anpae.org.br/simposio2011/cdrom2011/PDFs/trabalhosCompletos/comunicacoes Relatos/0184.pdf. Acesso em: Jan. de 2015.

SANTOS, Lázaro. Implicações de um curso a distância a formação humana de professores: um estudos sobre egressos de graduação em Pedagogia da UERJ. Trabalho de Dissertação, 2009. Disponível em http://www.bdtd.uerj.br/tde_busca/arquivo.php?codArquivo=3605. Acesso em: Jan. 2015.

SANTOS, Honorato Ribeiro dos. Carinhanha de ontem e de hoje. Editora Carrancas do Rio São Francisco, $5^{\circ}$ volume, 2007.

SANCHO, Juana Maria; HERNÁNDEZ, Fernando. Tecnologias para transformar a educação. Tradução de Valério Campos. Porto Alegre: Artmed, 2006.

SETTON, Maria da Garça Jacintho. Um novo capital cultural: pré-disposições e disposições e disposiões à cultura informal nos segmentos com baixa escolaridade. Educação e Sociedade, Campinas, VOL. 26 n. 90, Jan./Abr. 2005. Disponível em: 〈http://www.scielo.br/pdf/\%0D/es/v26n90/a04v2690>. Acesso em: set. de 2012.

SETTON, M. G. J. A Divisão interna do campo universitário: uma tentativa de classificação. Revista brasileira de estudos pedagógicos, Brasília, v.80, n.196, p.451-471, set./dez. 1999.

SCHNEIDER, Magalis Bésser Dorneles. Os processos comunicacionais na política de formação de professores a distância. Tese (Doutorado em Educação) - Universidade de Brasília, Brasília, 2013.

SILVA, J. S. Por que uns e não outros? Caminhada de estudantes da Maré para a universidade. Tese (Doutorado em Educação). Pontifícia Universidade Católica. Rio de Janeiro, 1999. 
SILVA, Elizângela Samara da. As entrelinhas da inclusão/exclusão social na atualidade: uma discussão conceitual. Disponível em: http:<//www.joinpp.ufma.br/jornadas/joinpp2011/CdVjornada/JORNADA_EIXO_2011/DES IGUALDADES_SOCIAIS_E_POBREZA/AS_ENTRELINHAS_DA_INCLUSAO_EXCLU SAO_SOCIAL_NA_ATUALIDADE_UMA_DISCUSSAO_CONCEITUAL_.pdf. $\quad$ Acesso em: fev. de 2014.

SOUZA, José Evangelista de. CORONEIS NO MEDIO SÃO FRANSCISCO FATOS E HISTÓRIAS. Editora de Jovens Assistentes Sociais de Santana - AJASS, 1981.

SORJ, Bernardo. brasil@ povo.com: a luta contra a desigualdade na sociedade da informação. Rio de Janeiro: Jorge Zahar; Brasília: Unesco, 2003.

Triviños, Augusto N.S. Introdução à pesquisa em ciências sociais: a pesquisa qualitativa em educação: 1.ed. São Paulo: Atlas, 1987.

VALENTE, J. A.; BUSTAMANTE, Silvia B. Vidal. Educação a Distância: prática do profissional reflexivo. São Paulo: Avercamp, 2009;

VALENTE, J. Educação a Distância: criando abordagens educacionais que possibilitam aconstrução de conhecimento. In: ARANTES, V. A. (Org.). Educação a distância: pontos e contrapontos. São Paulo: Summus, 2011.

WERTHEIN, Jorge. A sociedade da informação e seus desafios. Revista Ci. Inf., Brasília, v. 29, n. 2, p. 71-77, maio/ago. 2000. Disponível em: http://revista.ibict.br/ciinf/index.php/ciinf/article/viewFile/254/1705. Acesso janeiro de 2014.

ZUIN, Antonio A. S. Educação a distância ou educação distante. Disponível em: http://www.scielo.br/pdf/es/v27n96/a14v2796.pdf. Acesso em: jan. 2015. 


\begin{abstract}
APÊNDICE 1
Roteiro para a entrevista narrativa:

1-Ressalte quais foram as maiores dificuldades presentes em sua trajetória acadêmica durante o curso.
\end{abstract}

2-Fale sobre quais foram seus desafios quanto à leitura e escrita acadêmica exigida no decorrer do curso e como você se articulava para lidar com as dificuldades presentes.

3- A respeito dos desafios ligados ao aspecto tecnológico, diga como você manejava as tecnologias em prol de sua aprendizagem e quais estratégias você utilizou para lidar com esses desafios.

4-Fale a respeito das condições sociais e educacionais da cidade de Carinhanha.

5-Como você se sente vivendo em Carinhanha?

6- Você gostaria viver diferente de como vive atualmente? E continuaria morando em Carinhanha? Por quê?

7- A desigualdade social está presente na cidade de Carinhanha e no seu dia a dia? Se sim, de que forma?

8- Na sua visão, quais os fatores que mais contribuem para a manutenção da desigualdade social do país?

9- Em algum momento o fator econômico chegou a ameaçar ou interferir para que você continuasse o curso? Se sim, de que forma?

10- Como Carinhanha enxerga o polo UAB? Qual o entendimento que a cidade tem sobre o polo?

11- Como você avalia a infraestrutura do pólo no que diz respeito às instalações e aos aparatos físicos oferecidos?

12- Explique como foi o seu relacionamento com colegas, tutores e professores durante o curso.

13- Quem você considera como determinante para você ter concluído o curso de graduação em Pedagogia pela UnB/ UAB? 
14- Você pretende dar continuidade aos seus estudos futuramente? Diga como isso acontecerá?

15- Em sua opinião, quais fatores que mais contribuíram para a conclusão de seu curso em pedagogia?

16- O que significa um diploma de nível superior para você?

17- O que você mudaria no modo como o curso de Pedagogia a distância da UnB/UAB funciona atualmente?

18- Fale livremente sobre o significado que o curso de Pedagogia FE/UnB - UAB tem em sua vida. 


\section{APÊNDICE 2}

\section{QUESTIONÁRIO}

Este questionário é parte integrante do meu projeto de pesquisa. Gostaria de pedir a colaboração dos participantes para que respondessem as questões abaixo. Agradeço muito a colaboração de vocês, que são essenciais na realização da minha pesquisa.

Marque um (X) na afirmativa que corresponde com o seu perfil:

1- Seu sexo:

( ) Feminino

( ) Masculino

2- Sua idade:

( ) 18 a 25

( ) 26 a 33

( ) 34 a 40

( ) 41 a 48

( ) 49 a 55

( ) acima de 55

3-Você já atua como professor:

( ) Sim

( ） Não

Se sim, há quanto tempo?

4- Marque de acordo com sua renda familiar:

( ) 1 salário mínimo 
( ) 2 salários mínimos

( ) 3 salários mínimos

( 4 salários mínimos

( ) Acima de 4 salários mínimos

Tendo como base que 1 salário mínimo equivale atualmente a $\mathrm{R} \$ 724,00$ reais.

5- Você tem filhos? Se sim, quantos?

6- Você é casado ou solteiro?

( ) casado

( ) solteiro

7- Já atua como professor?

( ) $\operatorname{sim} \quad(\quad)$ não

8- Marque se você atua como docente na rede pública, privada ou nas duas instituições educacionais, pública e privada, concomitantemente:

( ) pública

( ) privada

( ) Atuo como docente tanto na rede pública como privada 
9-Quais fatores te levaram a fazer um curso à distância?

10- Em sua opinião, quais os fatores que mais contribuíram para a conclusão de seu curso em pedagogia?

11-O que você indicaria como aspectos que contribuíram para que você chegasse até o nível superior? 
12- Quais foram as maiores dificuldades em sua vida que dificultaram seu processo educacional?

13- Como você avalia o diploma que receberá e qual o sentido que ele tem para você? 
14- Você pretende ou não cursar outra graduação, ou fazer outro tipo de curso, ou ainda pretende cursar uma pós-graduação, dando continuidade a estudos por meio de uma especialização, mestrado ou doutorado?

15- Por que você acredita ser importante o diploma de nível superior e o que isso significa para você? 


\section{APÊNDICE 3}

\section{ROTEIRO ENTREVISTA NARRATIVA (2)}

1- Você sempre estudou em escola pública ou cursou alguma série em uma instituição particular de ensino?

2- Como era sua relação familiar no que diz respeito aos estudos? Você era estimulado pelos seus familiares?

3- Em que idade você começou a trabalhar e como se dava sua relação entre o trabalho e o estudo?

4- Onde aconteceu sua educação básica de primeiro ao quinto ano e quais foram as suas maiores dificuldades?

5- E o seu ensino fundamental de quinto ao nono ano? Fale sobre como se deu essa escolarização e se você encontrou alguma dificuldade nesse percurso.

6- Sobre o ensino médio: você acredita que foi importante para você, te estimulando a realizar o ensino superior e te ajudando a passar no vestibular?

7- Sobre o ensino superior: diga quais foram as maiores dificuldades enfrentadas nesses 4 anos que possam ter atrapalhado o seu desempenho no decorrer do curso.

8- Você já tinha tido algum contato com a educação a distância antes?

9- Você já tinha acesso a computador e já entendia como um curso a distância funcionava?

10- Você teve apoio da UAB durante o curso (infraestrutura do pólo, professores, tutores e colegas)?

11- Como Carinhanha enxerga a UAB? Qual o entendimento que a cidade tem sobre o polo?

12- Você considera que a infraestrutura do polo é boa? Teve alguma dificuldade ligada aos aparatos físicos durante o curso?

13- Fale sobre o ambiente virtual do curso. Você acredita que ele promoveu suas aprendizagens de maneira significativa? 
14- Fale sobre como é a sua relação familiar. Você recebe apoio para estudar, sendo estimulado de alguma maneira?

15- Diga quais são os principais desafios sociais e econômicos no âmbito deCarinhanha que estiveram presentes no transcorrer de sua trajetória acadêmica até os dias de hoje.

16- Sobre o diploma que irá receber, você acredita que ele será importante em quais áreas da sua vida?

17- Quais fatores de sua vida que te ajudaram a chegar até o nível superior? Como você conseguiu atingir sucesso em sua trajetória acadêmica?

18- Fale livremente sobre qualquer tema que você acredita que enriqueceria esta entrevista. 


\section{APÊNDICE 4}

\section{TERMO DE CONSENTIMENTO}

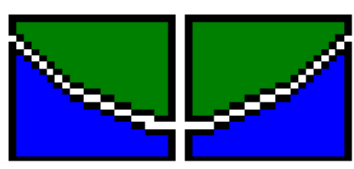

Universidade de Brasília

Faculdade de Educação

Programa de Pós-Graduação em Educação

TERMO DE CONSENTIMENTO LIVRE E ESCLARECIDO

Dados de identificação

Título do Projeto: FORMANDOS DO CURSO DE PEDAGOGIA À DISTÂNCIA: TRAJETÓRIAS, CONDIÇÕES DE VIDA NO LUGAR E PERSPECTIVAS DA LONGEVIDADE ESCOLAR

Pesquisador Responsável: Beatriz Helena Pinho Silva, sob a orientação do Prof. Dr. Carlos Alberto Lopes de Sousa.

Instituição a que pertence a Pesquisadora Responsável: Faculdade de Educação da Universidade de Brasília - UnB.

Senhor

$\left({ }^{a}\right)$,

RG

Órgão

Expedidor

O Senhor $\left({ }^{a}\right)$ está sendo convidado

(a) a participar do projeto de pesquisa, FORMANDOS DO CURSO DE PEDAGOGIA À DISTÂNCIA: TRAJETÓRIAS, CONDIÇÕES DE VIDA NO LUGAR E PERSPECTIVAS DA LONGEVIDADE ESCOLARe seu orientador de responsabilidade do pesquisador Beatriz Helena Pinho Silva e seu orientador Prof. Dr. Carlos Alberto Lopes de Sousa.Tendo como finalidade Analisar Investigar os fatores pedagógicos, sociais, econômicos e culturais que 
favorecem a conclusão do curso de pedagogia oferecido pela Universidade de Brasília em pareceria com a Universidade Aberta do Brasil em Carinhanha - BA.

O Senhor $\left({ }^{a}\right)$ tem liberdade de se recusar a participar e ainda se recusar a continuar participando em qualquer fase da pesquisa, sem qualquer prejuízo. Sempre que quiser poderá pedir mais informações sobre a pesquisa através do telefone do pesquisador do pesquisador (61) 8318-0802.

A participação nesta pesquisa não traz complicações legais. Nenhum dos procedimentos usados oferece riscos à sua dignidade. Todas as informações coletadas neste estudo são estritamente confidenciais. Somente o pesquisador e o orientador terão conhecimento dos dados.

Ao participar desta pesquisa o Senhor $\left({ }^{a}\right)$ não terá nenhum benefício direto. Entretanto, esperamos que este estudo traga informações importantes sobre o tema estudado. $\mathrm{O}$ pesquisador se compromete a divulgar os resultados obtidos. As informações fornecidas pelo senhor $\left({ }^{a}\right)$ serão utilizadas somente para fins de pesquisa e outros trabalhos acadêmicos, inclusive em coautoria ou por outros pesquisadores interessados na temática, garantindo o anonimato do(a) entrevistado(a).

O Senhor $\left({ }^{a}\right)$ não terá nenhum tipo de despesa para participar desta pesquisa, bem como nada será pago por sua participação.

$\mathrm{Eu}$, declaro ter sido informado e concordo em participar, como voluntário, do projeto de pesquisa acima descrito.

Carinhanha - BA, de de 
ANEXO 1

FOTOS DE CARINHANHA

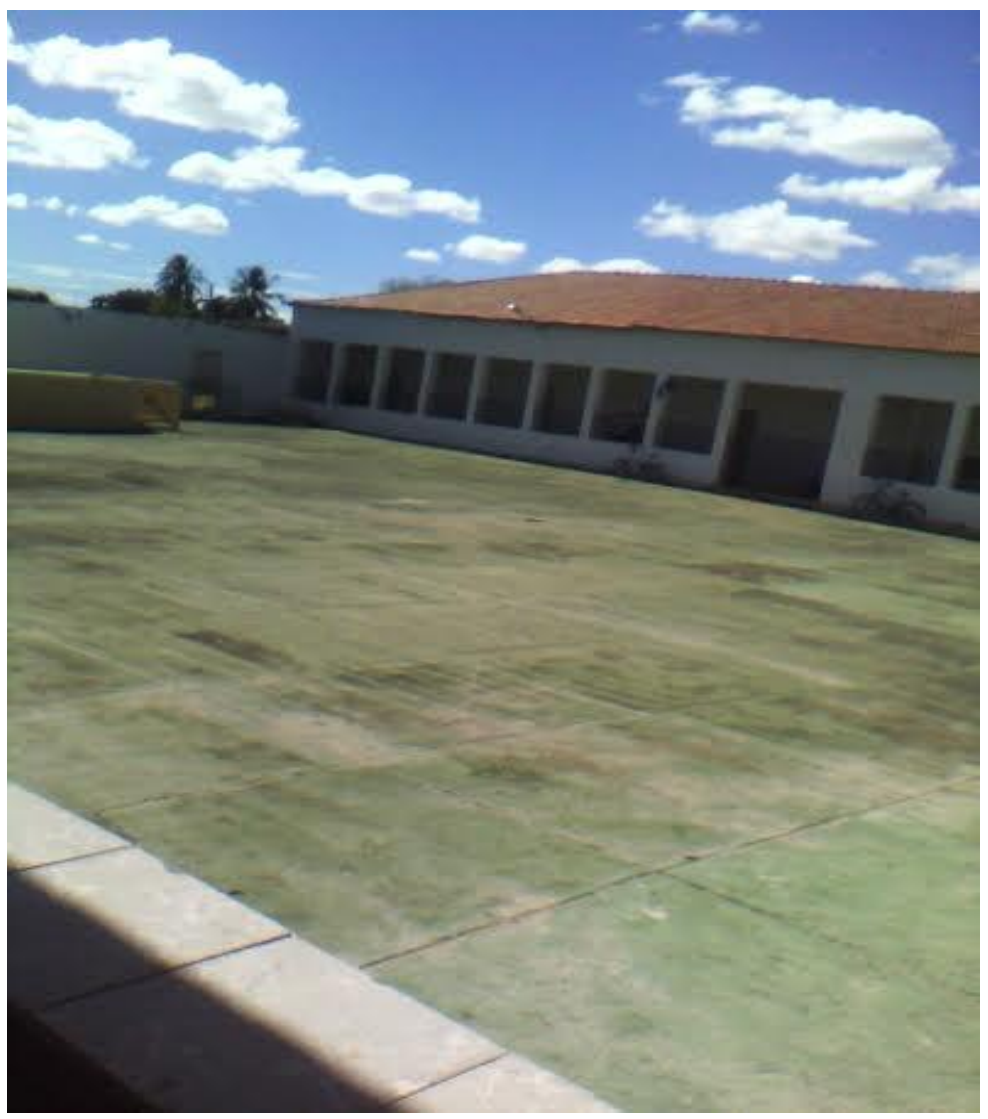

Foto 1: Fachada do polo da Universidade de Brasília em Carinhanha - BA.

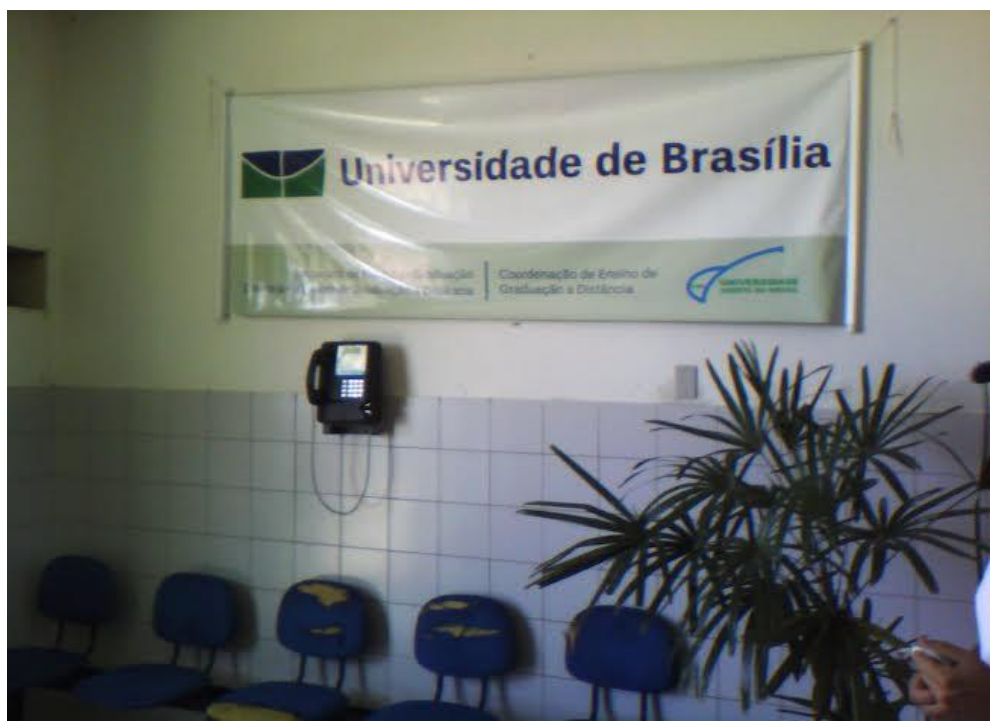

Foto 2: Entrada do saguão do polo que dá acesso às salas de aula. 


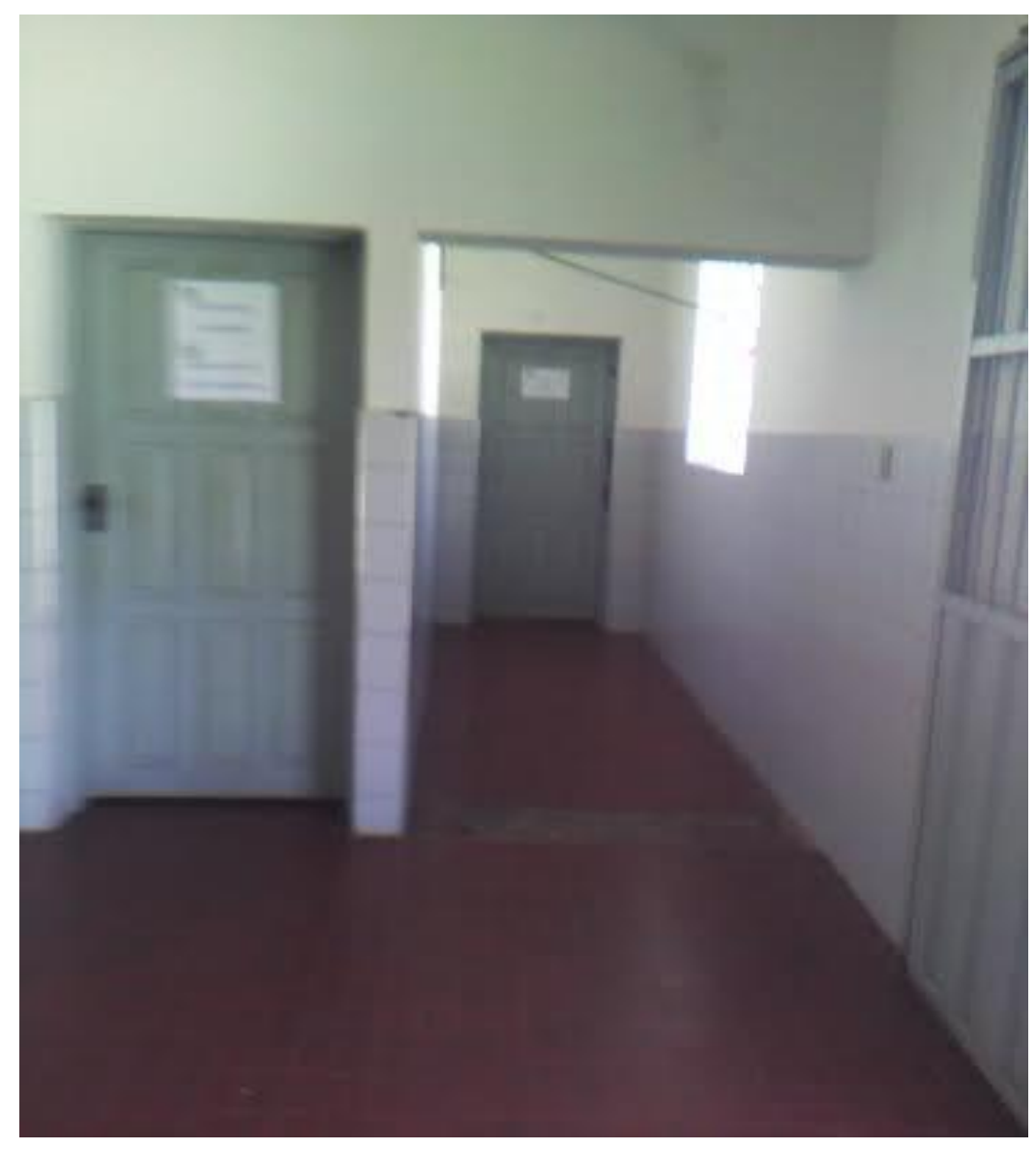

Foto 3: Salas de aula onde acontecem os encontros presenciais.

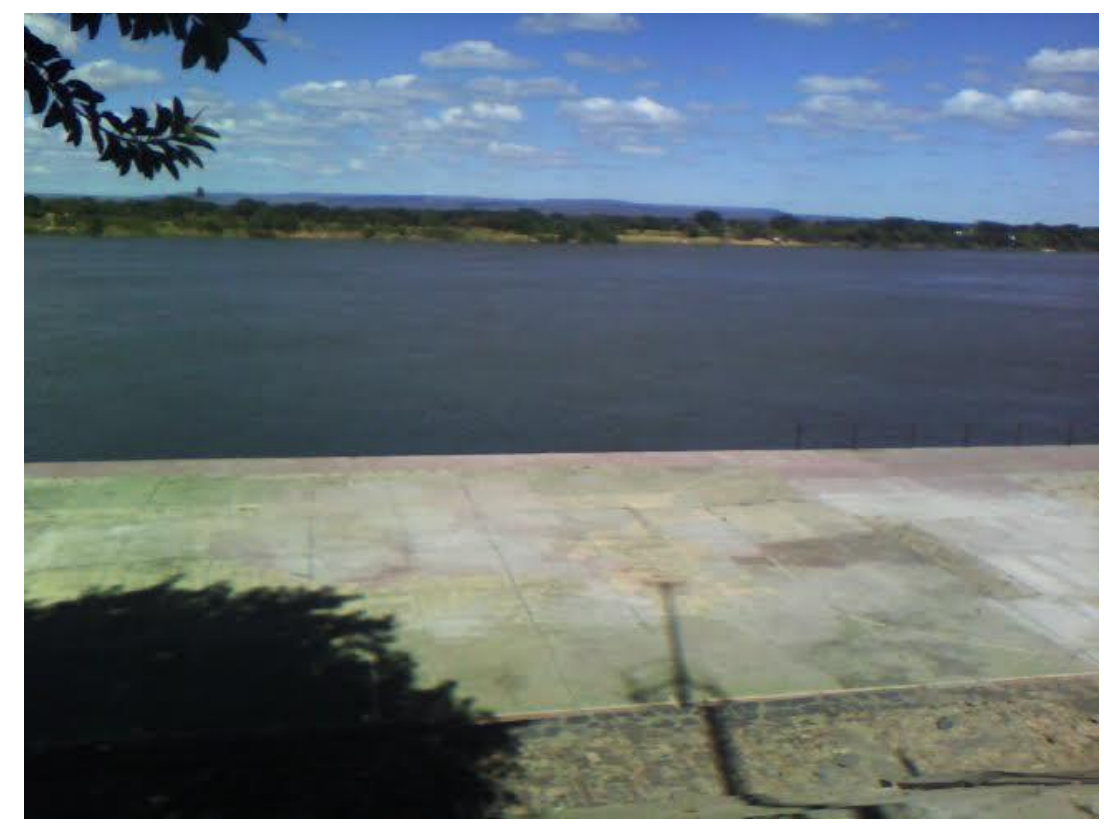

Foto 4: Rio que corta a cidade de Carinhanha - Rio São Francisco. 